\title{
THE DEVELOPMENT OF AFRICAN HISTORY AS A DISCIPLINE IN THE ENGLISH-SPEAKING WORLD:
}

\section{A STUDY OF ACADEMIC INFRASTRUCTURE}

Craig Watterson

A thesis submitted in fulfilment of the requirements for the degree of Master of Arts at Victoria University of Wellington 


\section{Table of Contents}

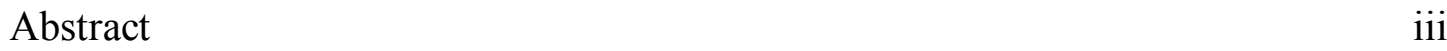

Acknowledgements $\quad$ iv

Tables

Abbreviations

Introduction 1

Chapter One $\quad$ The Development of African History, 1787-1948: 8 The Evolution of British African Universities

Chapter Two The Establishment of an Academic Infrastructure for 31 African History in the United Kingdom

Chapter Three African History in the United States 59

Chapter Four Sources and Historiography: Charting the Pre-Colonial 83 African Past, 1450-1800

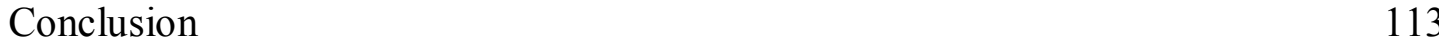

$\begin{array}{lr}\text { Appendix One } & 119\end{array}$

$\begin{array}{ll}\text { Bibliography } & 120\end{array}$ 


\begin{abstract}
This thesis examines the infrastructure behind the academic discipline of African History. By looking at government reports, a selection of reflective essays and memoirs written by key historians, and the key pre-colonial sources that have driven select studies, my thesis explains how African History emerged in British and U.S. universities. Key factors include the English colonisation of Sierra Leone in 1787, the affiliation of Fourah Bay College with the University of Durham in 1876, and the creation of universities in 1948 in Nigeria, Sudan, Uganda and Ghana. In Britain, the importance of African territories resulted in a series of influential reports that shifted missionary controlled education on the African continent to colonial government control. After 1945 a series of pivotal government reports established the impetus and funding for the academic institutionalisation of African History in the United Kingdom. The influence of an English academic recognition of African History provided a transnational current of ideas that flowed between Africa and the United Kingdom, and from there to the United States. With the advent of the Cold War the United States recognised the importance of developing Area Studies programmes, including African Studies, and during the 1960s and 1970s became world leaders in the field. Crucial to this development was the role of pioneering historians who travelled to Africa to teach and research, and who then returned to train a new generation of Africanists. Africanist scholars, recognising the importance of African agency, expanded the shape of the discipline through investigation of oral sources and reexamination of extant pre-1800 European written records. 'Charter historians' established university programmes that would produce scholars with the necessary skills required to sustain the new discipline. The infrastructure that under-girded and positioned African History in the mainstream of academia is analysed in-depth, and is, as such, the central theme of this thesis.
\end{abstract}




\section{Acknowledgements}

I would like to thank my supervisor Steve Behrendt whose help and guidance were instrumental factors in my completion of this thesis. My thanks also go to my fellow students Vivian Rodríguez, Nick Radburn and Karen Cheer for their support during my studies. Other members of the History Programme have supplied valuable help, particularly Jane Fogden and Professor Sekhar Bandyopadhyay. I would also like to thank historians David Henige, Adam Jones, John Thornton, David Northrup, Robin Law and Janet Ewald for taking the time to correspond with me, and Ruth Finnegan who helped me locate details for Robin Horton. My gratitude also goes to my friends, family and especially to my wife Maree for encouraging me to study in the first place, her constant reading of my drafts, and her steady support. 


\section{Tables}

$\begin{array}{ll}\text { Table } 1 & 37\end{array}$

Table $2 \quad 49$

$\begin{array}{lr}\text { Table } 3 & 65\end{array}$

$\begin{array}{ll}\text { Table } 4 & 73-74\end{array}$

$\begin{array}{lr}\text { Table } 5 & 85\end{array}$

$\begin{array}{ll}\text { Table } 6 & 87\end{array}$

Table A1, Appendix A 119 
Abbreviations

$\begin{array}{ll}\text { ASA } & \text { African Studies Association } \\ \text { CAC } & \text { Colonial Advisory Committee } \\ \text { CMS } & \text { Church Missionary Society } \\ \text { CWAS } & \text { Centre of West African Studies, University of Birmingham } \\ \text { IRSAC } & \text { Institute for Research in Central Africa, Belgium } \\ \text { NDEA } & \text { The National Defence Education Act P.L. 85-864 } \\ \text { OHBE } & \text { Oxford History of the British Empire, multivolume series } \\ \text { SOAS } & \text { School of Oriental and African Studies, University of London } \\ \text { SOS } & \text { School of Oriental Studies, University of London } \\ \text { SSRC } & \text { Social Science Research Council } \\ \text { UN } & \text { United Nations }\end{array}$




\section{INTRODUCTION}

The year 2007 marked a milestone in the history of Africa. Two hundred years had passed since the abolition of the slave trade by the British Parliament. This year also occasioned the fiftieth anniversary of the independence of Ghana, the first African state to be granted independence by the British. Between 1957 and 2007, Africans have witnessed the independence of all former European colonies, including the end of Apartheid and the beginnings of democracy in South Africa in 1994. Today, in 2008, African History is an accepted scholarly discipline in Britain and the United States. The journey of African History's development to formal academic acceptance marks a fundamental shift in attitude from an Africa with no past to an Africa with a rich history. It was the concerted effort of charter historians who opened up the search for pre-colonial sources, both written and oral, that challenged the entrenched view of many historical professionals, such as the Professor of Modern History at Oxford University, Hugh Trevor-Roper, who as late as 1963 claimed that pre-colonial Black Africa had no history. ${ }^{1}$

Before the late 1940s there was no written history of Africa in the Western academic tradition that considered the African perspective of events. Neither was there a general history of the whole African continent published before the 1950s. Several prominent English-trained academics and a few notable American scholars joined a growing number of Africanists to create the new discipline of African History, which grew rapidly in the late 1940 s and 1950 s. $^{2}$ By the late 1950 s, British academics stood out as the leaders in African historical research. The year 1960 was pivotal in the recognition of African History, as it was the year that the English academics John Fage and Roland Oliver launched the Journal of African History in association with Cambridge University Press. The Journal of African History was the first history journal to embrace a multidisciplinary approach to the African historical past, and included articles by archaeologists, anthropologists and linguists, as well as by historians. In the same year, 1960, the United Nations (UN) made a formal acknowledgement that all colonised people had the right to independence. The UN's Declaration on Granting Independence to Colonial Countries and Peoples stated that 'all peoples' have the right to self-determination. ${ }^{3}$ Significantly, the creation of the 
Journal of African History occurred as the UN recognised African rights to self determination.

Several emeritus scholars who helped develop African History have reflected upon key moments during the past fifty years of the discipline's growth. Some, like John Fage, have listed important moments like the establishment of British African Universities in 1948. Roland Oliver and Jan Vansina believed that the 1953 and 1957 conferences on African History and Archaeology, held at the School of Oriental and African Studies (SOAS), marked the recognition of African History as an academic subject. Philip Curtin also recognised the publication of the Journal of African History in 1960 as a landmark in the discipline's creation. Yet, few acknowledged the background to these events, preferring to write of their 'golden years' when the field began to thrive. Their comments led me to search for various government reports on education, where indeed I found a wealth of information. I discovered that source material for pre-colonial Africa was mentioned by academics, but little elaboration was made by them on how these impacted on the development of the discipline. Memoirs, government reports and reflective essays shaped the direction of my study towards the role of infrastructure in establishing African History.

In addition to memoirs, there are also references to academic infrastructure within many historiographical essays on African History, but they are considerably limited in scope. That said, they do offer pointers towards the role that infrastructure played in the formation of the discipline. For example, John McCracken wrote a reflective essay on the development of the discipline in 1993, acknowledging that the expansion of British Higher Education related to the subsequent emergence of African History at British Universities. ${ }^{4}$ McCracken provided an overview of the state of African Studies in British universities since the 1950s. In order to examine the infrastructure behind the discipline of African History, I have broadened the search beyond the historiography of African History to the historiography on educational development in Africa, Britain and the United States.

As with the overview approach taken by McCracken, studies on the development of African History generally focus on key texts, historians and contextual events, and tend to follow a chronological format rather than a thematic approach. A major part of these 'standard' historiographical essays is a review of the literature of African History. It is also common for historiographical essays to focus on the development of the 
discipline relative to specific geographical areas. For example, the Oxford History of the British Empire (hereafter $O H B E$ ) dedicates volume five to historiography and includes several chapters that relate to the development of African History in the United Kingdom. ${ }^{5}$ These chapters focus on how the discipline favoured certain areas within British Africa and reflected the regionalism preferred by historians. OHBE, vol. $V$ offers a good overview of British academic attention towards the African past and contains examples of standard historiographical essays on African History. However, there is no detailed evidence provided on how these histories and historians impacted upon the development of the discipline, a theme that I intend to explore in this thesis.

A standard approach to writing about the development of African History found in $O H B E$, vol. $V$ is A. D. Roberts' chapter 'The British Empire in Tropical Africa: A Review of the Literature to the 1960s'.6 Roberts' chapter contains contextual information and descriptions of the major developments in writing on Africa. The work is authoritative, detailing events and theoretical shifts as a teleological narrative. Roberts' own background, which incidentally was given little attention in $O H B E$, vol. $V$, is relevant to the infrastructure and growth of the discipline. Roberts trained in African History under one of the most influential historians of the discipline, Jan Vansina, at the University of Wisconsin-Madison. ${ }^{7}$ Subsequently, Roberts was an integral figure in teaching at important institutions, and he published significant works that reflected the training he received. After completing his Ph.D. in 1966 he became one of the first American historians to work at the new University College of Dar es Salaam in Tanzania. He then moved to the School of Oriental and African Studies at the University of London, becoming Professor of the History of Africa and now Emeritus Professor. Roberts was also the editor of the Cambridge History of Africa Volume Seven and the former editor of the Journal of African History between 1974 and $1990 .{ }^{8}$ My thesis will explore the background of key African historians, such as Roberts, to shed light on the contribution they made to the establishment of African History.

A model for this Master of Arts thesis on the infrastructure of African History is Lewis Hanke's reflective essay on the development of Latin-American History in the United States. Hanke's 'The Development of Latin-American Studies in the United States, 1939-1945' looked beyond the role of historians to the infrastructure supporting the academic discipline. ${ }^{9}$ His essay, written in 1947 during the initial development of the discipline, devotes a considerable amount of space describing how the academic 
infrastructure supporting the discipline was created. According to Hanke, the development of Latin American Studies in the United States during the Second World War resulted from the combined efforts of state and private organisations, such as the Rockefeller Foundation. ${ }^{10}$ Government and private foundations drove the direction of academic study into different fields of enquiry, resulting in an interdisciplinary approach, the growth of Inter-American conferences and the establishment of University courses in Latin American Studies. Furthermore, Hanke noted that the development of the discipline was linked to the expansion of research and the creation of new publications, including bibliographies of existing sources and the expansion of libraries in the field. His approach is a major departure from the approach of the standard historiographical essay available for African History.

Like Hanke, my thesis will detail the development of an academic discipline-in this case, African History. My thesis will be both thematic and chronological, and will show how over a broad time period the links between infrastructure, sources and historians drove the development of the discipline. I am concerned with the crucial moments that impacted upon African History's position in British and American universities. While I focus on the growth of African History in English and American institutions, written by historians trained within English and American university systems, it must be acknowledged that Africans have recorded their own past in numerous ways. Also, many non-English speaking peoples-such as the French, Portuguese and Spanish - have had considerable relationships with Africa over time. This thesis limits itself to the English-speaking historical tradition where the modern discipline of African History developed. This in turn has contributed to my decision to focus generally, but not exclusively, on the presentation of history for the areas of West Africa that relate directly to the English colonial past.

Chapter One examines the infrastructure of British West African colonies that impacted on the development of the discipline. The aim of this chapter is to illustrate that the development of academic African History was linked to the continued English presence in Africa, from the foundation of the English Colony at Sierra Leone in 1787, to the beginning of university courses at Fourah Bay College, Sierra Leone in 1876, and then to the decision by the Elliot and Asquith committees to develop British African Universities in $1948 .^{11}$ I examine the development from missionary education to government education, focusing on several crucial reports between 1911 and 1945. Importantly, this chapter will illustrate that governmental contributions to educational 
development led to the creation of British universities in Africa that directly impacted on the creation of African History as a discipline during the late 1940s. This has been acknowledged in passing, but never considered as pivotal to the creation of African History.

Chapter Two will discuss how, alongside the growth of British-African education in Africa, there was continuous expansion of education in African Studies in the United Kingdom driven by British strategic interests. I will demonstrate how government funding intersected with pedagogical initiatives to place Africa, by the 1960s, in the mainstream of British higher education. I spotlight three important government reports between 1947 and 1963 concerning education. In addition, I focus on the pioneering historians who during this period played a key role in the development of African History.

Chapter Three examines the development of African History as a discipline in the United States. Like the growth of the discipline in the United Kingdom, African History as an academic subject in the United States advanced through a perceived national need, which resulted in an injection of funds to energise the study of Africa. African History, as a separate discipline in the United States, owes its existence to the infrastructural support given to the creation of academic departments, and perhaps, more importantly, to the historians who staffed them. While the contribution of key historians runs as a theme throughout all four chapters of this thesis, this chapter focuses on the role of Philip Curtin and Jan Vansina in developing African History at the University of Wisconsin. Key historians, like Curtin and Vansina, taught African history throughout the 1950s and 1960s, laying the foundation of the discipline. Among the many contributions of the first generation of trained African historians was an emphasis on a critical evaluation of extant source material.

The final chapter of this thesis investigates the contribution of sources to the discipline. One of the most important aspects of African History's development was the recognition that Africa had a pre-colonial past. I look into how the availability of sources and their limitations impacted on the presentation of pre-colonial African History, ca.1450-1800. This chapter examines closely how source material often drove the way historians studied pre-colonial African history by investigating how the discipline relies on a few written European sources and African oral testimonies. I also spotlight two important port regions of pre-colonial West Africa, Sierra Leone and 
New Calabar (Nigeria), and explore how historians have marshalled written and oral sources to present the pre-1800 history of these regions.

This thesis, then, examines the development of African History as an academic discipline in British and American universities in the 1940s, 1950s and 1960s. I show how this growth emerged from the creation of the British colony in Sierra Leone in 1787 to the expansion of missionary activity there. As colonial territories expanded in the nineteenth and early twentieth centuries, British government officials, aware of Africa's increased strategic importance, took over the educational endeavours begun by missionary teachers. After the Second World War, governmental and private funding promoted the development of African Studies in British and U.S. universities. Historians participated in the expansion and development of the discipline by researching source material, writing histories and building programmes to train students. These factors combined to form a solid foundational infrastructure for African History, the theme of this thesis. 


\section{Notes to Introduction}

${ }^{1}$ This statement was made by Hugh Trevor-Roper during a series of lectures at the University of Sussex transmitted by BBC Television. The lectures also appeared in The Listener in 1963. The same comments were reiterated by Hugh Trevor-Roper in his book: The Rise of Christian Europe, London: Thames and Hudson, 1965. See also Hugh Trevor-Roper, 'The Past and Present: History and Sociology', Past and Present, Vol. 42, No. 1, 1969, pp. 3-17.

${ }^{2}$ Throughout this thesis I have adopted the following convention, 'African History' refers to the academic discipline, whereas 'African history' refers to the history of Africa and its peoples.

${ }^{3}$ United Nations, Official Documents System of the United Nations, 'The Declaration on Granting Independence to Colonial Countries and Peoples', http://daccessdds.un.org/doc/RESOLUTION/GEN/NR0/152/88/IMG/NR015288.pdf?OpenEle ment, last accessed 10 April 2007.

${ }^{4}$ John McCracken, 'African History in British Universities: Past, Present and Future', African Affairs, Vol. 92, No. 367, April, 1993, pp. 239-253.

${ }^{5}$ Wm. Roger Louis (ed.), The Oxford History of the British Empire, vol. V, Historiography, Oxford U.K.: Oxford University Press, 1999. (Hereafter OHBE vol. V). The chapters are as follows: John E. Flint, Chapter 29, 'Britain and the Scramble for Africa', pp. 450-462; A.D. Roberts, Chapter 30, 'The British Empire in Tropical Africa: A Review of the Literature to the 1960s', pp. 463-485; Toyin Falola, Chapter 31, 'West Africa', pp. 486-499; Charles Ambler, Chapter 32, 'East Africa: Metropolitan Action and Local Initiative', pp. 500-512; William H. Worger, Chapter 33, 'Southern and Central Africa', pp. 513-540.

${ }^{6}$ A.D. Roberts, Chapter 30, 'The British Empire in Tropical Africa: A Review of the Literature to the 1960s', in Wm. Roger Louis (ed.), The Oxford History of the British Empire, vol. V, Historiography, Oxford U.K.: Oxford University Press, 1999, pp. 463-485.

${ }^{7}$ All subsequent references to University of Wisconsin refer to the Madison campus.

${ }^{8}$ A.D. Roberts 'The Sub-Imperialism of the Baganda', The Journal of African History, Vol. 3, No. 3, 1962, pp. 435-450.

${ }^{9}$ Lewis Hanke, 'The Development of Latin-American Studies in the United States, 19391945', The Americas, Vol. 4, No. 1, July, 1947, pp. 32-64. Both Latin America and Africa have a similar contextual past which involved large independent civilisations, subsequent conquest and were subject to slavery and colonisation and eventual post-colonial independence. The growth and direction of Latin American Studies was driven by the developments of U.S. scholars while African History was largely driven by British scholars. Prior to the Second World War Latin American Studies was limited in approach by U.S. historians who held a condescending approach to the regions history in much the same way that British historians viewed Africa as void of history. After the Second World War this steadily changed into a more unbiased historical view.

${ }^{10}$ Hanke, 'The Development of Latin-American Studies in the United States, 1939-1945', p. 32. Hanke notes that the interest of scholars in the area since 1900 had a role to play in the expansion of Latin American Studies.

${ }^{11}$ Senegambia was the first English colony in Africa established in 1765, but it was abandoned in 1783. Sierra Leone became the first permanent English colony to be established in Africa. 


\section{CHAPTER ONE}

\section{THE DEVELOPMENT OF AFRICAN HISTORY, 1787-1948: THE EVOLUTION OF BRITISH AFRICAN UNIVERSITIES}

Reflecting on the development of African History in 1971, John Fage, then Professor of African History at the Centre of West African Studies, University of Birmingham, stated:

The modern period in the writing of West African history begins...with the development of the history departments in the new universities established in West Africa itself from 1948 onwards, and with the more or less contemporaneous development of the serious study of African history in universities elsewhere, first perhaps in Britain and the USA. ${ }^{1}$

Fage acknowledges that the creation of the discipline of African History is inexorably linked to the establishment of British universities in Africa. Fage is considered by many in the field to be one of the founding fathers of the discipline and one of the most influential historians of Africa in the United Kingdom. ${ }^{2}$ Like Fage, Roland Oliver is considered by Africanists to be one of the founders of the discipline. ${ }^{3}$ Oliver had the distinction of holding the first lectureship in African History in Britain at the School of Oriental and African Studies, London in 1948, the same year Fage names as the beginning of the modern period of West African History. Both the development of African universities in British colonies and the appointment of the first lecturer in African history in a British University are seminal moments in the development of African History as an academic discipline in the Western world.

John Fage, by linking the start of African History as a discipline with the establishment of universities in Africa in 1948, indicated a connection between the growth of formal Western education in Africa, the creation of British universities in Africa and the growth of the field of African History. This chapter builds upon Fage's statement by showing that the birth of the modern discipline of African History had its origins in the development of an educational infrastructure in Africa that emerged as a result of British strategic interests in trade and security. This growth occurred through the changing political relationship between England and its African colonies between 1787 and 1948.

First I will illustrate how the initial educational developments made in Sierra Leone became a blueprint for British education across all of British West Africa until 
the late 1940s. I will then outline the development of the key concepts of 'trusteeship' and 'adaptation' that were embraced in educational policy, and examine the major British colonial government reports on education which occurred after the First World War and again after the Second World War that resulted in the creation of British African Universities in 1948.

\section{Sierra Leone: The beginnings of an educational tradition}

The development of education in British Africa started in Sierra Leone with the Portuguese in the fifteenth century. The English continued the Portuguese tradition of Christian education in Sierra Leone and at Fourah Bay established a continued presence on the peninsula leading to its eventual colonisation in the eighteenth century. Missionary activity was an integral component of this continuity and the actions of English evangelicals laid a foundation of Christian education in the colony of Sierra Leone that set the pattern of formal education for all of British Africa. Sierra Leone was the first place in British West Africa to have a missionary training centre, an English secondary school and an English university affiliated college. Africans educated at Sierra Leone went on to become leaders throughout Africa. In Sierra Leone, an infrastructure had been set in place for the integration of missionary education with formal government education and the provision for African higher education in the humanities.

Sierra Leone was one of the most visited regions of West Africa by Europeans after the fifteenth century. Colonisation by the English in 1787 guaranteed Sierra Leone as a crucial base for all future British expansion in West Africa. ${ }^{4}$ The Portuguese were the first Europeans to establish trading settlements along the Upper Guinea Coast from Senegal to Sierra Leone during the fifteenth and sixteenth centuries. The Portuguese were replaced by the Spanish during the second half of the seventeenth century. The English, while dominating trade in the area after 1650 and establishing a succession of forts, remained sporadic visitors to the area until the last decades of the eighteenth century. ${ }^{5}$ The Portuguese and Spanish established Catholic missions, imparting their faith and traditions to the surrounding peoples, beginning a slow process of religious conversion. ${ }^{6}$ According to Paul Hair, the influence of Spanish Catholicism 'lasted almost until the beginnings of Protestant missions in the 1790s'. ${ }^{7}$ Hair argues that despite the lack of constant English settlement and the lack of English missionary 
attempts before 1787, the English did frequent Sierra Leone often enough to lay foundations for later colonial settlement. ${ }^{8}$

Between 1787 and 1793 British evangelicals and abolitionists established a colony in Sierra Leone for freed slaves, both from England with its recent abolitionist laws, and ex-servicemen from the War of Independence in America. The colony faltered, and in 1792 was reinforced by a second wave of colonists, black Loyalists from Nova Scotia, under the control of the Sierra Leone Company. ${ }^{9}$ The colonists continued the tradition of religious education started by the Portuguese missionaries in the fifteenth century. Bible instruction and sermons were made available to the exslaves from 1792 and was viewed an essential part of the civilising mission of the colony. In contrast to the local Africans, the bulk of the settlers who were of African descent spoke a form of English, had English names and attended Christian services. ${ }^{10}$ The founders of the colony hoped that the settlement would serve as a base to expand Christianity into Africa and develop trade. Integral to both of these ideals was education. The benefit of European education for trade purposes had long been acknowledged by the local rulers who had been sending their children to Europe since the middle of the eighteenth century. ${ }^{11}$ Sierra Leone offered the local rulers an alternative to sending their children to Europe for education. There was such a large demand for education in the colony that it outstripped the availability of teachers. ${ }^{12}$

A more focused and deliberate attempt was made between 1795 and 1804 to expand missionary activity in Sierra Leone. This expansion was related to the foundation of the Missionary Society at London in 1795 whose aim was to expand Christian missions to foreign peoples. ${ }^{13}$ In 1797 the London Missionary Society sent several missionaries to Sierra Leone in an effort to extend Christianity beyond the confines of the colony to the indigenous Africans. ${ }^{14}$ The success of the Missionary Society's preachers was limited amongst the Sula and the Fula peoples, and by 1799 they had stopped sending missionaries. The activities of the Missionary Society in Sierra Leone were replaced by the Church Missionary Society (CMS), founded in 1799. The CMS was associated with the Clapham sect, the original founders of the colony, with many of its members prominent in both organisations. ${ }^{15}$ The first CMS missionaries went to Sierra Leone in 1804, beginning a long and influential association with Sierra Leone.

The abolition of the slave trade by the British Parliament in 1807 had dramatic effects for educational growth in the colony of Sierra Leone. From 1807 Sierra Leone 
became a drop-off point for slaves rescued by the British navy from slave trading ships. These slaves, known as 'recaptives', bolstered the population of the colony. ${ }^{16}$ In 1808 the Crown took control of Sierra Leone from the Sierra Leone Company. With the government reluctant to become deeply involved in the affairs of the colony the CMS expanded its role in Freetown and became the de facto British government in Sierra Leone. ${ }^{17}$ Throughout the nineteenth century the CMS continued its emphasis on the expansion of education for Africans in both the English language and the Protestant faith. ${ }^{18}$ Alongside the establishment of facilities for the education of Africans, Freetown became an important place where European missionaries could learn about Africans and study their languages before heading inland to spread the word of God. ${ }^{19}$ In 1827 The CMS recognised that they needed to expand facilities to teach the growing number of 'recaptives', and founded Fourah Bay College to train missionary teachers. ${ }^{20}$ Fourah Bay College was the first English African College specifically designed to train missionary teachers and marks an important step in the process of European educational development in Africa. ${ }^{21}$ Missionary education was so important in Sierra Leone that by 1841, thirty-three years after Sierra Leone had become a British Crown colony, no established governmental pattern of education existed in Sierra Leone: out of the forty two schools only fourteen were government schools, the rest being Church Missionary Society or Wesleyan. ${ }^{22}$

The CMS continued to dominate the development of educational facilities in Sierra Leone throughout the latter part of the nineteenth century. In 1845 the CMS extended educational facilities in Sierra Leone with the opening of the first West African secondary grammar school, and in 1876 Fourah Bay College, in association with the University of Durham, became Africa's first institution offering English university courses. ${ }^{23}$ Both these institutions were missionary operated and funded, and in the case of Fourah Bay College the decision to offer university level education in arts subjects was the CMS's reaction to pressure from educated Africans. ${ }^{24}$ The CMS introduced arts subjects at university level to Fourah Bay College to allay the fear that the government might create an African University run along purely secular educational lines, like that suggested by Edward Wilmot Blyden. ${ }^{25}$ Blyden was one of the first educated Africans to advocate the teaching of African subjects at Fourah Bay College. Blyden had gained the support of the British administrator of Sierra Leone, J. Pope Hennessy, and advocated the teaching of 'African languages, songs and oral tradition, and a form of Christianity adapted to the African people'. ${ }^{26}$ His pressure did not create 
the secular educational institution that he had hoped for; instead Fourah Bay College remained the extension of existing missionary education with the inclusion of secular subjects. There was, however, some concession as Fourah Bay College created programmes for the study of African languages in West Africa. These courses were not designed to expand the education of Africans but to instruct missionaries so they could spread Christianity through vernacular languages.

The development of missionary education in Sierra Leone, particularly that of higher education at Fourah Bay College, influenced all later British educational policy in West Africa. ${ }^{27}$ Eminent African historian Emmanuel Ayankanmi Ayandele notes that the high quality of graduates produced at the Church Missionary Society's grammar school and the affiliation of Fourah Bay with the University of Durham were crucial moments in the development of African intellectual progress in Western education. ${ }^{28}$ It was at the educational institutions of Sierra Leone that prominent African intellectuals and leaders received their education. ${ }^{29}$ Some of the most important graduates were Samuel Ajayi Crowther, James Beale Horton, Nathaniel S. King, Sir Samuel Lewis, Christian F. Cole, James Johnson, Isaac Oluwole, Henry Johnson, Henry Rawlinson Carr, Joseph Ephraim Casely-Hayford, Herbert Samuel Heelas Macaulay, and Kenneth Onwuka Dike. ${ }^{30}$ Dike is considered today by Africanists as one of the founding fathers of African History, receiving an education at Fourah Bay College in the 1940s. ${ }^{31}$ In Sierra Leone the foundation of Western education in Africa was created, and an infrastructure developed that would spread education throughout British Africa, ultimately leading to the creation of African History as an academic subject.

\section{The developments of a governmental policy for British Africa, 1880- 1918}

In 1884, eight years after university courses began at Fourah Bay College in Sierra Leone, members of fifteen European states met at the Berlin Conference and decided to partition the African continent. The 1880s mark the point at which Africa began to be gradually placed under the control of colonial powers, culminating in the dominance of Africa by Europeans by the end of the First World War in $1918 .{ }^{32}$ During the 'Scramble for Africa', the British extended their territories and became a dominant power in the African continent. In 1882 the British occupied Egypt, followed by Sudan, Nigeria, Kenya and Uganda in the 1890 s. $^{33}$ By the end of the Great War the British had gained 
over one million square kilometres of the African continent, extending its pre-1880s land a thousand fold. After the First World War German territories in Africa were divided between Belgium, Great Britain and France. The British obtained one third of Togoland and part of the Cameroons bordering Nigeria. The most sizeable British acquisition was the German territory of Tanganyika in East Africa. ${ }^{34}$

As the English expanded their African territories, a gradual transformation from missionary education to formal education took place. Until the end of the First World War in 1918, university education in British Africa remained the domain of the missionary-controlled Fourah Bay College. Along with the increase in British colonial control over areas of Africa there came an increased feeling of responsibility for the education of Africans in the Colonial Office. The Colonial government and the existing missionary organisations combined to address responsibility for education not only in Sierra Leone but across the larger and more populated areas of its governance, such as Nigeria and the Gold Coast.

The development of Colonial policy towards education in African territories embraced two related concepts in the beginning of the twentieth century. The first concept was that of 'trusteeship', which was conceived in the Imperial mindset as the moral responsibility of the more 'civilised' colonial power to administer governance to African peoples. 'Trusteeship' implied that the advancement of African people was to be guided by the Colonial Office through colonial educational policies that wed African demands for improvement and English educational standards and curriculum. ${ }^{35}$ The second key concept developed was 'adaptation', which was the altering of the British educational curriculum to the African situation. Thus, 'trusteeship' found its outward expression in the policy of 'adaptation', which formed the basis of the educational strategy adopted by the Colonial Office and missionary organisations in Africa.

A clear example of the concepts of 'trusteeship' and 'adaptation' can be seen in the first decades of the twentieth century when British administrators turned their attention to educating the citizens of the expanding British Empire. In 1907 the Ministry of Education in London held a series of groundbreaking meetings on the development of education in the British Empire. The outcome of these meetings was the decision to hold, in 1911, the first Imperial Conference on education in London. The Report of the Imperial Education Conference, 1911 emphasised the need to simplify the English language in order to spread literacy amongst colonial peoples. Along with an emphasis on literacy the report contained a paper on the education of Africans in Sierra Leone, 
'Notes on the Psychology of the Negro Child and on the Adaption of Primitive Customs, Manners and Traditions in a System of Education', prepared by the Director of Education in Sierra Leone, Mr R. F. Honter, and submitted to the conference by the Governor of Sierra Leone. ${ }^{36}$

Sierra Leone, with its long tradition of established educational facilities for Africans, offered Honter and the members of the Imperial Conference an excellent example of the state of education in an African colony. Honter described the nature of the predominantly missionary education delivered to the descendents of recaptured slaves, or Creoles as they were known, who formed the bulk of the population in the colony centred on Freetown. Importantly, Honter also looked beyond Freetown to the larger area of Sierra Leone known as the Protectorate, inhabited by indigenous Africans. Honter noted that there was a discrepancy between the education delivered by missionary societies in Freetown and in the Protectorate. In Freetown the Creoles had received a European based education for over a hundred years, while the Africans of the Protectorate were the recipients of what can be best described as conversional education, which emphasised practical agricultural training. ${ }^{37}$ Honter believed that European education in Sierra Leone had proceeded along two divergent paths, which had separated rather than integrated the indigenous African inhabitants from the Creoles. The Creoles and the Africans who lived in Freetown had formed an educated elite, many having received an academic education at institutions like Fourah Bay College. This group had become disjointed from the rest of the mainly indigenous populace of the Protectorate who saw little value in British education, preferring their traditional educational methods. ${ }^{38}$

For Honter the solution to the discrepancy in education was to adapt the education in both territories. Honter recommended that education for the indigenous Africans of the Protectorate should be a modified form of British education that stressed the development of practical skills rather than the higher literary knowledge taught at Freetown. In Honter's view:

education must begin with something of commercial value. Some time in the future, education might be valued for its own sake, but the first step has to be in the direction of returns in money or kind. It appears to me that this is the only way in which education can be successfully introduced. ${ }^{39}$

Honter's report reflects an early concept of both 'adaptation' and 'trusteeship', and it also makes clear that by 1911 the pressure exerted for higher education in African 
territories during the 1870 s had suffered a dramatic setback. Honter suggested that the Colony and Protectorate should share the same system of education tailored to suit the masses. The emphasis of the policy of 'adaptation' on the development of practical skills, such as English literacy and agriculture, clearly indicate that British administrators were concerned with the growth of an education system that would benefit the commercial machinery of Empire. Higher education like that offered at Fourah Bay College, while acknowledged as important in the long term development of the colonies, was not seen as a pressing need by the British colonial administration. 'Trusteeship' in essence entailed a measure of steady control over the pace of educational change.

Between the 1880s and the end of the First World War, the need to administer British African colonies led officials to acknowledge that educational expansion in Africa was inevitable. In order to control this expansion the concepts of 'trusteeship' and 'adaptation' emerged, which would ultimately form the genesis of later governmental policy for African education. These two concepts would evolve in the imperial mindset to recognise the importance of African higher education and play a fundamental role in the decision to create universities in Africa and the expansion of African studies in the United Kingdom.

\section{The establishment of formal education in British African colonies, 1918-1925}

In the aftermath of the First World War and the 1918 Peace Settlement the advancement of British educational policy for Africa increased dramatically. As a result of the War, British African possessions increased and so did the contribution of the African colonies to the war effort. The commitment of African resources and personnel to the war effort strengthened the commitment in Britain to develop education in the colonies. ${ }^{40}$ While the British government acknowledged the need for an overall educational policy for colonial territories in Africa, the direction that education would develop in Africa was again guided by the underlying concepts of 'trusteeship' and 'adaptation' and the practical involvement of missionary groups, in particular the effort of Dr. Joseph Houldsworth Oldham, the Secretary of the Conference of Protestant Missionary Societies in Great Britain. ${ }^{41}$ 
Oldham was a trusted advisor of the British government on religious matters during the 1920s and 1930s. He had a lifelong interest in the educational development of Africans and perceived '[t]he need for broader missionary perspectives and closer cooperation between missions and state if African interests were to be served in the modern world'. ${ }^{42}$ Through Oldham, the promotion of education in Africa was greatly expanded by the British government. In the early 1920s Oldham organised two missionary enquiries into African education known as the Phelps-Stokes Commissions. The Phelps-Stokes Commissions recommended that the educational policy adopted in the British Territory of South Africa be introduced to Tropical Africa. South Africa had introduced the reforms suggested by E. B. Sargent, the Educational Adviser to the British High Commissioner to South Africa. Sargent's reforms were a classic example of 'adaptation', as outlined previously in Honter's report of 1911, and stressed that Africans should primarily be taught literacy and industrial skills rather than higher education. ${ }^{43}$ Oldham supported the findings of the Phelps-Stokes Commissions, and with the backing of already established African missionary organisations he was able to influence the direction of government educational policy. In 1923 Oldham organised the Derby Day Meeting between members of the government, industry and missionary organisations. The outcome of this meeting was the creation of the Colonial Advisory Committee (CAC), whose role was to frame educational policy in Africa. Oldham maintained a strong influence over the three groups involved in the CAC; the Government, industry and missionary organisations, until his resignation in 1934. He was able to ensure that missionary organisations retained the largest influence over educational developments in Africa. ${ }^{44}$

Missionary pressure exerted through the unofficial Phelps-Stokes Commissions' findings and the personal influence of Oldham resulted in the drafting, with Sir Frederick Lugard, of the 1925 publication of the Colonial Advisory Committee, Education Policy in British Tropical Africa (Cmd. 2374). ${ }^{45}$ The policy of 'adaptation' found official expression in the 1925 report:

Education should be adapted to the mentality, aptitudes, occupations and traditions of the various peoples, conserving as far as possible all sound and healthy elements in the fabric of their social life; adapting them where necessary to changed circumstances and progressive ideas, as an agent of natural growth and evolution...Education thus defined will narrow the hiatus between the educated class and the rest of the community whether chiefs or peasantry. As a part of the general policy for the advancement of the people every department 
of government concerned with their welfare or vocational teachingincluding especially departments of Health, Public Works, Railways, Agriculture - must co-operate closely in the educational policy. ${ }^{46}$

The report, issued as a government white paper, acknowledged that British educational policy had hitherto been largely devoid of an overall plan and that missionary education had been the bulwark of education for Africans. ${ }^{47}$ Significantly, the British government did not take over missionary education but moved to control the administration of education and cooperate with existing mission schools to enact the policy of 'adaptation'. ${ }^{48}$ Provision for higher education was also made in the report but its emphasis was downplayed as the priority was explicitly for mass education. ${ }^{49}$ Colonial administrators saw education as a way to increase the contribution of the colonial territories towards the development of Empire and to raise the indigenous population towards civilisation. ${ }^{50}$ The 1925 Report, while reflecting the recommendations of the earlier 1911 Report, was a more important step towards combining African education with government strategic needs.

According to Professor Thomas Walter Wallbank, the British colonial office policy on education during the 1920s contained three fundamental assumptions. The first was the concept of 'trusteeship': the 'responsibility to utilize all those agencies, of which education is perhaps chief, which contribute towards raising the African in the scale of civilization. This is an altruistic conception of the obligation which a colonial power owes to her native wards'. ${ }^{51}$ Wallbank's second point 'is that education has a vital connection with industry, trade, and markets... Thus the whole economic structure of a colony advances with the progress of education'. ${ }^{52}$ The third and most important point was that while the British were committed to increasing African participation in governmental policy, education was used to 'retard the creation of a vociferous, yet numerically insignificant, intelligentsia divorced from the great mass of their own inarticulate people, yet demanding impossible political concessions'. ${ }^{3}$ Wallbank, significantly, highlights the important relationships at work in the colonial education policy, which married education with commercial interest in an attempt to safeguard British Imperial interests. The colonial educational policy in Africa during the 1920s saw the development of an infrastructure that instituted the policy of 'adaptation' into African territories and had the effect of restricting higher education in Africa to a trickle, emphasising mass education and practical skills, particularly that of agriculture over higher education. ${ }^{54}$ 
The intersection of Imperial responsibility and commercial interest can be seen in the dependence of educational expansion in British tropical African colonies during the 1920 s on economic growth. During the late nineteenth century the British government had declined to support the funding of higher education 'from the conviction that limitations of finance and educational progress made it inexpedient' ${ }^{55}$ However, as economic growth developed in colonial territories during the 1920s so did schemes for the expansion of education. With the combined support of missionary organisations and sufficient funding from local administration, educational facilities could be expanded, laying the basis for later higher educational development. For example, the increase in revenue led directly to the colonial commitment to expand education on the Gold Coast by creating The Prince of Wales College, known as Achimota College (opened in 1927), in Accra. As Wallbank wrote:

It was th[e] development in cacao culture which increased the government's revenues and made possible the financing of an ambitious educational program of which Achimota was a part. Cacao, and cacao alone, explains why educational expenditure could be increased from $£ 54,000$ in 1919 to $£ 289,000$ in 1930 . $^{56}$

The Gold Coast was the largest producer of cacao in West Africa and at one stage produced over seventy five percent of the world's cacao. ${ }^{57}$

Achimota College is an example of the institutionalisation of the 1925 white paper and Honter's observations on British colonial policy towards African education in the 1920s. Achimota College was developed after the First World War by the governor of the Gold Coast, Sir Frederick Gordon Guggisberg, who was influenced by the findings of the Phelps-Stokes Commissions. ${ }^{58}$ Guggisberg constructed a Secondary School, which he envisioned would eventually offer technical courses and teacher training, which would be a stepping stone towards an African university. ${ }^{59}$ Construction of Achimota College began in 1924, and while a few courses were taught from this time, the College did not officially open until 1927, and began offering higher education courses in 1929. The creation of Achimota College reflected the comments of the 1925 white paper, which stated that 'rapid development of our African Dependencies on the material and economic side demands and warrants a corresponding advance in the expenditure on education'. ${ }^{60}$ The concept of 'adaptation' stressed in the 1925 white paper also found solid implementation at Achimota College as courses contained a mandatory component of agricultural training: 
It must not be thought that Achimota's curriculum is "academic." As the main economic basis for the colony is agriculture, specifically cacao, this subject is given special attention. It is a compulsory subject for all secondary students, both girls and boys, and also for those enrolled in the Teacher Training Department. ${ }^{61}$

Furthermore, the religious and moral instruction of African students was given high priority at Achimota College, also reflecting the values of the 1925 white paper. ${ }^{62}$ Along with the increased economic revenue, the Colonial government had become aware of a growing responsibility towards its African wards.

Between 1918 and the 1925 white paper, missionaries and colonial administrators developed the provision for educational facilities in Africa. While the 1925 white paper limited the advancement of higher education in Africa along the lines of that available for English students in the United Kingdom, it did reflect the growing commitment shown by Colonial administrators towards advancement of African education. This commitment was encouraged by recognition of the strategic need to advance colonised peoples in economically developing territories. During the 1920s the British colonial administration and missionary societies had become became partners in developing a formal policy for African education, which would deliver Christian education to important British territories, under the auspices of 'trusteeship' and 'adaptation'. The creation of Achimota College in 1924 reflects the advancement of such a policy for educational expansion.

\section{The educational transition to African universities, 1929-1948}

During the build up to the Second World War the British colonial government increased its attention on the development of education in British African territories. By the end of the Second World War the provision for higher education in these territories had been officially recognised as essential for Africans and for the strategic interests of Britain. Between 1929 and 1948, provision for the expansion of educational facilities was made possible through the recommendation of three reports on colonial development: the 1929/30 First interim report of the Colonial Development Advisory Committee (Cmd. 3540); the 1939/40 Statement of policy on Colonial development and welfare (Cmd. 6175); and the 1945/46 Despatch dated 12th November, 1945, from the Secretary of State for the Colonies to Colonial Government (Cmd. 6713). These three reports provide an example of the strategic value that Britain placed upon its foreign colonies 
during a period of growing German rivalry in Africa. The 1929/30 First interim report of the Colonial Development Advisory Committee (Cmd. 3540) made the initial step towards funding improvements in colonial infrastructure. The report recommended that a sum of $£ 1$ million a year be made available for developmental purposes in British colonies. However, this amount was largely insufficient for the demands of all of the British overseas territories. ${ }^{63}$ The next major report on colonial development, Statement of policy on Colonial development and welfare (Cmd. 6175), occurred after the outbreak of the Second World War in 1939. The report made provision for the expansion of the 1929 Colonial development report increasing the allowance for development from $£ 1$ million to $£ 5$ million each year for a maximum of ten years. While the writers of the report acknowledged that the rate of progress in implementing its recommendations would necessarily slow down as a result of the war, the fact that any increase at all during a time of war was suggested outlines the strategic importance that the British Government placed on the Colonies. ${ }^{64}$

The largest commitment to funding development in African territories came only months after the end of the Second World War, in the form of the 1945/46 Despatch dated 12th November, 1945, from the Secretary of State for the Colonies to Colonial Government (Cmd. 6713). ${ }^{65}$ This report made provision for a dramatic increase in funding from the 1929 development and welfare report. In 1929 the provision for development was $£ 1$ million per year. In 1939/40 this increased to $£ 5$ million per year for a period of ten years, but after the 1945/46 report it increased to $£ 17,500,000$ per year and the period was extended for another five years. The provision for an increase in funding for Colonial territories at a time when the British economy was weakened from six years of war, indicates the strategic importance that Britain had placed in her overseas territories. The 1945/46 report states:

This increase in the total sum to be provided and the lengthening of the period of such assistance by a further five years mark an important turning point in the development of Colonial productive resources and the improvement of human well-being. It comes at a time when a gradual easing of war-time shortages of materials, equipment and skilled technical scientific personal may be hoped for. There are great possibilities in the years that lie ahead for raising the standards of health, education and social welfare, and general well-being of Colonial peoples if these expanded services are based upon improved economic efficiency and increased production. The primary requisite still is an improvement of the economic position in the Colonial Dependencies, the utilisation of their natural resources 
to the greatest extent possible and the widening of opportunity for human enterprise and endeavour. ${ }^{66}$

The increase in funding for colonial development shown in the Colonial Office reports of the 1930s and 1940s signalled the transition from missionary dominated education towards a greater governmental role in African education. The reports on Colonial development had a direct impact on both the pace and the importance associated with the development of African territories. It was, however, a series of educational reports that were conducted throughout this period that put in place the manner in which colonial education would be developed and where higher educational facilities would be established.

Alongside the reports recommending the development of overseas colonies in the 1930s and 1940s, fear of German expansion also forced Britain to re-examine its framework for higher education in African territories. ${ }^{67}$ There were six reports into education conducted between 1933 and 1945: the Currie Report of 1933; the De La Warr Report of 1937; The Channon Memorandum, 1940; the Channon Report 1943; the Elliot Report 1945; and the Asquith Report $1945 .{ }^{68}$ Both the 1933 Currie and 1940-43 Channon Reports recommended an immediate expansion of higher education in African territories. However, the Colonial Office largely ignored these detailed reports, for two reasons. ${ }^{69}$ The first stumbling block was the reluctance of the British Colonial Governors to commit to the development of higher educational facilities in their territories. ${ }^{70}$ The second obstacle was the Second World War, which diverted attention away from the development of education facilities towards the more pressing concerns of the War effort, inadvertently supporting the lack of enthusiasm shown by the Colonial Governors towards educational development. With the end of hostilities in 1945, both the local governors and the Colonial government acknowledged that British Africa was on a path towards self-rule, and only through partnership in education could British and African interests be mutually served. ${ }^{71}$

The two most important reports for the expansion of higher education in British African territories were the Elliot and the Asquith reports, which were both published at the end of the War in $1945 .^{72}$ These two reports marked the fullest recognition of the policy of 'trusteeship' expressed in the 1940, Colonial Development and Welfare Report. ${ }^{73}$ The Elliot and Asquith Reports represented a dramatic change from the 1920s educational policy of 'adaptation' favoured by the government and then dominant missionary educational institutions, which stressed practical subjects and a curb on 
higher education. By 1945 the concept of 'trusteeship' embraced the crucial acknowledgement that it was the not only the moral duty of the colonial government to improve the education, health and economy of African societies, but also their duty to prepare African peoples for eventual self-governance. ${ }^{74}$ As the Asquith Report states:

His Majesty's Government has entered upon a programme of social and economic development for the colonies which is not merely the outcome of a desire to fulfil our moral obligations as trustees of the welfare of Colonial peoples, but is also designed to lead to the exercise of self government by them. In the stage preparatory to self government universities have an important part to play; indeed they may be said to be indispensable. ${ }^{75}$

With the emphasis placed on the essential development of higher education by the Elliot and Asquith Reports the concept of 'adaptation', which stressed a curriculum of practical subjects, was joined by the provision for the creation of universities offering higher education. ${ }^{76}$

The Elliot and Asquith Reports formed the basis for the British government's expansion of higher education in British Africa after 1945. Both Reports were presented in June 1945, and the Elliot Report shared two members with the Asquith Report. ${ }^{77}$ The Elliot Report looked specifically at the development of higher education in West Africa and recommended the extension of existing facilities at Sierra Leone, Ghana and Nigeria. ${ }^{78}$ The Asquith Report examined the development of higher education across all British colonies and recommended the additional establishment of university colleges in Sudan and Uganda. ${ }^{79}$ These five colonies represented the most important British interests in Africa after the Second World War. ${ }^{80}$

The Asquith Report was accepted as the overall plan for the development of universities in British colonial territories, and when combined with the Elliot Report's specific plans for the development of higher education in West Africa provided the blueprint for the development of African universities. The Asquith Report recommended the creation of an Inter-University Council to facilitate the establishment and administration of the future University Colleges. The Inter-University Council met for the first time on 8 March 1946, and after a series of meetings the members of the committee in November 1947 approved the creation of the university colleges in Africa and the implementation of the recommendations of the Asquith Report. ${ }^{81}$ The Asquith Report had become the outline for the exportation of British universities to overseas colonies. By 1948 five University colleges were established in British Africa. Four were affiliated with the University of London: the University College Gold Coast (Ghana); 
University College Ibadan (Nigeria); University of Khartoum (Sudan); and the University of Makerere (Uganda). The fifth university college, Fourah Bay College (Sierra Leone), remained affiliated with the University of Durham as it had been since $1876^{82}$

The development of African History as a discipline owes its existence to the implementation of the Asquith Report in 1945. With the Colonial Office approval to create university colleges in Africa and expand higher education, the Report put into place the creation of an infrastructure that would lead directly to the formation of African History as an academic tradition. Two important recommendations contained within the Asquith Report contributed directly to the development of African History. The first recommendation was the insistence on the encouragement of British academics to staff the new institutions. ${ }^{83}$ The second was that staff, in accordance with the nature of the British academic tradition, must be able to undertake original research. ${ }^{84}$ The Asquith Report had put in place an infrastructure that supported the research and adaptation of courses such as history to be tailored to the local area. ${ }^{85}$ This insistence on original research by academic staff opened the way for recruited British scholars to play a fundamental role in local research, ultimately opening up the field of African History. The change was not immediate, and not until the 1960s would African History become accepted as an academic discipline in its own right. ${ }^{86}$ However, the new 'Asquith' colleges as they were known, staffed by British academics, led ultimately to the creation of the discipline of African History. ${ }^{87}$ African History began developing away from Imperial History as the African past became acknowledged and academically legitimised.

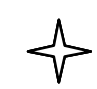

The formal creation of four British sponsored African universities in 1948 to supplement Fourah Bay College in Sierra Leone led to the establishment of an educational infrastructure in Africa. From 1787 to 1948 a shift occurred from sporadic informal education to institutionalised formal university education in Africa. Missionary control gradually gave way to an increased involvement by the British government as Africa gained strategic importance through the First and Second World Wars. The Colonial Office expanded upon the earlier work of missionary societies, and produced a series of educational reports that over the years matured into the policy of 'trusteeship' and 'adaptation' expressed in the Elliot and Asquith Reports of 1945. Underlying the 
creation of these educational reports was the British desire to retain strategic and commercial influence after African colonies gained independence. These reports led directly to the expansion of higher education in Africa and an ideology that stressed the adaptation of curriculum that included the research of peoples and places previously considered void of history. By 1948 there was an educational infrastructure within British African territories that set the path for the development of the discipline of African History that exists today. It was from the new university colleges of Africa, located in the most important areas of British Africa, that African History was born, and it was in the hands of the predominantly English trained academics that African History was researched and written. In Chapter Two I examine how the need for higher education in Africa generated an awareness of the need for scholars to be trained formally in African History. 


\section{Notes to Chapter One}

${ }^{1}$ J.D. Fage, 'Continuity and Change in the Writing of West African History', African Affairs, Vol. 70, No. 280, July, 1971, pp. 236-251, see p. 244. Fage is referring to the University College of Ibadan, Nigeria and the University College of the Gold Coast, Legon, (Ghana), both started in 1948. In reality there were five universities with links to British institutions: Fourah Bay College (Sierra Leone) affiliated since 1876 with the University of Durham, and four new universities affiliated with the University of London, the University of the College Gold Coast (Ghana) 1948, University College Ibadan (Nigeria) 1948, the University of Khartoum (Sudan) 1946, and the University of Makerere (Uganda) 1949.

2 [Douglas Rimmer] D.R., 'John Donnelly Fage', The Journal of African History, Vol. 27, No. 2, Special Issue in Honour of J.D. Fage, 1986, pp. 193-201.

${ }^{3}$ [Michael Crowder] M.C., 'Roland Oliver', The Journal of African History, Vol. 29, No. 1, Special Issue in Honour of Roland Oliver, 1988, pp. 1-4.

${ }^{4}$ The early Portuguese explorers considered the peninsula and immediate surrounding port areas of the estuary as the principal region of Sierra Leone. By the first British attempt at colonisation in 1787 the region of Sierra Leone was seen by the colonists as being made up of two distinct regions. The first of these was the colony founded at Freetown on the peninsula. The second region comprised the area immediate surrounding the colony and extending to the border of Guinea and Liberia - the Sierra Leone hinterland. After the Sierra Leone Colony's transformation into a crown colony in 1808, steady British expansion in the region resulted in the British claiming the hinterland as a protectorate in 1896. Thus, by the end of the nineteenth century the modern borders of what we know today as Sierra Leone had been largely established.

${ }^{5}$ P.E.H. Hair, 'Christian Influences in Sierra Leone before 1787', Journal of Religion in Africa, Vol. 27, Fasc. 1, West African Christian History: A Tribute to A.F. Walls, the Journal's Founding Editor, Thirty Years on, February, 1997, pp. 3-14, see p. 8; Hair, 'Franciscan Missionaries and the 1752 'Donation of Sierra Leone', Journal of Religion in Africa, Vol. 30, Fasc. 4, November, 2000, pp. 408-432; Christopher Fyfe, A History of Sierra Leone, London: Oxford University Press, 1962, pp. 4-11.

${ }^{6}$ Peter Mark, 'The Evolution of 'Portuguese' Identity: Luso-Africans on the Upper Guinea Coast from the Sixteenth to the Early Nineteenth Century', The Journal of African History, Vol. 40, No. 2, 1999, pp. 173-191, see p.173; Hair, 'Christian Influences in Sierra Leone before 1787', pp. 6-7. Portuguese Jesuits actively practised in Sierra Leone from 1605 to 1617. The most famous of these was Father Baltesar Barreira and Father Manuel Alvares whose writings for the early Sierra Leone region are amongst the most important for the period.

${ }^{7}$ Hair, 'Franciscan Missionaries and the 1752 'Donation of Sierra Leone', p. 408.

${ }^{8}$ Hair, 'Christian Influences in Sierra Leone before 1787', pp. 9-10.

${ }^{9}$ Fyfe, History of Sierra Leone, pp. 31-37.

${ }^{10}$ Arthur T. Porter, 'Religious Affiliation in Freetown, Sierra Leone', Africa: Journal of the International African Institute, Vol. 23, No. 1, January, 1953, pp. 3-14. see pp. 4-5.

${ }^{11}$ Fyfe, History of Sierra Leone, pp. 11, 30, 54-55; Hair, 'Christian Influences in Sierra Leone before 1787', p. 5.

${ }^{12}$ Fyfe, History of Sierra Leone, pp. 55, 69.

${ }^{13}$ Ibid, p. 75, Fyfe dates the founding of the Missionary Society to 1795 and its renaming to the London Missionary Society in 1818. So does, MUNDAS, the online guide to Missionary Societies in the United Kingdom, School of Oriental and African Studies, University of London, 'London Missionary Society', http://www.mundus.ac.uk/cats/4/251.htm, accessed 27 August 2007. David G. Scanlon (ed.), Traditions of African Education, New York: Bureau of Publications Teachers College, Columbia University, 1964, p. 2. Scanlon dates the founding of the London Missionary Society to 1792.

${ }^{14}$ Scanlon (ed.), Traditions of African Education, p. 3; Fyfe, History of Sierra Leone, p. 5.

${ }^{15}$ Church Missionary Society Britain, 'A Brief History of CMS', http://www.cmsuk.org/Whoweare/History/tabid/181/Default.aspx, last accessed, 12 September 2007. 
${ }^{16}$ Fyfe, History of Sierra Leone, pp. 136-140. This increase occurred from 1807 onwards. Fyfe notes for example that in 1816 alone, 2545 recaptives landed in Sierra Leone. The arrival numbers fluctuated each year but the number of immigrants was enough to affect the population of Sierra Leone greatly.

${ }^{17}$ Porter, 'Religious Affiliation in Freetown, Sierra Leone', pp. 8-9, Porter argues that the state and the CMS worked together and the CMS was seen as synonymous with British rule gaining prestige and power in the area. The British government was happy with this state of affairs as can be seen by the fact that the British Government did not have a department to administer overseas colonies until the creation of the Colonial Office in 1825 and the appointment of a permanent undersecretary. Fyfe, History of Sierra Leone, p. 105. Fyfe notes that after the transfer of the colony to the Crown, the founders, influential members of the Clapham sect, continued to operate a civilising mission in Sierra Leone through the Church Missionary Society and a private trading company.

${ }^{18}$ Fyfe, History of Sierra Leone, p. 127.

${ }^{19}$ Hildegard Binder Johnson, 'The Location of Christian Missions in Africa', Geographical Review, Vol. 57, No. 2, April, 1967, pp. 168-202, p. 174.

${ }^{20}$ Fyfe, History of Sierra Leone, p. 172.

${ }^{21}$ Kingsley Banya, 'Illiteracy, Colonial Legacy and Education: The Case of Modern Sierra Leone', Comparative Education, Vol. 29, No. 2, 1993, pp. 159-170, see pp. 165-166.

${ }^{22}$ Eric Ashby, Universities: British, Indian, African: A Study in the Ecology of Higher Education, London: Weidenfeld and Nicolson, 1966, p. 149. Ashby notes that a majority of teachers in the governmental schools were trained by church organisations and taught a predominantly religious curriculum.

${ }^{23}$ Ashby, Universities: British, Indian, African, pp. 151, 166; Eric Ashby, African Universities and Western Tradition: The Godkin Lectures at Harvard University 1964, Cambridge, Massachusetts: Harvard University Press, 1964, pp. 12-15.

${ }^{24}$ Ashby, Universities: British, Indian, African, pp. 169-179. Ashby ackowledges the role of James Africanus Beale Horton, Edward Wilmot Blyden and J.E. Casely Hayford. Horton a Sierra Leonean Creole, was educated at the CMS Grammar School and then at Fourah Bay College, Kings College, London and Edinburgh University, qualifying as a doctor and serving as a Surgeon Major in the British Army. Blyden was born in St. Thomas, Virgin Islands and emigrated to Liberia where he was educated at Alexander High School, Monrovia. While not educated in Sierra Leone, Blyden was active in Sierra Leone and according to Ashby, p. 165, without 'Blyden's intervention, it is unlikely that the Church Missionary Society would have undertaken to pioneer the cause of higher education in West Africa so soon'. Casely Hayford was born in Ghana, educated at Fourah Bay College and qualified as a barrister at the University of Cambridge. See also Ashby, African Universities and Western Tradition, pp. 13-14.

According to Ashby, Hayford pressed for the founding of a British West African University at the 'First Conference of Africans of British West Africa' held at Accra in 1920. Hayford believed that such a university should aim to give African students a sense of African nationality. Gerald T. Rimmington, 'The Development of Universities in Africa', Comparative Education, Vol. 1, No. 2, March, 1965, pp. 105-112, see p. 105. Like Ashby, Rimmington acknowledges the role of African intellectuals in pressuring for higher education.

${ }^{25}$ Ashby, Universities: British, Indian, African, pp. 164-166.

${ }^{26}$ Ashby, African Universities and Western Tradition, p. 13; Ashby, Universities: British, Indian, African, pp. 153, 164-166.

${ }^{27}$ Ashby, Universities: British, Indian, African, p. 149.

${ }^{28}$ E.A. Ayandele, African Historical Studies, London: Frank Cass, 1979, pp. 82-85.

${ }^{29}$ Ashby, Universities: British, Indian, African, pp. 154-157. In addition to Fourah Bay there were other influential educational institutions in Sierra Leone, for example, the school for the sons and nominees of chiefs at Bo was created in 1905. According to Ashby, p. 157, the school 'planned to introduce the future chiefs and leaders to the learning of the West without divorcing them from their own cultural background: to train them, in the words of the official report, "not 
in an alien system of thought and education' but in such a way as would equip them the most usefully for the part they were destined to play'.

${ }^{30}$ Ayandele, African Historical Studies, pp. 82-85, 139; Ashby, Universities: British, Indian, African, pp. 148-189. See the following works for some of the expansive literature written about important people who passed through Fourah Bay; E.A. Ayandele, Holy Johnson: Pioneer of African Nationalism, 1836-1917, New York: Humanities Press, 1970; Davidson Nicol, (ed.), Africanus Horton: The Dawn of Nationalism in Modern Africa: Extracts from the Political, Educational and Scientific Writings of J.A.B. Horton M.D., 1835-1883, London: Longman, 1969; Christopher Fyfe, Africanus Horton, 1835-1883, West African Scientist and Patriot, New York: Oxford University Press, 1972; Edith Holden, Blyden of Liberia: An Account of the Life and Labors of Edward Wilmot Blyden, LL.D., As Recorded in Letters and in Print, New York: Vantage Press, 1966; R. Lynch, Edward Wilmot Blyden: Pan-Negro Patriot, London: Oxford University Press, 1967; R. Lynch, (ed.), Black Spokesman: Selected Published Writings of Edward Wilmot Blyden, London: Frank Cass, 1971. See also The Sierra Leone Web, 'Heroes', http://www.sierra-leone.org/heroes3.html, last accessed 25 October 2007 and Sierra Leone Grammar School Alumni in the United Kingdom, C. Magbaily Fyle, 'The Grammar School and Education in Sierra Leone, 1845-1942',

http://www.regentonians.org/templates/slgs.asp?articleid=2\&zoneid=1, last accessed 10 October 2007.

${ }^{31}$ Ebere Nwaubani, 'Kenneth Onwuka Dike, "Trade and Politics", and the restoration of the African in History', History in Africa, Vol. 27, 2000, pp. 229-248. Dike completed his B.A. at Fourah Bay College, Sierra Leone, and his M.A. at Aberdeen University. Dike's 'Trade and Politics in the Niger Delta, 1830-1879', was his Ph.D. thesis, with the qualification awarded in 1950 from the University of London. His supervisors were the prominent Imperial historians Vincent Harlow and Gerald S. Graham.

${ }^{32}$ Excluding Ethiopia and Liberia.

${ }^{33}$ Fletcher School, Tufts University, Multilaterals Project, 'Covenant of the League of Nations, Article 22, signed on 28 June 1919', http://fletcher.tufts.edu/multi/www/league-covenant.html, last accessed 10 November 2007. The Covenant contains the terms agreed for the system by which German colonies would become mandated territories of the Allies.

${ }^{34}$ German South-West Africa (now Namibia) was mandated to the Union of South Africa in 1922.

${ }^{35} \mathrm{~T}$. Walter Wallbank, 'Educational Renaissance in British Tropical Africa', The Journal of Negro Education, Vol. 3, No. 1, January, 1934, pp. 105-122, see p. 106. Trusteeship found its ultimate realisation when African colonies gained independence in the late 1950s and 1960s.

${ }^{36}$ R.F. Honter, Notes on the Psychology of the Negro Child and on the Adaption of Primitive Customs, Manners and Traditions in a System of Education' in Cmd. 5666 Report of the

Imperial Education Conference, London: H.M.S.O., 1911, pp. 228-337.

${ }^{37}$ Ibid, pp. 230-231.

${ }^{38}$ Ibid, pp. 231-232.

${ }^{39}$ Ibid, p. 236.

${ }^{40}$ Wallbank, 'Educational Renaissance in British Tropical Africa', pp. 105-122. Henry

D'Souza, 'External Influences on the Development of Educational Policy in British Tropical

Africa from 1923 to 1939', African Studies Review, Vol. 18, No. 2, September, 1975, pp. 35-43. D'Souza, like Wallbank, explained that the British policy on education in Africa south of the Sahara, was known as a policy of 'adaptation' and that the policy of 'adaptation' in education was linked to the economic concerns of the West.

${ }^{41}$ After an impressive education in India, England and Germany, Oldham was appointed fulltime secretary for the Edinburgh World Missionary Conference of 1910. His administrative success led to his appointment as secretary of the 'Edinburgh continuation committee' and in 1912 he became the editor of the International Review of Missions, and remained so until 1927. Oldham focused on international missionary cooperation and between 1921 and 1938 was the secretary of the International Missionary Council. From 1931 to 1938 he was the Administrative Director of the International Institute of African Languages and Cultures and between 1925 and 
1936 he was an active member of the Advisory Committee on Education in the Colonies. During 1927 and 1928 he was a member of the East African Commission on Closer Union, editor of the Christian Newsletter between 1939 and 1945 and Senior Officer of the Christian Frontier Council from 1942 to 1947. For a comprehensive biography of Oldham see the following two works, Keith Clements, Faith on the Frontier: A Life of J.H. Oldham, Edinburgh: T. \& T. Clark, 1999; Kathleen Bliss and Andrew Porter, Oxford Dictionary of National Biography, 'Oldham, Joseph Houldsworth (1874-1969)', Oxford University Press, 2004; online edition, May 2007, http://www.oxforddnb.com/view/article/35301, last accessed 16 November 2008.

${ }^{42}$ Kathleen Bliss and Andrew Porter, Oxford Dictionary of National Biography, 'Oldham, Joseph Houldsworth (1874-1969)', Oxford University Press, 2004; online edition, May 2007, http://www.oxforddnb.com/view/article/35301, last accessed 16 November 2008.

${ }^{43}$ D'Souza, 'External Influences on the Development of Educational Policy in British Tropical Africa from 1923 to 1939', pp. 37-38. Thomas Jesse Jones (Chairman), African Education Commission 1920/21, Phelps-Stokes Fund, Education in Africa: A Study of West, South, and Equatorial Africa by the African Education Commission under the Auspices of the PhelpsStokes Fund and Foreign Mission Societies of North America and Europe, New York: PhelpsStokes Fund, 1922, pp. 16-35.

${ }^{44}$ D'Souza, 'External Influences on the Development of Educational Policy in British Tropical Africa from 1923 to 1939', p. 42. D'Souza states, 'Oldham arranged the Derby Day Meeting which established the Colonial Advisory Committee (CAC), a de facto executive body under the Colonial Secretary. This body, which controlled education in tropical Africa, including the Dependencies from 1929, was represented by the three estates of the realm: industry, administration and the Church. Until 1934 when Oldham resigned from the CAC, the Church had a dominant say in the nomination of CAC members. Oldham kept a steady correspondence with the Directors of Education in the colonies, was responsible for some of their transfers, and acted as liaison between bodies interested in African education and the Colonial Office. Oldham's intense and often successful lobbying within the precincts of the Colonial Office prompted one M.P. to say, "The Colonial Office in these days was in fact a Ministry of Education". See also Clements, Faith on the Frontier: A Life of J.H. Oldham, p. 223. ${ }^{45}$ Sir F.D. Lugard, The Dual Mandate in British Tropical Africa, Edinburgh: William Blackwood and Sons, 1922. Lugard outlined the concepts of 'indirect rule' and 'educational adaptation' which when combined amounted to 'trusteeship'. He worked alongside missionaries to develop colonial policy. For a biography of Lugard see Thomas P. Ofcansky, 'A BioBibliography of F.D. Lugard', History in Africa, Vol. 9, 1982, pp. 209-219. See J.F.V. Phillips (Chairman), The Committee of Inquiry into African Education Report, Government Printer, Zomba, Nyasaland, 1962, pp. 23-24. The Phelps Stokes Commission is acknowledged in this official educational report as being responsible for pressuring the government into making an educational policy for colonial territories and for the development of the Board of Education. Nyasaland is present day Malawi.

${ }^{46}$ Cmd. 2374, Education Policy in British Tropical Africa, London: H.M.S.O., 1925, p. 4.

${ }^{47}$ Ibid, p. 3; Wallbank, 'Educational Renaissance in British Tropical Africa', pp. 105-122. Wallbank, pp. 108-109, gives an idea of the scope of the extent of missionary education in Africa. White papers are issued by the British government and lay out the intention of the government to pass legislation, and as such reflect government policy.

${ }^{48}$ Cmd. 2374, Education Policy in British Tropical Africa, London: H.M.S.O., 1925; Bob W. White, 'Talk about School: Education and the Colonial Project in French and British Africa, (1860-1960)', Comparative Education, Vol. 32, No. 1, March, 1996, pp. 9-25, see p. 13.

${ }^{49}$ Cmd. 2374, Education Policy in British Tropical Africa, London, 1925, p. 4. The report did recommend the inclusion of African examples in text books for Geography and History and the development of textbooks in vernacular languages.

${ }^{50}$ Wallbank, 'Educational Renaissance in British Tropical Africa', p. 106. Wallbank puts this into perspective, 'Great Britain's share in this responsibility is particularly striking in Africa where the Colonial Office presides over the destinies of some forty million natives. It is 
primarily through education that the tremendous potentialities of Britain's African dependencies can be developed and their people raised to higher standards of life'. Wallbank taught at the University of Southern California and won the American Historical Association, Watumull Prize, in 1951 for his book India in the New Era, Chicago: Scott Foresman and Co., 1951. His main areas of research were Africa and India.

${ }^{51}$ Ibid, pp. 106-107.

${ }^{52}$ Ibid.

${ }^{53}$ Ibid, Wallbank has taken his information from the educational report Cmd. 3234, Report of the Commission on Closer Union of the Dependencies in Eastern and Central Africa, London: H.M.S.O., 1929.

${ }^{54}$ Ibid, p. 107; D'Souza, 'External Influences on the Development of Educational Policy in British Tropical Africa from 1923 to 1939', pp. 38-39; Charles Peter Emudong, 'The Gold Coast Nationalist Reaction to the Controversy over Higher Education in Anglophone West Africa and its Impact on Decision Making in the Colonial Office, 1945-47', The Journal of Negro Education, Vol. 66, No. 2, Spring, 1997, pp. 137-146, see p. 139; Ashby, Universities: British, Indian, African, pp. 190-193.

${ }_{55}^{55}$ Ashby, Universities: British, Indian, African, p. 181.

${ }^{56} \mathrm{~T}$. Walter Wallbank, 'Achimota College and Educational Objectives in Africa', The Journal of Negro Education, Vol. 4, No. 2, April, 1935, pp. 230-245, see p. 234.

${ }^{57}$ Jackson Davis, 'Education in British West Africa', The Journal of Negro Education, Vol. 15, No. 3, The Problem of Education in Dependent Territories, Summer, 1946, pp. 358-369, see p. 365 .

${ }^{58}$ Achimota School, http://www.ac2010.org/about_achimota.html, last accessed 3 December 2007; Achimota School, 'Sir Frederick Gordon Guggisberg',

http://www.ac2010.org/guggisberg_biography.html, last accessed 3 December.

${ }^{59}$ Ashby, Universities: British, Indian, African, p. 188.

${ }^{60}$ Cmd. 2374, Education Policy in British Tropical Africa, London: H.M.S.O., 1925, p. 5.

${ }^{61}$ Ibid, p. 240.

${ }^{62}$ Ibid, p. 244. See Wallbank, 'Achimota College and Educational Objectives in Africa', pp. 243-245, for a discussion on the Christian principles of the school.

${ }^{63} \mathrm{Cmd}$. 3540, First Interim Report of the Colonial Development Advisory Committee covering the period $1^{\text {st }}$ August 1929-2 $8^{\text {th }}$ February 1930, London: H.M.S.O., 1930, p.7. This report was passed as a bill in 1929.

${ }^{64}$ Cmd. 6175, Statement of Policy on Colonial Development and Welfare, London: H.M.S.O., 1940, pp. 4-6.

${ }^{65}$ Cmd. 6713, Colonial Development and Welfare: Despatch dated 12th November, 1945, from the Secretary of State for the Colonies to Colonial Governments, London: H.M.S.O., 1945. The report was passed as a bill in 1945.

${ }^{66}$ Ibid, p. 2.

${ }^{67}$ D'Souza, 'External Influences on the Development of Educational Policy in British Tropical Africa from 1923 to 1939', p.40; I.C.M. Maxwell, Universities in Partnership: The InterUniversity Council and the Growth of Higher Education in Developing Countries 1946-70, Edinburgh: Scottish Academic Press Ltd, 1980, p. 9.

${ }^{68}$ D'Souza, 'External Influences on the Development of Educational Policy in British Tropical Africa from 1923 to 1939', p. 40.

${ }^{69}$ Ashby, African Universities and Western Tradition, p. 24. According to Ashby the Currie Report written in 1933, published in 1935 as Colonial Office, Col. No. 103, Advisory Committee on Education in the Colonies. Memorandum on the Education of African Communities, London: H.M.S.O., 1935, 'called for an immediate and publicly announced programme of university development; otherwise the report said, enlightened African opinion would be alienated and British prestige in Africa would be lost'. The Currie Report and the Channon Report are reproduced in full in Ashby, Universities: British, Indian, African, pp. 476-524, and are clear evidence of the shift in the curriculum of 'adaptation' towards higher education. 
${ }^{70}$ Ashby, Universities: British, Indian, African, p. 190. See also Emudong, 'The Gold Coast Nationalist Reaction to the Controversy over Higher Education in Anglophone West Africa and its Impact on Decision Making in the Colonial Office, 1945-47', p. 139.

${ }^{71}$ John Flint, 'Planned Decolonization and Its Failure in British Africa', African Affairs, Vol. 82, No. 328, July, 1983, pp. 389-411.

${ }^{72}$ Asquith Report, Cmd. 6647, Report of the Commission on Higher Education in the Colonies, London: H.M.S.O., 1945; Elliot Report, Cmd. 6655, Report of the Commission on Higher Education in West Africa, London: H.M.S.O., 1945. The Elliot Report was split into a majority report and a minority report. The recommendations of the majority report were accepted.

${ }^{73}$ Cmd. 6175, Statement of Policy on Colonial Development and Welfare, London: H.M.S.O., 1940, p. 4. This report was passed a s a bill in 1940.

${ }^{74}$ J.D. Hargreaves, The Idea of a Colonial University, African Affairs, Vol. 72, No. 286, January, 1973, pp. 26-36, see pp. 28-29. For a broader discussion on the development of the policy of 'trusteeship' see John J. Sbrega, 'Determination versus Drift: The Anglo-American Debate over the Trusteeship Issue, 1941-1945', The Pacific Historical Review, Vol. 55, No. 2, May, 1986, pp. 256-280. Sbrega mentions the role of Anthony Eden, the British Foreign Secretary, in the discussions of 'trusteeship' held between the United States of America and Britain during the War. Interestingly, Eden was later directly involved in the Scarbrough Report and the decision to start study centres and university departments for the study of Africa in the United Kingdom. See also Huntington Gilchrist, 'Trusteeship and the Colonial System', Proceedings of the Academy of Political Science, Vol. 22, No. 2, Developing a Working International Order: Political, Economic and Social, January, 1947, pp. 95-109. Gilchrist was a member of the USA delegation to the United Nations and wrote a summary of the events and intentions of 'trusteeship'. Also see, H. Duncan Hall, 'The British Commonwealth and Trusteeship', International Affairs, Vol. 22, No. 2, March, 1946, pp. 199-213, for a discussion of trusteeship and the proposed role of the British Commonwealth in Africa.

${ }^{75} \mathrm{Cmd}$. 6647, Report of the Commission on Higher Education in the Colonies, London: H.M.S.O., 1945, p. 10.

${ }^{76}$ Ashby, African Universities and Western Tradition, pp. 17, 19.

${ }^{77} \mathrm{Cmd}$. 6655, Report of the Commission on Higher Education in West Africa, London:

H.M.S.O., 1945, preface, p. vi.

${ }^{78}$ Ibid, pp. 126-127.

${ }^{79}$ Cmd. 6647, Report of the Commission on Higher Education in the Colonies, London: H.M.S.O., 1945, pp. 9, 13, 104.

${ }^{80}$ Stephen Addae, The Gold Coast and Achimota in the Second World War, Ghana: Sedco Publishing, 2001. Addae notes on the dust-jacket that 'Achimota College was the headquarters of the West Africa command, from where the Royal West African frontier force was organised. Secondly, British resident ministers, sent to the Gold Coast by Churchill's government to coordinate the war effort in West Africa, had their offices at Achimota. Achimota was also a key educational institution in West Africa, and led to the establishment of the University College of the Gold Coast at Achimota in 1948'.

${ }^{81} \mathrm{Cmd}$. 7331, Report of the Inter-University Council for Higher Education in the Colonies, 1946/47, London: H.M.S.O., 1948, pp. 1-12.

${ }^{82}$ Ibid, p. 6; Ashby, Universities: British, Indian, African, pp. 214-215; Ashby, African Universities and Western Tradition, p. 19.

${ }^{83} \mathrm{Cmd}$. 6647, Report of the Commission on Higher Education in the Colonies, London: H.M.S.O., 1945, Chapter Five, 'The Staffing of Universities', pp. 19- 26.

${ }^{84}$ Ibid, Chapter Six, 'The Place of Research', pp. 26-29.

${ }^{85}$ Ibid, p. 104. The Elliot Report made the same recommendations, Cmd. 6655, Report of the Commission on Higher Education in West Africa, Chapter IV, 'The Future of Higher Education in West Africa', pp. 51-59, see p. 55. Ashby, Universities: British, Indian, African, p. 221. Ashby points out that the Asquith and Elliot Report's emphasised the need for local research. ${ }^{86}$ Ashby, African Universities and Western Tradition, p. 19.

${ }^{87}$ Hargreaves, 'The Idea of a Colonial University', pp. 33, 35-36. 


\section{CHAPTER TWO}

\section{THE ESTABLISHMENT OF AN ACADEMIC INFRASTRUCTURE FOR AFRICAN HISTORY IN THE UNITED KINGDOM}

Chapter Two examines academic African History in England from 1787 to 1963, using British government reports as evidence of change and growth. During these two centuries the growth of higher education in Africa and the expansion of interest in African History in Britain became inexorably linked. Importantly, this chapter will explain how educational and political advances put in place an infrastructure that contributed to the creation of the modern discipline of African History. In doing so I illustrate that the requirement for study of Africa and its people was the result of a strategic need, which resulted in the emergence of teaching positions in institutions in British African colonies and British universities in England. I first look at the growth of academic African History in the United Kingdom after the establishment of the British colony at Sierra Leone in West Africa in 1787 until the government's 1947 publication known as the Scarbrough Report. ${ }^{1}$ I then spotlight how the Scarbrough Report contributed to the discipline's development. The first ten years after the Scarbrough Report was a key period of academic infrastructural development. Two major reports emerged, the Hayter Report and the Robbins Report, which finally established African History within academic institutions in the United Kingdom. ${ }^{2}$

\section{The transition to academic African History in Britain: From 1787 to the recommendations of the Scarbrough Report in 1947}

In Great Britain formal university courses on Africa and its people were limited before the late 1940s. Nevertheless, educated Britons learned some information about Africa and its people from the published works of travellers and explorers as well as newspapers and exhibitions. The First World War and the Second World War also increased public attention on Africa and increased the numbers of English people who travelled to the continent. Along with an increased awareness of Africa followed an increased need for cultural and geographical information about the region and its peoples. Early travellers to the region also needed to develop basic African language skills, and during the periods of war this became a necessity. 
The forebears of African History departments in the United Kingdom were private societies formed by intellectuals and wealthy businessmen in the eighteenth century. One such society was the Association for Promoting the Discovery of the Interior Parts of Africa, more commonly known as the African Association, which was founded in 1788 by a group of wealthy individuals, including Sir Joseph Banks. The primary function of societies like the African Association was to fund exploration and the gathering of knowledge on foreign territories. ${ }^{3}$ The African Association funded the pioneering explorations of Mungo Park along the Niger, Frederick Hornemann's trip to Fezzan, John Lewis Burckhardt's journey through Egypt and Nubia, and the artist Henry Salt's exploration of Ethiopia and Egypt. The information gained by these adventurers was published and exhibited, and represented some of the earliest popular accounts of Africa and its peoples. The African Association merged with the Geographic Society in 1831 and the society gained its Royal Charter in $1859 .{ }^{4}$ The Royal Geographic Society's main function was to scientifically record and map the globe, and thus its information served a strategic importance to the commercial and military expansion of Empire.

The most important private organisation to promote the study of Africa from a cultural perspective was the African Society, founded in 1901 in posthumous recognition of the pioneering work on West Africa produced by Mary Kingsley. ${ }^{5}$ The African Society gained a Royal Charter in 1935, becoming the Royal African Society. It is interesting to note that this society was financed from donations by two educated Africans, Mr. R. B. Blaize and Dr. E. W. Blyden. ${ }^{6}$ This was the same Edward Blyden who had argued vigorously for the creation of a West African University in the late nineteenth century. Blyden became the first vice-president of the African Society. As such, the society had since its inception been concerned with the promotion of knowledge and the education of both British and African peoples.

The strategic importance of education both for Africans and Europeans was acknowledged in a speech made by Frederic Shelford at the Society's inaugural meeting in 1901. Shelford, introduced to the meeting as 'the largest employer of labour in West Africa', pointed out the importance of Africa in terms of the size of population, the number of natural resources available for home industry, and the value of marketing goods back to the Africans themselves. ${ }^{7}$ Furthermore, Shelford made an important connection: 
Why is it that for hundreds of years West Africa has been regarded as the darkest spot of Darkest Africa? Why is it that for scores of years our merchants have lived on the edge of the sea and have bought from the natives only such palm oil, kernels, rubber and other products as they chose and have sold to the natives such European goods as the natives have happened to hear of and to require? Why have the natives not produced more? Why have they not bought more from us? Why in fact has not the trade between this country and those Colonies been greater? Why has our knowledge of these Colonies been chiefly derived from the wars we have waged against them? Why did we have to fight the Ashantis again and again till 1896 ? Why did we have to punish the Benins in 1897? Why did the Mendis rise in 1898? Why did we have to fight the Ashantis again in 1900 ? Is not the answer to all these questions to be summed up in one word-"Ignorance". 8

From this, Shelford argued that the only way to alleviate ignorance and improve the opportunities for development was to educate the West Africans as well as the English. ${ }^{9}$ Shelford had realised in 1901, forty-seven years before the first chair of African History was appointed in the United Kingdom, that along with the development of education for Africans there was also a strategic need for the British to be educated about Africa. Shelford's comments share a remarkable similarity to the later comments made in government reports promoting the study of Africa in Britain after 1945.

The African Society promoted the dissemination of knowledge about African peoples in Britain through the establishment of its pioneering publication the Journal of the African Association. The importance of this journal was summed up in the 1951 fiftieth jubilee edition that noted that since its creation in 1901 until the 1920s 'there was no other Society or Journal devoted mainly to the investigation of African life and customs'. ${ }^{10}$ Along with the publication of the Journal of the African Association, the contribution of the African Society to the development of formal African studies took practical shape in the contribution of one of its most promising staff members, Alice Werner, to the newly formed School of Oriental Studies (SOS) at the University of London in 1916. Alice Werner became a lecturer in Swahili at the School and was joined by her sister Mary. ${ }^{11}$ The two Werner sisters were responsible for teaching African languages until their retirement in the 1930s.

The creation of the SOS tacitly acknowledged the importance of the study of Oriental and African languages to the administration of the Colonial Empire. Some provision for the study of Oriental languages and literature had been available in Britain at Oxford and Cambridge since the seventeenth century, but there was no single centre 
that focused specifically on languages or taught introductory language courses for diplomats and government officials in London. The University of London decided to meet the need for such an institution, and in 1905 the university council recommended that a school be set up within the University of London to expressly teach Oriental languages. ${ }^{12}$ In 1908, a committee of inquiry approved the recommendation for the formation of a separate constituent college within the University of London. After a decision was made to situate the new school at Finsbury Circus in London, the process went on hold until 1912 when Parliament passed an act to create the SOS. In 1914 funding was approved, but with the outbreak of the First World War the creation of the institution was delayed. Sir Philip Hartog, the main proponent for the creation of the school, promoted the usefulness of the institution in the War effort, and in 1916 SOS received its Royal Charter, finally opening in February $1917 .{ }^{13}$ The school's location in London related directly to its role in training diplomats and government officials for foreign posts, central to the post-1918 expansion of British territory in Africa. ${ }^{14}$

During the 1930s SOS focused on the practical teaching of foreign languages. Officials recognised that training also should be given in Literature, History, Religion and Customs of foreign peoples, but those fields remained limited at the school during this decade. ${ }^{15}$ In 1932 the School was reorganised into eight departments. There were six for the study of languages and cultures, one for Oriental history and Law, and one for phonetics and linguistics. The regional departments were: Ancient India and Iran; Modern India and Ceylon; South East Asia and the Islands; the Far East; the Near East; and Africa. ${ }^{16}$ The regions and languages studied at SOS in the 1930s reflected areas of British government and business interest. In recognition of the growing importance of British territories in Africa and with the help of a Rockefeller Foundation Grant, SOS gradually built up an African studies department between 1932 and 1937 with a staff of six specialists in African languages. ${ }^{17}$ In 1938 it changed its title to the School of Oriental and African Studies (SOAS). ${ }^{18}$

With the outbreak of the Second World War, the need for foreign language skills increased dramatically. Initially the British Government was reluctant to fully utilise the University to train military personnel, but by 1943 SOAS was recognized as the primary institution in United Kingdom for Oriental and African languages. Over one thousand members of the armed services were trained at SOAS between 1943 and $1945 .{ }^{19}$ By the end of the War the School had proven itself an invaluable institution and had made a strong case for increased government funding to meet the changing requirements of the 
Post-War period. Cyril Henry Phillips, who became a lecturer at SOAS in 1936, Professor in Oriental History and head of the History Department from 1946 to 1980 , and who also served as Director of SOAS between 1957 and 1976, pointed out the context in which the proposal for increased government support was met:

The movement of world affairs, the ebb and flow of British fortunes, favoured the proposal, and the great changes brought about by the war in Asia and Africa, and the implications of the wartime alliance with Russia had made it urgently necessary to make a fresh appraisal of Britain's relation to these areas. ${ }^{20}$

The British Government received SOAS's proposal favourably, and Mr Anthony Eden, Secretary Of State for Foreign Affairs, authorised the establishment of a commission under the chairmanship of Lord Scarbrough to examine the current state of Oriental and African studies in the United Kingdom and to provide recommendations for their improvement. ${ }^{21}$ The Commission began work in 1945 and presented its findings to the Government in April 1946. The Report of the Interdepartmental Commission of Enquiry on Oriental, Slavonic, East European and African Studies, or the Scarbrough Report as it was known, was subsequently published in 1947.

\section{The Scarbrough Report}

The Scarbrough Report was a milestone in the development of the future discipline of African History, more for what it identified as the way forward in the fields of Oriental, Slavonic, East European and African Studies, than for what it practically achieved. The most important accomplishment made by the authors of the Scarbrough Report was the recognition that the study of the people and regions of Asia, the Soviet Union, Eastern Europe, and the Colonial Empire, were fundamentally important for British security and economic growth. As Chapter Three, 'The National Importance of These Studies', of the Scarbrough Report states:

a nation which does not possess a sound foundation of scholarship is ill-equipped to deal with world affairs, for scholarship is the source from which a knowledge of other countries and an interest in their ways of living is spread among the people. At a time when great efforts are being undertaken to make co-operation between the nations the basis of world peace and future prosperity this foundation of scholarship has an importance which cannot be disregarded without injury to the national and to international and to imperial interest. ${ }^{22}$ 
By identifying the need for future academic enquiry into foreign peoples, the Scarbrough Report single-handedly created the foundation for the subsequent development of African History in British Universities.

The Scarbrough Report acknowledged that non-linguistic African Studies was almost non-existent in the United Kingdom. It recommended the 'building up of an academic tradition comparable in quality and in continuity with those of the major humanities and sciences, ${ }^{23}$ and suggested that facilities for linguistic and non-linguistic study of Africa should be developed with urgency across the United Kingdom. To create an academic tradition in Oriental, Slavonic, East European and African Studies required new students and academics who would become specialists in these fields of study. ${ }^{24}$ Without the expansion of departments, new students and trained specialists, no expansion of knowledge in these new subjects could be undertaken. The Report recommended twenty studentships in African Languages and thirty studentships in nonlinguistic African Studies for young students who might be trained to hold junior academic posts. ${ }^{25}$ In addition, the Scarbrough Report made provision for grants to expand the staffing of university departments and centres of study: 'On a very rough estimate, the additional annual expenditure which the Universities as a whole would need to incur might be of the order of $£ 225,000$ at the end of five years, and a further $£ 225,000$ at the end of ten years'. ${ }^{26}$

The Scarbrough Report recognised the importance of expanding the largest English institution, the SOAS, into a world leader in Asian, African, Slavonic and East European studies. ${ }^{27}$ While expansion at SOAS included the provision for non-linguistic study this was secondary to the continuation of its role as the dominant institution where African languages could be studied in the United Kingdom. ${ }^{28}$ The importance placed on language study by the authors of the Scarbrough Report and SOAS can be seen in the provisions made for future staff levels at SOAS. The Director of SOAS submitted a proposal to the Scarbrough Commission to expand staffing levels for African Studies from $1944 / 45$ to $1960 .^{29}$ These recommendations specify a remarkable increase in staff numbers considering that at the time there were only six staff in the African studies department. The Scarbrough Report accepted the proposed increase at SOAS from six staff to forty-eight over sixteen years, and recommended that they 'be accepted in their entirety'. ${ }^{30}$ With provision made for only two lecturers in Anthropology and two Lecturers in African History and Law during the sixteen year period, it is clear that African language was considered paramount at SOAS (see Table 1). ${ }^{31}$ 


\section{Table 1. Proposed Staff Requirements for the School of Oriental and} African Studies, from 1944/45 to 1960.

Professors (two of Bantu and two of West African languages) 4

Readers in Swahili, Bantu languages, Hausa, and West African Languages 4

$\begin{array}{ll}\text { Lecturers in individual languages } & 21\end{array}$

Readers or Senior Lecturers in Anthropology 2

Lecturers in African History and Law 2

Reserve of lecturers (to allow for field research) 5

$\begin{array}{ll}\text { African Assistants } & 10\end{array}$

Total Staff 48

Source: Foreign Office, Report of the Interdepartmental Commission of Enquiry on Oriental, Slavonic, East European and African Studies, London, 1947, p. 142.

In addition, the Report recommended that non-linguistic studies on Africa, or as it was labelled in the report 'Colonial Studies', should be developed in the Universities of London, Oxford and Cambridge. ${ }^{32}$ The authors also hoped to foster an interest in African studies at ' $[\mathrm{t}]$ wo other universities, one in Scotland and one in the north of England'. ${ }^{33}$ The Institute of Colonial Studies at Oxford University was encouraged under the leadership of Margery Perham, a noted historian of Colonial Africa and Reader in Colonial Administration, to 'direct attention to the problems of the Colonial Empire'. ${ }^{4}$ Likewise, Cambridge University was encouraged to expand studies on African subjects and build upon the expertise of Professor E. A. Walker, who was the current holder of the Vere Harmsworth Professorship of Imperial and Naval History at Cambridge University and was well known for his interest in Africa. ${ }^{35}$ The institutions at Oxford and Cambridge were encouraged to build upon their existing strengths in Colonial Studies, particularly that of Anthropology, which was at the time considered essential for those who sought careers in Africa. ${ }^{36}$

The milestone Scarbrough Report of 1947 marks one of the most important developments in the creation of the discipline of African History. This report acknowledged that Africa and its peoples were a valid area of concern worthy of academic study in universities of the United Kingdom. Without this government recognition, African Studies and the discipline of African History would not have been 
funded and most likely would not have been established as a permanent subject within British institutions of higher learning in the next decade.

\section{The development of African History in the United Kingdom, 1947-1957}

Between 1947 and 1957 the growth in academic infrastructure promoted by the Scarbrough Report, albeit modest, guaranteed the future development of African History in the United Kingdom. While the Scarbrough Report intended to 'increase the development of non-linguistic subjects, which had been hitherto neglected', the actual institutional increases of the Scarbrough Commission's recommendations were limited. ${ }^{37}$ In 1952, after only five years, the University Grants Committee stopped the provision of specific grants for Oriental, Slavonic, East European and African Studies put in place by the Commission. From 1952 onwards African Studies departments had to compete with other more established subjects for their share of funding. ${ }^{38}$ The reduction of earmarked grants hindered the implementation of the Scarbrough Report's recommendations with the majority of the funding during the $1950 \mathrm{~s}$ going to SOAS. ${ }^{39}$ By 1960 SOAS had twenty staff, with less than a dozen African specialists and, as John Fage remarked, 'was to all intents and purposes no more than a department of African languages'. ${ }^{40}$ Yet despite Fage's claim, the impact of the Scarbrough Report to African studies during the late 1940s and 1950s was considerably greater than the funding of an African language department at SOAS.

The Scarbrough Report promoted interest in Africa and prompted the growth of academic enquiry in the late 1940s and throughout the 1950s. These years were so crucial to the full emergence of the discipline that Jan Vansina, one of the foremost Africanist scholars, claimed in his 1994 autobiography that African History had achieved academic acceptance marked by the independence of Ghana in $1957 .{ }^{41}$ Vansina noted that in order to reach academic credibility the discipline had to achieve three key objectives: 'A sufficient number of historians of Africa had to be recruited, an African history curriculum had to be set up, and it had to be shown that valid and usable sources were available for practitioners to write "indigenous history", ${ }^{4}$

In order to recruit historians, academic posts had to be created and a pioneering generation of African historians had to step up to recognise the potential of an Africanist history. The first generation of English scholars who wrote about Africa, like John Fage, Roland Oliver and John Blake, were not trained Africanists. ${ }^{43}$ That is, they 
were not trained to present African History from an African perspective. For example, during the 1930s Blake trained in Imperial History as a pupil of Arthur Newton, the Rhodes Professor of Imperial History at Oxford. A decade earlier, Newton, the then Professor of Imperial History in the University of London, made the remarkable statement that Africa had 'no history before the coming of the Europeans'. ${ }^{44}$ Thus, in the first half of the twentieth century, the first English academics writing on Africa, like Blake, worked within an educational framework steeped in an imperialist view that considered Africa as an integral part of the story of European nations, not as a continent with innumerable histories of its own. ${ }^{45}$ As a result, throughout the 1930s and early 1940s, publications on Africa were primarily the story of European enterprise in Africa. Yet scholars like Blake had realised by the late 1940s that a process of change was in motion, and had acknowledged that the time had come to write a history of Africa from an African perspective, albeit at this stage primarily reconstructed from European records. ${ }^{46}$

In 1948 Roland Oliver was appointed as the first lecturer in the Tribal History of East Africa at the School of Oriental and African Studies in London. This key appointment reflected the landmark shift in perspective that had occurred in recognising that Africa had its own history. This lectureship was made possible by the provision of funding generated by the Scarbrough Report. Oliver's appointment was immediately followed by his field research in East Africa between 1949 and 1950, after which he concluded that Ugandan history could be studied several centuries before the arrival of Europeans, a fact that hitherto had not been considered possible in academic circles. ${ }^{47}$ During his fieldwork Oliver learned the importance of interdisciplinary cooperation, and on his arrival back in England he presented oral traditions as legitimate historical sources. ${ }^{48}$ Oliver's appointment in 1948 was followed in the same year by the development of African university institutions, administered by SOAS. John Fage's appointment in 1949 as a lecturer in history at the University College of the Gold Coast, formally Achimota College, was the result of funding called for by the Scarbrough Report and the relationship of SOAS to African institutions. While in Africa, Fage, like Oliver, had realised that there was a rich local African history waiting to be researched and revealed, and alongside several prominent social anthropologists began to champion the introduction of African history courses. ${ }^{49}$

The two pioneering fathers of the discipline, Roland Oliver and John Fage, played a pivotal role in establishing the burgeoning subject of African History. ${ }^{50}$ Both 
Oliver and Fage acknowledged the need for cooperation between historians, archaeologists and anthropologists. ${ }^{51}$ Throughout 1951 and 1952 Fage and Oliver met and conceived the First Conference on African History and Archaeology, which was held in 1953 at SOAS. ${ }^{52}$ The conference brought together academics from a wide range of disciplines and was subsequently described by Oliver in his 1997 autobiography as having put African History on the map. ${ }^{53}$ This was the first ever international conference designed to bring history teachers from all of the African university colleges together alongside international scholars. It's central topic of discussion was the urgent task of advancing pre-European African history. ${ }^{54}$ Discussion centred on how oral traditions, archaeological remains and written records might be used to reconstruct the African past. Historians at the conference realised that the minimal written evidence available from largely pre-literate West-African societies meant that to uncover the precolonial past alternative evidence had to be garnered. To counter the claims of sceptics within the academy, historians of Africa had to prove, as Vansina claimed, that there were enough accurate sources to present indigenous history, and importantly that this history existed for pre-colonial Africa. The success of this conference can be measured by the fact that Fage subsequently implemented African history courses at the University of the Gold Coast between 1953 and $1954 .{ }^{55}$

While the 1953 conference had opened the way for academic interdisciplinary cooperation, the 1957 conference set about making the future direction of African History a reality. The proceedings for the 1953 and 1957 conferences were each subsequently published. ${ }^{56}$ Both of these reveal that the focal point of these seminars were centred around the methodological problems confronting historians and archaeologists. The 1957 conference held at SOAS, like its pioneering 1953 predecessor, was fundamentally important for emphasizing that the future of African History as a subject of study relied on combining various types of source material. ${ }^{57}$ The 1957 conference urged the immediate need to train historians 'for fieldwork in Africa in concert with archaeologists and anthropologists'. ${ }^{58}$ According to Vansina, who attended the 1957 conference, oral tradition was discussed at length in the proceedings and singled out as an important area for continued attention. ${ }^{59}$ Vansina considered the two groundbreaking conferences in the 1950s on African History and Archaeology as evidence of the acceptance of African History's legitimacy as an academic subject. ${ }^{60}$ Both Vansina and Fage, writing in the 1990s, reflected on how historians of tropical Africa doubled between 1953 and 1957, with thirty-three papers submitted in the first 
conference and seventy in the second. ${ }^{61}$ However, aside from conferences, there was still no real forum for the academic sharing of multidisciplinary information.

Between 1948 and 1957 attempts at the integration of a multidisciplinary history of Africa had been undertaken by specific university departments in the United Kingdom and Africa. At SOAS, Roland Oliver's role was to 'address the much wider question of how African history could be developed into a regular subject of study, not only in London but also in the emerging university colleges in tropical Africa that were preparing their students for London University degrees' ${ }^{62}$ Integral to the development of the emerging discipline was the need to supervise postgraduate students who would ultimately go on to teach African history from an Africanist perspective. The difficulty in training students in African subjects in the United Kingdom was that they were constrained by limited funding. Furthermore, in a three-year postgraduate course students could not develop adequate African language skills. ${ }^{63}$ In his 1997 autobiography Oliver claimed that the ultimate result of this was that postgraduate students were restricted to writing African history from European records. ${ }^{64}$

Evidence of the dependence on European sources can be seen in the details of postgraduate theses produced and the research undertaken in African subjects. James Coleman investigated the current state of Africanist research in 1959 within the United Kingdom, and concluded that the discipline had progressed along a multidisciplinary path combining anthropology, sociology and history. ${ }^{65}$ Coleman noted that ' 51 of the 72 Ph.D. dissertations completed in British universities during the period 1950-1956' and '79 of the 107 current research projects' on African subjects were in anthropology, sociology and history. ${ }^{66}$ However, the pattern of this growth shows that while African academics who studied history were on the increase, by 1957 anthropology, not history, dominated the field work in Africa and retained the largest number of Ph.D. students. ${ }^{67}$ Between 1950 and 1956 the number of Ph.D. students in anthropology was three times greater than those in history. In sum, the number of postgraduate students studying African topics in the United Kingdom during this period were: forty studying anthropology; eleven in history; six for political science and law; five for linguistics; five in economics; and five in geography.

It is particularly striking that, despite the growth of postgraduate interest in African subjects between 1948 and 1957, few students produced theses that considered an African perspective of events for pre-colonial Africa ca.1450-1800. Of the sixty-six students who completed an M.A. or Ph.D. thesis on African subjects up until and 
including 1957, only thirteen can be considered as pre-1800 histories. ${ }^{68}$ Of these, only ten theses were on subjects directly about African peoples removed from European contact: one for Tanganyika in Central Africa; one for Ethiopia; and eight for Egypt. Furthermore, all of the theses related to ancient and medieval history prior to $1450 .{ }^{69}$ During the first ten years of the development of the discipline, then, postgraduate attention was mainly directed at African histories that could be researched from written records held in European archives.

One striking exception to scholars' continued reliance on written European records was the British trained Nigerian academic Kenneth Onwuka Dike, who received his Ph.D. from the University of London in 1950. Much has been written in retrospect about the importance of Dike's thesis 'Trade and Politics in the Niger Delta, 18301879', published in 1956. Dike's work reflected the growing assertion in the 1950s that African history could be presented in its own right. ${ }^{70}$ Ajayi, writing about Dike, claimed he:

was the first to get [oral evidence] accepted as part of a scholarly work for a doctorate, and it was not easy then to get a supervisor or the relevant University Committee to agree to it. That is why his resultant work Trade and Politics in the Niger Delta marks and important milestone in the evolution of historiography not only in Africa, but also generally. ${ }^{71}$

While not exclusively a work which utilised oral sources, Dike did incorporate traditional histories throughout his first chapter, 'The Pattern of West African Trade and Politics, 1481-1830 and his second chapter, 'The Delta and its People'. ${ }^{72}$ In doing so Dike promoted the case that African oral evidence could be examined alongside that of European written material. The success of Dike's revolutionary approach can be seen in the fact that he championed the introduction of African history courses at the University College of Ibadan (Nigeria). Until 1956, the University of London had only permitted the University College of Ibadan to teach the history of Europeans in Africa. ${ }^{73}$

The acceptance of African History was achieved by 1957 through the crucial acknowledgment by scholars in the value of an interdisciplinary approach towards the reconstruction of the African past. Revealing the pre-colonial past was the key factor required for historians to present an Africanist history, and the lack of pre-colonial sources necessitated interdisciplinary skills. Historians, particularly those teaching in African universities, were beginning to turn their attention to pre-colonial history, a point reinforced by the success of the 1953 and 1957 conferences on African History 
and Archaeology at SOAS. It was due to the pioneering work done between the two conferences that teams of academics from different disciplines were able to work together on similar projects. One such project was the 'Scheme for the Study of Benin History and Culture', launched in 1956 under the direction of Kenneth Dike. Since completing his Ph.D. dissertation, Dike had returned to Nigeria and joined the History Department of the University College, Ibadan. After working at the West African Institute for Social and Economic Research between 1952 and 1954 he returned to the university and in 1956 was awarded a Professorship and the chair of the History Department. $^{74}$

Dike's Benin project sought to integrate the findings of various interdisciplinary fields in order to recreate the history of Benin, an African kingdom which flourished from the tenth century until conquered by the British in the late-nineteenth century. However, while there were interesting points made, the ultimate goal of an integrated picture of Benin's history was not achieved. Robert July, looking back on the Benin project in 1987, wrote that:

[m]uch information and experience was gained, particularly with the complexities of a multidimensional project. Written records of European origin, local oral traditions, the sociology of contemporary Benin, and the material remains of the past were all studied in detail and with profit. Difficulties arose, however, in relating information from different sources to form a coherent integrated picture of the past. No single person appeared capable of absorbing such diverse materials to produce one synthetic whole. ${ }^{75}$

According to July, the major stumbling block to interdisciplinary cooperation was the complexity involved in understanding other disciplines' methodologies and to satisfactorily express both. Despite the best intentions of academics to grasp the complexities of other disciplinary methods it was clear that by the late 1950s the intended interdisciplinary cooperation on the Benin project was not successfully achieved. For example, Alan Ryder, who worked on Dike's Benin Scheme, went on to write Benin and the Europeans, 1485-1897 in 1969, a work that failed to use an interdisciplinary approach and relied predominantly on archival records. ${ }^{76}$

The failure of interdisciplinary cooperation was especially true in the presentation of pre-colonial African history, an essential area of study for the emerging discipline. The recovery and presentation of pre-colonial African history was required to prove that Africans had a history of their own before the arrival of Europeans. The difficulty in presenting a total picture of history for any area of pre-colonial Africa during the $1950 \mathrm{~s}$ 
was directly attributable to the lack of comprehensive evidence available in any one particular type of source. The reconstruction of the African past, according to Roland Oliver, was not related to the scarcity of sources, rather, African historians would need training in numerous languages. One would need to read:

English, French, Arabic, Portuguese, Dutch, German, Italian, Afrikaans, Amharic, Greek Latin and Ancient Egyptian, [Spanish] to name only the most important. The unwritten lore of pre-colonial times has to be recovered from peoples speaking some six or seven hundred languages. The archaeological approach, beginning with man's origins and before, continuing right up to the eve of the colonial period, requires as many skills as the historical. ${ }^{77}$

With the historian of Africa requiring competency in European languages, the appropriate African languages, and an understanding of archaeological methods, it is little wonder that the majority of historians during the 1950s reconstructed African history mainly from the European archival record. ${ }^{78}$

It is also understandable that the colonial period dominated publications on Africa during the 1950s. While historians were being trained in new approaches the more plentiful written records of the colonial period offered instantaneous sources. Where adequate written materials existed there was little cross-disciplinary work required to reconstruct an account of past events. It was the lack of written African sources that created difficulty in the training of historians in a new type of African History, and ultimately the problematic nature of source material would influence the presentation of the African past.

During the period from 1948 to 1957, anthropologists, archaeologists, linguists and historians wrote and researched Africa within their own given fields, met to discuss their findings at conferences, and published their ideas in journals. Despite relatively few numbers of Africanist historical theses during the 1950s that covered the precolonial period of African history, dramatic growth had been achieved in the recognition that multidisciplinary cooperation was required in the subject. In the case of most postgraduates their theses concerned the better known regions such as North Africa, the coastal regions of West Africa and South Africa, where there was considerable European contact, and usually focused on the late-nineteenth century. In hindsight, the 1950s can be seen as a transitional point in the development of the discipline, and while Vansina's claim that that the discipline had come into academic acceptance by 1957 is valid, the discipline had not yet resolved its interdisciplinary methodological dilemma. According to Vansina in his 1994 autobiography, by 1960 
none of the various interdisciplinary schemes were successful in creating a multidisciplinary reconstruction of the past. ${ }^{79}$

However, the decision at the 1957 conference to create the Journal of African History and its subsequent publication since 1960 went in some way to rectifying the need for a cross-disciplinary approach. The Journal of African History provided a forum for historians and specialists in the field. The success of the 1953 and the 1957 conferences and the growth in the numbers of African historians led directly to the Rockefeller Fund's decision to financially assist the creation of the Journal of African History with John Fage and Roland Oliver as its founding editors. ${ }^{80}$ The foundation of the journal was described by Philip Curtin, a well-known pioneering American historian of Africa, as 'the coming-of-age' of African History. ${ }^{81}$ What made the Journal of African History so important was that it was the first journal dedicated to publishing multidisciplinary articles on the history of Africa and its people, focusing on an Africanist perspective. Terrance Ranger, a respected Africanist historian, paid tribute to the foundation of the Journal of African History at the 1974 University of Edinburgh conference 'African Studies since 1945', where he noted that the journal championed the now accepted multidisciplinary approach to the African past. ${ }^{82}$

While the Journal of African History enabled publication in one place of multidisciplinary investigation into African history, its role remained more as a forum for knowledge than a tool of interdisciplinary training. The journal's strength lies solely in its ability to present African history to a wide readership. To Jan Vansina, writing in 1995, the attempts to integrate oral and archaeological evidence into the historical discipline of African History have still not been satisfactorily achieved, and despite the valiant efforts of the Journal of African History, African History and archaeology remained divided largely due to the difficulty of integrating the findings into a meaningful historical account. ${ }^{83}$ One example of an attempt to share disciplinary findings in the Journal of African History can be seen in the constant revisions to radiocarbon dating in pre-colonial Africa. Between 1960 and 2002 the journal published twenty-four articles on radiocarbon dating, each updating artifactual evidence. ${ }^{84}$ This dating provides some useful information for reconstructing the chronological framework for African civilisations, but due to its non-absolute nature, exact dating is difficult and thus is problematic for use by historians. The problem of interdisciplinary cooperation is that it requires considerable cross-training between fields that are often incompatible. 
Between 1947 and 1957 historians attempted a new interdisciplinary approach to reconstructing the African past. The discipline aimed to consider an African perspective from a multitude of sources, something unthinkable before the Second World War. With the 1957 conference on African History and Archaeology the discipline of African History had achieved a sense of legitimacy. Courses and methodologies were being established that would culminate in a massive growth in the study of African History in the 1960s. African History was on the threshold of what historian Terrance Ranger considered to be the 'Golden Age' of African History. ${ }^{85}$

\section{The Hayter and Robbins Reports, 1961-1963}

While African History established itself throughout the 1950s, two official government reports guaranteed the infrastructural support required for the fledgling discipline in the 1960s. The first of these was published in 1961 by the University Grants Committee, Report of the Sub-Committee on Oriental, Slavonic, East European and African Studies, known as the Hayter Report. The authors of the report acknowledged the fundamental contribution of the Scarbrough Report to all subsequent developments in African Studies in the United Kingdom, yet, at the same time, the Report noted that political changes rather than the recommendations of the Scarbrough Commission had increased the study of Africa in British institutions. ${ }^{86}$ The Hayter Report outlined that between 1947 and 1961 there had been considerable improvement in non-linguistic African Studies but that the level of improvement was still insufficient and did 'not reflect the comparative importance demographically, politically or economically of these areas' ${ }^{87}$ The Report acknowledged that there was a strategic importance in the development of African Studies and noted that the authors of the Scarbrough Report had been justified in their recommendations for the immediate increase in Oriental, Slavonic, East European and African Studies. ${ }^{88}$ The Hayter Report was published at a time when decolonisation had resulted in creating 'seven newly independent territories, four in Asia and three in Africa, and more on the verge of independence'. ${ }^{89}$ The authors of the Hayter Report saw that the need for African Studies in English universities was as great in 1961 as it had been in $1947 .^{90}$

The Hayter Report fostered the growth of a solid infrastructure for the expansion of African Studies and importantly the development of African History as a discipline 
throughout the 1960s. John Fage gives a good overview of the important recommendations of the Hayter Report:

A further dose of Scarbrough-type medicine was urgently needed to expand the total quantity of university research into these areas, 'to increase the number of students outside the language departments who come into contact with the ideas, history and problems of the non-western world', and 'to achieve a better balance between linguistic and non-linguistic studies and between classical and modern studies'. To this end it was recommended that over the ten years 1962-71 earmarking should be resumed to create 125 new posts in the history, geography, economics, law, anthropology or other non-language aspects of the non-western world, or for posts in such fields which would be held jointly with language departments; to fund ten postgraduate studentships a year; and to support teaching and research relevant to the non-western world with adequate library resources and travel funds. ${ }^{91}$

The Hayter Report also recommended the setting up of 'Area Studies Centres', which resulted in the establishment of the Centre of West African Studies at the University of Birmingham (CWAS) and the Centre of African Studies at the University of Edinburgh in $1963 .{ }^{92}$ The formation of Area Studies Centres was influenced by a visit to the United States by members of the Hayter Commission. ${ }^{93}$ The intention behind the creation of these centres was that academics of different disciplines would gather to share sources and develop a well-rounded approach to the peoples and regions being studied. Fage states that, 'after Hayter had reported, it was interesting to notice that SOAS put alongside its departmental structure a framework of area studies centres, headed by chairmen drawn in rotation from the various disciplinary departments-albeit not from their heads'. ${ }^{94}$ According to Fage, the Hayter Report also led to the creation of the independent African Studies Association of the United Kingdom by Roland Oliver and Antony Allott in $1963 .{ }^{95}$

In 1963 the British government, via the Robbins Report, further strengthened the infrastructure supporting African Studies. The 1963 Report of the Committee appointed by the Prime Minister under the Chairmanship of Lord Robbins, 1961-63 (Higher Education) (Cmd. 2154) prompted a large growth in higher education and an increase in staff. ${ }^{96}$ The Robbins Report conducted a review of the entire higher education system in the United Kingdom and recommended that student numbers be increased from 216,000 in $1962 / 63$ to 560,000 in $1980 / 81 .^{97}$ The Committee was not far off the mark: by 1981 there were 533,000 students in higher education in the United Kingdom. ${ }^{98}$ In order to cope with the planned increase in students, the Report recommended an increase in 
staffing to maintain, and if possible increase, the ratio of teachers to students. ${ }^{99}$ According to Fage, '[b]y the 1960s, especially perhaps with the implementation of the Robbins Report after 1963, substantial numbers of British academics with experience in Africa were finding their way onto the teaching and research staffs of the UK universities'. ${ }^{100}$

Table 2 contains a list of academics who worked in African universities who went on to hold major academic posts. For the most part this table is concerned with universities in the United Kingdom and English scholars. The exceptions are Andrew Roberts, Graham Irwin, John Omer-Cooper, Ivor Wilks and Jack Lander. Roberts, an American, spent his entire career after Dar Es Salaam teaching at SOAS, and Graham Irwin, an Australian educated in Britain, was John Fage's successor in Ghana before heading the African Studies department at Columbia University. Omer-Cooper, a South African who shifted to New Zealand to escape an attempt on his life, was the former head of the history department at the University of Zambia. He effectively established African History as a subject in New Zealand at Otago University. Wilks, a pioneer of African oral history, taught for over two decades at Northwestern University in Chicago, and Landers, an English medieval historian, was a prominent historian in Africa before going to Canada. Like Landers, not all of the people in the table went on to teach African History. For example, Patrick Collinson was an ecclesiastical historian of England and Jack Scarisbrook was an English medievalist. Robert Gavin and Eric Stokes produced some African history, but Gavin predominantly worked on English and Irish history and Stokes became a major historian of India at Cambridge. Roger Anstey and Richard Gray were former students of Roland Oliver and Andrew Roberts a past student of Jan Vansina. Importantly all of these historians were serving in Africa between 1950 and 1970, the crucial years of the discipline's development.

The expansion of the supporting infrastructure of higher education driven by the Robbins Report helped to bring historians who had trained in Africa into history departments across the United Kingdom. These new lecturers carried their expertise on Africa, as Fage recollected, not only into African departments but also into 'straightforward disciplinary departments', such as History. As Fage stated in 1989, 'I can think of nine historians who had held expatriate posts in the African colleges who subsequently held UK chairs of Modern History; this compares with six who have held UK chairs of African or Imperial History'. ${ }^{101}$ Importantly these historians brought with them from service in Africa a developed sense that Africa had a rich historical past 
Table 2. Historians who have held senior positions after service in African Universities.

\section{Chairs of Modern History in the UK}

$\begin{array}{ll}\text { Roger Anstey } & 1952-59, \text { Ibadan, Nigeria } \\ \text { David Birmingham } & 1960 \text { s, Ghana } \\ \text { Patrick Collinson } & 1956-61, \text { Khartoum, Sudan }\end{array}$

Paul Hair

1953-65, Khartoum \& Ibadan

John Hargreaves

1952-54, Fourah Bay, S. Leone

Kenneth Ingham

Terence Ranger

G. N. Sanderson

Jack Scarisbrick

\section{Posts in Universities}

$\begin{array}{ll}\text { Jack Lander } & \text { 1950s-60s, Ghana } \\ \text { John Omer-Cooper } & \begin{array}{l}\text { 1950s-60s, Ibadan } \\ 1966-73, \text { Zambia }\end{array}\end{array}$

\section{Posts in UK Polytechnics}

Oliver Furley

1957-60s, Makerere

Robert Gavin
1968-79, University of Kent 1980-2001, U. Kent 1976-84, U. Kent 1984-97, Sheffield 1988-96, Cambridge 1965-90, [Chair 1979] Liverpool 1954-85, [Chair 1962] Aberdeen 1967-86, Bristol 1974-87, Manchester 1987-97, Oxford 1965-84, Royal Holloway College 1969-94, Warwick

1960s-1986, University of Western Ontario 1974-1997, Otago, New Zealand

1970s-current, Coventry 1980s-90s, Ulster

\section{Chairs of African or Imperial History}

John Fage

1949-59, Ghana

Richard Gray

Anthony Low

1959-61, Khartoum

1951-60, Makerere

Andrew Roberts

Eric Stokes

Graham Irwin

Ivor Wilks 1960s-70s, Dar es Salaam 1950s-60s, Rhodesia 1959-65, Ghana 1953-66, Ghana

\author{
1959-63 SOAS \\ 1963-84, Birmingham \\ 1961-89, SOAS \\ 1968-71, Sussex \\ 1983-84, Cambridge \\ 1970s-90s, SOAS \\ 1963-81, Cambridge \\ 1974-83, Columbia \\ 1971-93, Northwestern
}

Source: J. D. Fage, 'British African Studies since the Second World War: A Personal Account', African Affairs, Vol. 88, No. 352, July, 1989, p. 406. 
before the arrival of Europeans and the essential need to produce African History that recognized an African point of view. Through the assistance of the Hayter and Robbins Reports, these British academics in Africa returned to expand the teaching of African History to the succeeding generation of Africanist historians.

The achievements of Roland Oliver and John Fage were recognised in 1963 with both men being promoted to full Professor, Oliver receiving the first established Chair of African History at SOAS in London and Fage receiving a personal Chair in African History and the Directorship of CWAS in Birmingham. ${ }^{102}$ CWAS, under the directorship of John Fage, would develop to be one of the top three African Studies centres in the English-speaking world, alongside SOAS under Roland Oliver in London, and the University of Wisconsin, under Philip Curtin and Jan Vansina. Roland Oliver and John Fage, as benefactors of government support, duly expanded the new field of African History at SOAS and CWAS. In a large part, the success of the discipline's growth in the United Kingdom is attributable to them, particularly as they influenced the next generation of graduate students in the discipline of African History.

In the 1980s, special editions of the Journal of African History paid tribute to Oliver's and Fage's efforts in building the discipline of African History. Michael Crowder noted that under Oliver's direction at SOAS many graduates were trained who would go on to:

staff history departments in the new African universities, or to set up African history programmes in American universities. By the time Roland retired in 1986, he had supervised forty-two theses on a wide variety of aspects of sub-Saharan African history, with a particular concentration on Eastern Africa. Perhaps most striking of all was that a quarter of these theses were primarily based on oral tradition rather than documentary sources. It is a testimony to the high standards on which he insisted that twenty-six out of these forty-two theses have been published. And even when he retired he took with him to his home in Frilsham the supervision of a last thesis, concerned with the early twentieth-century history of Namibia. Among those students he has supervised have been a large number of Africans, some of whom, like Adu Boahen, were to establish their own graduate schools. ${ }^{103}$

John Fage was also paid tribute to in a special edition of the Journal of African History in $1986 .{ }^{104}$ The invited authors, his former students, noted his enormous contribution as a teacher and tireless promoter of African History. Douglas Rimmer, Fage's eventual successor as Director at CWAS, pointed out that Fage, in his role as Director of CWAS for over twenty years, 'appeared always to give priority to teaching, whether it was the 
supervision of his research students or the course introducing the history of the African continent which he taught for nearly 20 years to first-year undergraduates' ${ }^{105}$ By his retirement in 1984, Fage had supervised twenty doctoral students, the most prominent of whom were: Robin Law (Professor of History, University of Stirling); Robin Cohen (Professor of Sociology, Warwick University); Finn Fuglestad (Professor of History, Oslo University); and Adam Jones (Professor of History, University of Leipzig). ${ }^{106}$

By 1963, African History as a discipline was institutionalised as an accepted part of the academic curriculum in the United Kingdom and Africa, supported by an elaborate educational infrastructure. The Hayter and Robbins Reports recognized the recommendations of the Scarbrough Report and provided a solid foundation for the budding discipline. With the provision of funding and the experience of working in Africa, English academics spread African History throughout the United Kingdom. The fact that many of the scholars who taught in Africa went on to hold senior academic posts is directly attributable to their success in developing the discipline and the infrastructural support received from the Hayter and Robbins reports.<smiles>C1CC12CC2</smiles>

Reflecting on the genesis of the discipline in 1989, well after his retirement, John Fage believed that the Scarbrough Report of 1947 and the creation of African universities in 1948 were seminal moments in the discipline. Indeed, the academic infrastructure developed in Britain in parallel to the growth of African higher education, as discussed in chapter one. Together, these two events guaranteed the establishment of African History as an academic subject in British universities in Africa and the United Kingdom. The creation of the modern discipline of African History in the United Kingdom was the outcome of a continuous pattern of educational development supported by the growth of an infrastructure promoted at first by missionaries, private institutions and then established formally by a succession of government reports. The growth of SOAS in the 1940s and 1950s, established in Britain a solid foundation from which all subsequent developments in African Studies could take place. While the 1947 Scarbrough Report was pivotal in establishing the future direction of African Studies and promoting government support for the expansion of educational facilities, the Hayter Report in 1961 continued the direction of the Scarbrough Commission and helped to promote facilities for the study of Africa, such as CWAS. The Hayter Report, like the Scarbrough Report, was a product of the gradual process of decolonisation and 
essential for establishing a platform for African Studies in the United Kingdom. In 1963 the Robbins Report, in turn, strengthened higher education and increased the funding of university departments. The Robbins Report enabled the appointment of prominent African historians to positions in the United Kingdom who would subsequently drive the development of the discipline of African History through the establishment of programmes and graduate training. 


\section{Notes to Chapter Two}

${ }^{1}$ Foreign Office, The Report of the Interdepartmental Commission of Enquiry on Oriental, Slavonic, East European and African Studies, London: H.M.S.O., 1947, Reprint 1959, (Scarbrough Report).

${ }^{2}$ University Grants Committee, Report of the Sub-Committee on Oriental, Slavonic, East European and African Studies, London: H.M.S.O., 1961, (Hayter Report); Cmd. 2154, (Higher Education) Report of the Committee appointed by the Prime Minister under the Chairmanship of Lord Robbins, 1961-63, London: H.M.S.O., 1963, (Robbins Report).

${ }^{3}$ For a good history of the association see Robin Hallett, (ed.), Records of the African Association, Edinburgh: Nelson, 1964.

${ }^{4}$ The Journal of the Royal Geographic Society of London was founded in 1831 and published by John Murray, London. In 1881 this became the Proceedings of the Royal Geographical Society and Monthly Record of Geography. This journal unlike the Journal of the Royal African Society, was not devoted explicitly to African societies but rather to the scientific study of geography.

${ }^{5}$ The Journal of the Royal African Society was started in 1901 and published by the University of Oxford. In 1944 it became the Journal of African Affairs. The inaugural volume in 1901 contained an article on the African Association by William Sinclair, 'The African Association of 1788', Journal of the Royal African Society, Vol. 1, No. 1, October, 1901, pp. 145-149. It also contained an article on Mary Kingsley, Alice Stopford Green, 'Mary Kingsley', Journal of the Royal African Society, Vol. 1, No. 1, October, 1901, pp. 1-16. Mary Kingsley (b.1862d.1900) was a prolific writer on Africa. See the following books by Mary Kingsley: Travels in West Africa, Congo Français, Corisco and Cameroons London: Macmillan \& Co. Ltd., 1897; West African Studies, London: Macmillan \& Co. Ltd., 1899; The Story of West Africa, The Story of the Empire Series, London: Horace Marshall, 1900. Articles by Mary Kingsley: 'Life in West Africa', in W.M. Sheowring (ed.), The British Empire Series. Volume 2: British Africa, London: K. Paul, Trench, Trubner and Co., 1899, pp. 366-380; 'Nursing in West Africa', Chamber's Journal, June, 1900, pp. 369-371; 'Fishing in West Africa', National Review, May, 1896, pp. 213-227; 'Travels on the Western Coast of Equatorial Africa', Scottish Geographical Magazine, Vol. 12, March, 1896, pp. 113-124.

${ }^{6}$ Frederic Shelford, 'Some Notes on the History of the African Society', Journal of the Royal African Society, Vol. 34, No. 136, July 1935, pp. 223-226, see p. 224.

${ }^{7}$ Frederic Shelford's speech reproduced in 'The African Society Inaugural Meeting', Journal of the Royal African Society, Vol. 1, No. 1, October, 1901, pp. i-xx, see p. ix. Shelford was an active member of the society until his death. His contribution is duly noted in his obituary notice in the Journal of the Royal Society, see, Author Unknown, 'The Death of Captain F. Shelford', Journal of the Royal African Society, Vol. 42, No. 169, October, 1943, p. 182. This notice explains his founding role in the society and his experiences in Africa.

${ }^{8}$ Shelford's speech reproduced in 'The African Society Inaugural Meeting', see pp. x-xi.

${ }^{9}$ Ibid, pp. xi-xii.

${ }^{10}$ Author Unknown, 'Fifty Years of a British African Society', African Affairs, Vol. 50, No. 200, Jubilee, July, 1951, pp. 177-195.

${ }^{11}$ Ibid, p. 183; C.H. Phillips, The School of Oriental \& African Studies, University of London 1917-1967, London, School of Oriental \& African Studies, University of London, 1967, p. 24.

${ }^{12}$ The University of London was created in 1836 from an amalgam of the University College London founded in 1827 and Kings College founded in 1829.

${ }^{13}$ Phillips, The School of Oriental \& African Studies, pp. 9-14.

${ }^{14}$ Ibid, p.17.

${ }^{15}$ Ibid.

${ }^{16}$ Ibid, p. 23.

${ }^{17}$ Foreign Office, The Report of the Interdepartmental Commission of Enquiry on Oriental, Slavonic, East European and African Studies, London: H.M.S.O., 1947, reprint 1959, p. 138. 
${ }^{18}$ Funding from the Rockefeller Foundation enabled the creation of the African Department at SOAS.

${ }^{19}$ Phillips, The School of Oriental \& African Studies, p. 36.

${ }^{20}$ Ibid, p. 38.

${ }^{21}$ Foreign Office, The Report of the Interdepartmental Commission of Enquiry on Oriental, Slavonic, East European and African Studies, London: H.M.S.O., 1947, p. 5.

${ }^{22}$ Ibid, p. 24. For the whole context see Chapter III, 'The National Importance of these Studies', pp. 24-28.

${ }^{23}$ Ibid, pp. 15, 28 (quote).

${ }^{24}$ Ibid, Chapter IV, 'The Building up of an Academic Tradition', pp 28-46, Chapter V,

'Training for Careers', pp. 46-61.

${ }^{25}$ Ibid, pp. 39-40.

${ }^{26}$ Ibid, pp. 71-72. For a full explanation of the recommendations see Chapter VII, 'Summary of Recommendations', pp. 69-77.

${ }^{27}$ Ibid, pp. 164-165; Phillips, The School of Oriental \& African Studies, p. 39. Phillips wrote: ' $[t]$ he Scarbrough Report formed a milestone in the development of these studies in Britain'.

The book contains references to the importance and role of the Scarbrough Report from page 38 through to page 57 . Given that the book is only sixty six pages long in total the amount of space devoted to the Scarbrough Report. A good indication of the association SOAS had with the Report. See also Aim 25, Archives in London and the M25 area, 'School of Oriental and African Studies Archives', http://www.aim25.ac.uk/cgi-bin/search2?coll_id=2951\&inst_id=19, last accessed 21 August 2007, and [Sir Ralph L. Turner] R.L.T., 'Obituary: Lawrence Roger Lumley, 11th Earl of Scarbrough, K.G., P.C., G.C.S.I., G.C.I.E., G.C.V.O., 27 July 1896-29 June 1969', Bulletin of the School of Oriental and African Studies, University of London, Vol. 32, No. 3, 1969, pp. 686-689. Turner wrote, '[o]n the recommendations in the Commission's Report, which was submitted to the Secretary of State in April 1946, and published in 1947, the whole remarkable post-war development of Asian, African, Slavonic, and East European studies in the universities of the United Kingdom has been founded. More particularly, the building up of the School of Oriental and African Studies into an institution recognized throughout the world as occupying a unique and pre-eminent position in its fields of study is ascribable almost entirely to the wisdom of the recommendations of Lord Scarbrough'.

${ }^{28}$ Foreign Office, The Report of the Interdepartmental Commission of Enquiry on Oriental, Slavonic, East European and African Studies, London: H.M.S.O., 1947, reprint 1959, p. 137.

${ }^{29}$ Ibid, pp. 141, 165. The Director of SOAS submitted a report for the expansion of studies at SOAS for a period of sixteen years. The submission was originally submitted to the Court of the University in 1944, and forwarded to the Scarbrough Committee, 19 September 1945.

${ }^{30}$ Ibid, p. 170.

${ }^{31}$ Further indication of the prominence placed upon African language study over African History can be seen in that, twenty six years before the seminal appointment of Roland Oliver in 1948 as the first chair of African History in Britain, Alice Werner had been appointed as the first Professor of Swahili and Bantu languages in 1922. Werner began teaching African languages as a member of the informal African Association and went on to play a fundamental role in establishing the study of African languages within British universities. For a detailed biography of Werner see, Oxford Dictionary of National Biography, P.J.L. Frankl, 'Werner, Alice (1859-1935)', Oxford University Press, 2004; online edition, May 2006, http://www.oxforddnb.com/view/article/38117, last accessed 8 January 2008. See also [Charles Otto Blagden] C.O.B., 'Obituary: Professor Alice Werner', Bulletin of the School of Oriental Studies, University of London, Vol. 8, No. 1, 1935, pp. 281-282; Foreign Office, The Report of the Interdepartmental Commission of Enquiry on Oriental, Slavonic, East European and African Studies, London: H.M.S.O., 1947, reprint 1959, p. 137. The report noted, that it was upon the existing foundation of knowledge developed by people like Alice Werner at SOAS, that the Scarbrough Report recommended that SOAS continue to develop African language studies. 
${ }^{32}$ Foreign Office, The Report of the Interdepartmental Commission of Enquiry on Oriental, Slavonic, East European and African Studies, London: H.M.S.O., 1947, reprint 1959, p. 38. ${ }^{33}$ Ibid.

${ }^{34}$ Ibid, p. 145.

${ }^{35}$ Ibid, p. 147.

${ }^{36}$ Ibid, p. 144. The report states, '[a]part from generalised attention to colonial subjects, special attention attaches to the existence of active and well organised departments of anthropology. The reason is that Africa contains large numbers of primitive peoples whose customs and institutions as far as they have been scientifically studied, provide a considerable proportion of the material on which modern anthropological research and teaching are founded. There can, therefore, be no teaching of anthropology without imparting a great quantity of information about Africa and Africans. Moreover, it is true to say that of all the non-linguistic studies necessary for persons about to embark on careers in Africa anthropology, in its widest implications, takes high, if not absolute, priority'.

${ }^{37}$ University Grants Committee, Report of the Sub-Committee on Oriental, Slavonic, East European and African Studies, London: H.M.S.O., 1961. p. 9. The Report contains a review of the Scarbrough Report. See also the findings on p. 73, Table XIIA, which notes that out of the fifty studentships in African studies proposed by the Scarbrough Report by 1961, only fifteen were received. However, of these fifteen, twelve students completed and of these, nine were academically employed.

${ }^{38}$ Ibid, p. 22.

${ }^{39}$ Ibid, pp. 16-17. Between 1947 and 1961, SOAS received government funding and the support of private foundations in part due to the fact that it was the only institution teaching university courses in African languages. It is also worth noting that the Earl of Scarbrough served as the Chairman of the Governing Body of the School of Oriental \& African Studies from 1951 to 1959. See also J.D. Fage, 'British African Studies since the Second World War: A Personal Account', African Affairs, Vol. 88, No. 352, July, 1989, pp. 397-413, see p. 404.

${ }^{40}$ Fage, 'British African Studies since the Second World War: A Personal Account', p. 404. See also, University Grants Committee, Report of the Sub-Committee on Oriental, Slavonic, East European and African Studies, London: HMSO, 1961, p.18; C.H. Philips, 'Modern Asian Studies in the Universities of the United Kingdom', Modern Asian Studies, Vol. 1, No. 1, 1967, pp. 1-14, p. 2. Although Phillips and Fage note the shortcomings of the Scarbrough Report both authors recognise the importance of the report for leading to the later Hayter and Parker Reports for African studies and the Robbins Report for the expansion of higher education in Britain. ${ }^{41}$ Jan Vansina, Living with Africa, Madison, Wisconsin: The University of Wisconsin Press, 1994, p. 51. See also Philip D. Curtin, 'Third Conference On African History and Archaeology', African Studies Bulletin, Vol. 4, No. 3, October, 1961, pp. 10-11. Curtin, like Vansina, albeit writing thirty three years earlier, noted that in 1957 it was abundantly clear that African History had become a recognized field of study.

${ }^{42}$ Vansina, Living with Africa, p. 51. For a glowing tribute of Vansina's role see Roland Oliver, In the Realms of Gold: Pioneering in African History, London: Frank Cass, 1997, p. 215. Oliver notes that Vansina's pioneering contribution lay in the collecting of oral testimony not only from the ruling elites but from ordinary clans and families.

${ }^{43} \mathrm{~J}$.W. Blake will be discussed more in Chapter IV, Sources and Historiography. But it is worth noting here that he was a pioneer historian of Africa.

${ }^{44}$ Arthur Percival Newton, 'Africa and Historical Research', Journal of the Royal African Society, Vol. 22, No. 88. July, 1923, pp. 266-277, p. 267; J.D. Fage, On the Nature of African History: an inaugural lecture delivered in the University of Birmingham on the $10^{\text {th }}$ of March 1965, Birmingham, U.K.: University of Birmingham, 1965, p. 3.

${ }^{45}$ Vansina, Living with Africa, p. 57.

${ }^{46}$ J.W. Blake, 'The Study of African History', Transactions of the Royal Historical Society, 4th Ser., Vol. 32, 1950, pp. 49-69.

${ }^{47}$ Oliver, In the Realms of Gold, p. 125.

${ }^{48}$ Vansina, Living with Africa, p. 55. Oliver, In the Realms of Gold, pp. 137-146. 
${ }^{49}$ J.D. Fage, To Africa and Back, Birmingham, U.K.: University of Birmingham, 2002, pp. 8093.

${ }^{50}$ Vansina, Living with Africa, pp. 9, 47-48. Oliver and Fage were considered by Vansina as the prominent pioneers of the discipline.

${ }^{51}$ Both Fage and Oliver make this clear throughout their autobiographies; Fage's To Africa and Back and Oliver's In the Realms of Gold.

${ }^{52}$ Oliver, In the Realms of Gold, p. 142.

${ }^{53}$ Ibid, pp. 145-146.

${ }^{54}$ D.H. Jones, 'II Conference on History and Archaeology in Africa, 16-18 July, 1957', Man, Vol. 57, October, 1957, pp. 151-152. Jones has a discussion on the earlier 1953 conference. See also Roland Oliver, 'African History: SOAS and Beyond' pp. 13-38, specifically pp. 17-18, in Kirk-Greene (ed.), The Emergence of African History at British Universities.

${ }^{55}$ Fage, To Africa and Back, pp. 89-90.

${ }^{56}$ R.A. Hamilton (ed.), with a foreword by C.H. Philips, History and Archaeology in Africa: Report of a Conference held in July 1953 at the School of Oriental \& African Studies, London: School of Oriental and African Studies, University of London, 1955. D.H. Jones (ed.), History and Archaeology in Africa: Second Conference held in July 1957 at the School of Oriental and African Studies, London: School of Oriental and African Studies, University of London, 1959.

${ }^{57}$ Jones, 'II Conference on History and Archaeology in Africa, 16-18 July, 1957', pp. 151-152

${ }^{58}$ Ibid, p. 152. See also Jones (ed.), History and Archaeology in Africa.

${ }^{59}$ Vansina, Living with Africa, p. 54.

${ }^{60}$ Ibid, p. 51; Jan Vansina, 'Ethnohistory in Africa', Ethnohistory, Vol. 9, No. 2, Spring, 1962, pp. 126-136.

${ }^{61}$ Vansina, Living with Africa, p. 51; Fage, To Africa and Back, p. 99.

${ }^{62}$ Oliver, In the Realms of Gold, p. 138.

${ }^{63}$ Ibid, pp. 148-149.

${ }^{64}$ Ibid.

${ }^{65}$ James S. Coleman, 'Research on Africa in European Centers', African Studies Bulletin, Vol. 2, No. 3, August, 1959, pp. 1-33.

${ }^{66}$ Ibid, pp. 1-33.

${ }^{67}$ Ibid.

${ }^{68}$ Author Unknown, 'Historical Theses on African Subjects Completed in Great Britain', African Studies Bulletin, Vol. 4, No. 3, October, 1961, pp. 1-9.

${ }^{69}$ Ibid, p.5. It was not until 1961 that a history thesis was completed that wrote about the history of a West African people within the pre-colonial period ca.1450-1800. The thesis in question was I.G. Wilks, 1959 M.A. thesis: 'Akwamu, 1650-1750: a study of a rise and fall of a West African empire'. Wilks was trained in philosophy, not history, and came to become interested in African history while employed as a philosophy teacher at the University College Gold Coast. His history thesis was examined, not by an historian of Africa, but by an English Tudor historian. What is important about Wilks thesis is that it, unlike many of the other theses completed on Africa, contained research conducted in Africa, including oral sources. There were other theses completed for Africa between 1948 and 1961 which contained oral history, such as that of the African scholars Kenneth Dike and Saburi Biobaku, but unlike Wilks, these authors did not focus on the pre-colonial period. See John Hunwick and Nancy Cawler (eds.), The Cloth of Many Coloured Silks: Papers on History and Society Ghanian and Islamic in Honor of Ivor Wilks, Evanston, Illinous: Northwestern University Press, 1996, p. 9.

${ }^{70}$ See the comments in, Robert W. July, A History of the African People, Prospect Heights, Illinois: Waveland Press, 1992, p. 538; Philip D. Curtin, 'Recent Trends in African Historiography and their Contribution to History in General' in UNESCO General History of Africa, Vol I, New Portsmouth, New Hampshire: Heinemann, 1981, pp. 54-71, and J. F. Ade Ajayi, 'Towards a More Enduring Sense of History', in J.F. Ade Ajayi, History and the Nation and Other Addresses, Ibadan, Nigeria: Spectrum Books Ltd, 1990, pp. 41-43. K. Onwuka Dike, Trade and Politics in the Niger Delta 1830-1885, Oxford, U.K.: Oxford University Press, 1956.

${ }^{71}$ Ajayi, History and the Nation and Other Addresses, p. 41. 
${ }^{72}$ Dike, Trade and Politics in the Niger Delta 1830-1885, p. 224.

${ }^{73}$ Goran Hyden, 'African Studies in the Mid-1990s: Between Afro-Pessimism and AmeroSkepticism', African Studies Review, Vol. 39, No. 2, September, 1996, pp. 1-17, see p. 16, footnote 5. See also the acknowledgement by J.D. Fage, 'Reflections on the Genesis of Anglophone African History after World War II', History in Africa, Vol. 20, 1993, pp. 15-26. Fage comments on p. 19, that 'there can be no doubt whatsoever of Dike's devotion to building up a school of African history when he was in a position of authority at the University of Ibadan. This must have influenced Ajayi, who served under Dike in the Ibadan Department of History and in 1963, after Dike had become Vice-Chancellor, succeeded him in its chair. By about the mid-1950s it was no longer necessary for the African university colleges to send their prospective recruits to African history posts to be supervised overseas by imperial and colonial historians; they could go, for example, to SOAS, as Adu Boahen went in 1956'.

${ }^{74}$ J.D. Fage, 'Obituary: Kenneth Onwuka Dike, 1917-83', Africa: Journal of the International African Institute, Vol. 54, No. 2, 1984, pp. 96-98.

${ }^{75}$ Robert William July, An African Voice: The Role of Humanities in African Independence, Durham, North Carolina: Duke University Press, 1987, p. 143.

${ }^{76}$ A.F.C. Ryder, Benin and the Europeans, 1485-1897. London, Longmans, 1969. See also, Jan Vansina, 'Reviewed work: Benin and the Europeans 1485-1897 by Alan F.C. Ryder', Africa: Journal of the International African Institute, Vol. 40, No. 4, October, 1970, pp. 384-385. Vansina believes that Ryder did not go far enough, ' $[\mathrm{t}]$ he time is now ripe, perhaps, for this author to take the plunge and tie up all that is known about Benin to produce a full history based on the results of all research undertaken in archaeology, anthropology, and history, both oral and written', p. 385.

${ }^{77}$ Roland Oliver (ed.), The Dawn of African History, London: Oxford University Press, 1961, Foreword, p. iii.

${ }^{78}$ Vansina, Living with Africa, p. 56. Vansina stated, '[e]ven in the late fifties, most historians did not actively work with any sources but written ones'.

${ }^{79}$ Ibid, p. 56. See also Oliver (ed.), The Dawn of African History, which was the publication of a series of radio broadcasts aired on the BBC during the summer of 1958 and published in 1961. This publication is a good example of how rather than attempting to master foreign disciplines, historians set about gleaning what they could from other disciplines and integrating it where possible, and for the most part historians published alongside archaeologists, ethnologists, anthropologists and linguists in multidisciplinary volumes. Two similar publications were also produced after a series of BBC broadcasts, in Roland Oliver, (ed.), The Middle Age of African History, London: Oxford University Press, 1967, and John Fage (ed.), Africa Discovers Her Past. London: Oxford University Press, 1970.

${ }^{80}$ Vansina, Living with Africa, p. 51. This is also mentioned in Fage, To Africa and Back, pp. 124-125.

${ }^{81}$ Curtin, 'Third Conference On African History and Archaeology', pp. 10-11.

${ }^{82}$ Christopher Fyfe (ed.), African Studies Since 1945: A Tribute to Basil Davidson, London: Longman, 1976. See T.O. Ranger, 'Towards A Usable African Past', in Christopher Fyfe, (ed.), African Studies Since 1945: A Tribute to Basil Davidson, pp. 17-30. This book is the publication of the conference proceedings. Ranger has taught at universities in Zimbabwe, Tanzania, California, and in the United Kingdom as Professor of Modern History at Manchester University and the Rhodes Chair of Race Relations at the University of Oxford.

${ }^{83}$ Jan Vansina, 'Historians, are Archaeologists your siblings?' History in Africa, 22, 1995, pp. 369-408, see pp. 369-370.

${ }^{84}$ A search of the Journal of African History through the JSTOR online search engine shows twenty four articles published between 1960 and 2002 on radiocarbon dating.

${ }^{85}$ Ranger, 'Towards A Usable African Past', pp. 17-30.

${ }^{86}$ University Grants Committee, Report of the Sub-Committee on Oriental, Slavonic, East European and African Studies, London: H.M.S.O., 1961, pp. 6, 18.

${ }^{87}$ Ibid, p. 40. For a complete analysis of the developments between 1947 and 1960 see Chapter VI, 'Developments outside the Language Departments', pp. 34-40. The Hayter Report 
acknowledged that in 1949 at the University of London an Institute of Commonwealth Studies had been established that focused on the history and social sciences of Commonwealth countries. The London School of Economics had also increased attention on underdeveloped territories such as Africa. The Report noted, p. 35, that at Oxford ten new appointments had been made since 1947 in 'Colonial and Commonwealth history and government, African geography, Anthropology, the economics of underdeveloped countries and tropical agriculture. African studies, in Sociology, Anthropology, History and Politics are well represented in the university, so that Oxford has achieved an international reputation for its work in the African field'. The Report also noted, p. 36, that in 1959-60 there were forty-six postgraduate students working on non-linguistic African subjects, seven of these in History at Oxford. The Report also stated on p. 36 that Cambridge University had increased its interest in Africa but had no research centre focusing exclusively on Africa or Commonwealth affairs.

${ }^{88}$ Ibid, p. 34.

${ }^{89}$ Ibid.

${ }^{90}$ Ibid, p. 41.

${ }^{91}$ Fage, 'British African Studies since the Second World War: A Personal Account', p. 406.

${ }^{92}$ University Grants Committee, Report of the Sub-Committee on Oriental, Slavonic, East European and African Studies, London: H.M.S.O., 1961, Chapter XIII, 'Centres and Area Studies', pp. 80-84; Fage, 'British African Studies since the Second World War: A Personal Account', pp. 397-413.

${ }^{93}$ University Grants Committee, Report of the Sub-Committee on Oriental, Slavonic, East European and African Studies, London: H.M.S.O., 1961, Chapter IX, 'Lessons From America', pp. 53-62. See also p. 123, where the Report notes that the American interest in Africa was only recently stimulated with the contribution of 116 Fellowships for African Studies awarded by the Ford Foundation between 1954-1960. The Report noted that as these people graduate they will likely increase American study of Africa in institutions.

${ }^{94}$ Fage, 'British African Studies since the Second World War: A Personal Account', pp. 397413.

${ }^{95}$ Ibid, p. 408. Antony Allott was lecturer in African law in 1948 and Professor there during 1964-86; he was also the President of the ASAUK during 1969-70.

${ }^{96} \mathrm{Cmd} .2154$, (Higher Education) Report of the Committee appointed by the Prime Minister under the Chairmanship of Lord Robbins, 1961-63, London: H.M.S.O., 1963.

${ }^{97}$ Ibid, pp. 277, 284.

${ }^{98}$ Peter Scott, 'Blueprint or Blue Remembered Hills? The Relevance of the Robbins Report to the Present Reforms of Higher Education', in David Phillips (ed.), Oxford Review of Education, Vol. 14, No. 1, The Legacy of Robbins, 1988, pp. 33-48. See pp. 33, 38. There is an entire volume of the Oxford Review of Education devoted to the Robbin's Report; see David Phillips (ed.), Oxford Review of Education, Vol. 14, No. 1, The Legacy of Robbins, 1988, pp. 1-124.

${ }^{99}$ Cmd. 2154, (Higher Education) Report of the Committee appointed by the Prime Minister under the Chairmanship of Lord Robbins, 1961-63, London: H.M.S.O., 1963, pp. 171-172.

${ }^{100}$ Fage, 'British African Studies since the Second World War: A Personal Account', p. 405

${ }^{101}$ Ibid, pp. 405-406.

102 [Michael Crowder] M.C., 'Roland Oliver', p. 3; [Douglas Rimmer] D.R., 'John Donnelly Fage', p. 194; Oliver, In the Realms of Gold, p. 269. Fage, To Africa and Back, 2002, p. 137. ${ }^{103}$ [Michael Crowder] M.C., 'Roland Oliver', p. 1.

104 [Douglas Rimmer] D.R., 'John Donnelly Fage', pp. 193-201.

${ }^{105}$ Ibid, p. 196.

${ }^{106}$ Fage, To Africa and Back, pp. 180, 218. 


\section{CHAPTER THREE}

\section{AFRICAN HISTORY IN THE UNITED STATES}

African History as part of the academic curriculum in U.S. universities progressed from the developments in the United Kingdom and British African territories after the end of the Second World War. ${ }^{1}$ While U.S. links with Africa, in both a missionary and an educational context, had existed since the end of the nineteenth century, these links did not develop into the creation of African History in the same way that it had in England. ${ }^{2}$ More importantly, the historical links between Africa and the United States were formed through the trans-Atlantic slave trade, which forcibly transported an estimated 305,000 Africans to the United States from the 1620 s to the $1850 \mathrm{~s}^{3}{ }^{3}$ The institution of slavery was so integral to the United States that twelve Presidents were slave owners before slavery's abolition in 1865 . The descendents of these slaves form a major part of the population of the United States and thus the connection between Africa and America is more obvious than that between the United Kingdom and Africa. However, the United States was less direct in transferring the growing awareness for an African perspective in higher education than the British, who controlled substantial African territories between the 1780 s and the 1960s.

Interest in African Studies in the United States had been active since the late nineteenth century, but it remained largely of interest to African-Americans, who, for the most part, were not part of the mainstream academic community. The most notable African-American scholar, W. E. B. Du Bois, published The Negro in 1915, a work that studied ancient African kingdoms in the same manner as early European civilizations. ${ }^{4}$ Thus, Du Bois had foreshadowed the later developments of Africanists in the 1950s and 1960s in acknowledging that Africans had a history that was not inferior to European history. In his 1999 presidential address to the American Historical Association, Africanist scholar Joseph Miller recalled that academic courses in African history were taught by one of Du Bois' former students, the African American scholar Leo Hansberry. Miller noted that Hansberry:

introduced the first academic courses in African history at Howard University in the early $1920 \mathrm{~s}$, [and] capitalized on its nationalist spirit to justify Africans' political accountability. [T] hese pioneering historians of Africa overwhelmed the regional historical traditions of the colonial era and adapted basic progressive assumptions to 
African purposes, demonstrating political centralization and expansion in political scale in Africa of European proportions. ${ }^{5}$

Despite the pioneer efforts of Du Bois and Hansberry, the acceptance of African History as a discipline did not take hold in U.S. universities until after the Second World Warafter the mainstream academic community had 'come on-board'.

In this chapter I chart the development of African History in the mainstream academic community in the United States from 1946 to $1970{ }^{6}$ The rapid shift towards decolonization after the Second World War increased U.S. academic interest in Africa, and by the late 1960s U.S. universities expanded African History courses to be at the forefront of the discipline. The focal point of this chapter is to extend the concept of infrastructure to include the essential role historians played in creating the discipline. I will examine the overall development of African History as an academic subject in the United States, focusing on the acceptance of a strategic national need for and subsequent funding of African Studies programs. I will also look at how African History was expanded through the contribution of individual historians who developed university departments, producing an influential generation of postgraduates. I will focus on the University of Wisconsin as an example of how African History was developed by historians in the United States.

\section{From Area Studies to African Studies, 1946-1970}

African Studies owes its existence in the mainstream U.S. academic community to the importance placed on Area Studies programmes after the Second World War. Between 1946 and 1970 African Studies developed rapidly, illustrating the importance that the study of Africa was given by its financial benefactors. Why were African Studies so important to the United States? The answer lies in the strategic need recognised by the government, private societies and academics for linguistic and cultural understanding between Americans and Africans. This understanding was prompted by the growth of trade between the two regions during the Second World War, the impact of decolonisation that had removed African regions from traditional spheres of European interest, and the urgent security needs perceived by the potential association of these newly created states with the communist Soviet Union.

The background to the funding of Area Studies lies in the acknowledgement by the U.S. Government that higher education was paramount to the interests of the nation. 
In 1946 the U.S. President Harry S. Truman appointed a commission to consider higher education in the United States, and the findings were published in a six-volume report, Higher Education For Democracy, A Report of the President's Commission on Higher Education, in $1947 .^{7}$ According to John Dale Russell, writing in 1949:

The Commission's report stresses the fact that the present is a time of crisis. "In a real sense the future of our civilization depends on the direction education takes, not just in the distant future, but in the days immediately ahead". Three principal goals for higher education are given top priority: "They are to bring to all the people of the Nation: Education for a fuller realization of democracy in every phase of living. Education directly and explicitly for international understanding and cooperation. Education for the application of creative imagination and trained intelligence to the solution of social problems and to the administration of public affairs". These objectives, it will be noted, lie within the general field of the humanities and the social sciences. ${ }^{8}$

The Report emphasised the need for an educated public, recommending that the number of people receiving higher education double from 2 million in 1947/48 to 4.6 million by $1960 .^{9}$ At the time of this report African Studies was virtually non-existent in the mainstream academy, but the need to understand foreign peoples was a stated educational priority.

In May 1949 the Social Science Research Council (SSRC) published Area Studies, with Special Reference to their Implications for Research in the Social Sciences, a report that identified the need for area studies. ${ }^{10}$ The Report highlighted that pre-war Area Studies had focused on Latin American Studies and Far East Studies, but the Second World War had placed urgency on the demand for specialised knowledge about new regions and peoples - those hitherto outside the focus of U.S. scholarly attention. By 1949, the Report authors noted, there had been little interest shown 'in any part of Europe (other than Russia) and there is even less in such major world areas as the Near East, Africa, the Indian World, or Southeast Asia'. ${ }^{11}$ Area Studies was seen as essential to the welfare of U.S. citizens: 'the scholarship of this country was found wanting when put to the test of war-wanting in precise knowledge of different areas and their peoples, and wanting in the accumulation of materials which would have made sound research or analysis possible'. ${ }^{12}$ Furthermore, the Report argued that '[n]ational welfare in the post-war period more than ever before requires a citizenry well informed as to other peoples, and the creation of a vast body of knowledge about them'. ${ }^{13}$ The SSRC Report contended that it was the responsibility of universities, academics, 
libraries and museums to fill gaps in knowledge about areas of the world such as Africa. ${ }^{14}$

The Report also stressed the importance of developing interdisciplinary scholarships for young academics to encourage them to consider particular peoples and cultures from their own perspectives. ${ }^{15}$ The SSRC aimed to promote peaceful relations with foreign nations and so prevent the possibility of a future war. In the event of another war, there would be a body of expert knowledge on regions and peoples. The SSRC Report concluded that centres for Area Studies needed to be supported at universities across the United States and funding given to allow for the expansion of facilities for undergraduate and graduate training. ${ }^{16}$

While funding bodies did not explicitly target African Studies in the late 1940s, the shift towards Area Studies led to a reconsideration of the importance of Africa to the United States in the decade that followed. In 1963 Vernon Mckay published Africa In World Politics, outlining the development of ties between Africa and the United States from the Second World War to the $1960 \mathrm{~s} .{ }^{17}$ Mckay was clearly an influential authority. In 1963 he was Professor of African Studies and the Director of the Programme of African Studies at Johns Hopkins University; Research Associate, Foreign Policy Association; Deputy Director of the Office of Dependent Area Affairs, United States Department of State; Member of the United States Delegations to the United Nations General Assembly, Trusteeship Council and of the Committee on Information from Non-Self Governing Territories; Consultant to the Carnegie Corporation and Ford Foundation; and past President of the African Studies Association. ${ }^{18}$ His career illustrates how a first generation Africanist scholar held numerous positions in governmental and charitable organisations.

McKay believed that the growth in African Studies developed as a consequence of American reliance on African trade during World War Two, the rapid decolonisation of African territories, a rise in humanitarian missions and the fear of Soviet influence. American interaction with African was to serve economic, military and intellectual needs. U.S. financial aid to Africa for the sixteen year period between 1946 and 1961 totalled $\$ 1,800,000,000$ - clearly considerable importance had been placed on American-African relations. To put this figure into perspective, McKay notes that until 1953 American aid to Africa was so small that it does not register in the Government records. Then in 1953 Congress authorised 40 million dollars in financial aid to 
Africa. ${ }^{19}$ Africa, then, had grown in importance each year during the Cold War, and had become central to U.S. interests.

Gwendolen M. Carter, the distinguished historian of Africa and president of the African Studies Association between 1958 and 1959, wrote in 1976 that the creation of African Studies departments in the United States was directly attributable to the provision of funding by private and government organisations. ${ }^{20}$ For Carter, the beginning of African Studies in the United States as we know it today, occurred in 1948 when Northwestern University offered the first African Studies curriculum, which combined courses from several specialities into one coherent programme. $^{21}$ Northwestern University was only able to offer a full programme in African Studies because of funding provided by the privately run Carnegie Corporation in New York. ${ }^{22}$

The creation of Northwestern's African Studies programme in 1948 was followed by rapid expansion of African Studies programmes across the United States over the next decade, all of which were directly attributable to some form of government or private funding. ${ }^{23}$ For example, courses and programmes in African Studies were funded by the Ford Foundation at Boston University and Stanford University in 1953 (although at Stanford studies were primarily in Economic, Agricultural and Food research until 1962/3), Howard University and Harvard University in 1954, and the University of California in 1957. The Ford Foundation also provided funds for research fellowships in African Studies. ${ }^{24}$ Similarly, the Carnegie foundation supported fellowships for the study of Africa, gave funds to Stanford University along with the Ford Foundation, and gave financial support to African Studies at Duke University in $1955 .{ }^{25}$ The Ford Foundation alone gave US\$5 million towards the expansion of African Studies programmes between 1952 and $1960 .{ }^{26}$ In 1957, in keeping with the rapid expansion of African Studies, the African Studies Association (ASA) was founded in New York with Professor Melville J. Herskovits, the director of the African Studies department at Northwestern University, as its first President. $^{27}$ Like the establishment of African Studies in U.S. universities, this association was funded by the Carnegie Corporation and the Ford Foundation. ${ }^{28}$

In 1958 the ASA launched the African Studies Bulletin as a means of keeping its members informed about academic developments. The first issue of the African Studies Bulletin listed the following ten universities offering African Studies programmes: Boston University; University of California at Los Angeles; Duke University (Commonwealth Studies Centre); Duquesne University; Hartford Seminary Foundation; 
Johns Hopkins University (School of Advanced International Studies); Northwestern University; Roosevelt University; Stanford University (Food Research Institute); and Yale University. By 1964 the African Studies Bulletin was able to list twenty-two programmes. $^{29}$

The doubling of African Studies programmes in six years can be in part attributed to the addition of government funding for education, which aimed to combat the fear of Soviet superiority in education. ${ }^{30}$ In 1958 the United States Government passed the National Defence Education Act P.L. $85-864$ (NDEA). ${ }^{31}$ This Act, while concentrating on the urgent need to establish language training centres, also made provision for area studies in general and the commitment to financial support for building African Studies programmes. ${ }^{32}$ The impact of the Act was immediate: it led to the funding and development of African languages and area programmes in African Studies at eight centres by $1965 .{ }^{33}$ Title IV of the Act, 'National Defence Fellowships' aimed to increase the number of college teachers and expand the number of Ph.D. programmes and students through financial assistance to existing and new programmes. Importantly for the field of African Studies, Title IV 'placed no restrictions on the fields of study that could qualify for funding, and it did not require institutional matching funds' ${ }^{34}$ Thus, through a combination of private and government initiatives, African Studies increased significantly. As Philip Curtin noted in 1971, the growth in membership of the African Studies Association increased from about twenty Africanists in 1950 , to about two hundred by 1960 , and then to eighteen hundred by $1970 .^{35}$

Despite the expansion of African Studies from 1948 to 1960, African History remained within African Area Studies departments, and until the 1960s these Area Studies programmes paid little attention to an African perspective. African Studies in the United States consisted mainly of Anthropology and non-historical Social Science departments, which had for some time dominated African Studies. Gwendolen Carter and Philip Curtin noted that in the 1950s African History as a discipline lagged behind African Anthropology, both in numbers of academics and in considering an African perspective. $^{36}$ Developments in the 1960 s proved key. Writing in 1967 Leonard M. Thompson stated that in the 1950s:

American students were encouraged to study African history with grants from the federal government and from foundations. In this respect the Ford-supported Foreign Area Fellowship Program has performed a seminal role. Its first grants for the study of sub-Saharan Africa were made as early as 1954, when the Gold Coast was still 
moving toward independence. In the next four years only seven awards were made to historians, but after that the allocations were increased and by 1966 forty-one Americans and Canadians had been awarded Foreign Area Fellowships for historical study in subSaharan Africa (out of a total of 243 fellowships in all disciplines). ${ }^{37}$

In 1971 Curtin published a disciplinary profile of academics who were members of the African Studies Association in the United States. Curtin noted that the largest increase in numbers of discipline-based scholars between 1960 and 1970 occurred in history, advancing from thirteen to twenty percent (see Table 3 ). ${ }^{38}$ Anthropology, the

Table 3. Discipline Profile of African Studies, 1960-1970.

(1)

Discipline

Anthropology

Political Science

History

Geography

Economics

Sociology

Language, Linguistics, and Literature

Art, Philosophy, Music, and Religion

Psychology

Education

Law

Demography

Other
(2)

$\underline{1960}$

$28.6 \%$

23.0

12.7

10.3

9.4

7.5

2.8

1.4

0.9

0.5

0.5

0.0

100.0
(3)

$\underline{1970}$

$15.5 \%$

21.5

19.6

5.8

8.0

4.6

8.1

2.9

0.9

1.7

0.3

7.6

100.0

Source: Philip D. Curtin, 'African Studies: A Personal Assessment', African Studies Review, Vol. 14, No. 3, Dec. 1971, p. 359.

leading discipline in African Studies in 1960, had been overtaken by History, reflecting the increased personal interest of scholars and increased financial aid the discipline received in this decade. Political Science was particularly strong during the 1960s and 1970s, bolstered by interest in new African nations and by Soviet action in African regions, such as the Congo and Angola. 
In the late 1940s and 1950s Area Studies programs had expanded and acknowledged the need for academic attention towards Africa. In turn this resulted in the establishment of African History as an academic subject in African Studies courses by the end of the 1960s. African Studies developed between 1948 and 1970 as a result of the strategic need perceived by American academics and funding bodies for Area Studies. Now I will concentrate on the development of one African Studies programme, that at the University of Wisconsin, and the pivotal role played by academics in creating an environment to study African History from an African perspective.

\section{Philip Curtin, Jan Vansina and African History at the University of Wisconsin}

As African Studies began to expand in the United States throughout the 1950s and 1960s, the University of Wisconsin made a crucial decision in 1961 to add an African Studies Programme, which remarkably for its time focused on History rather than Anthropology. This programme had come into being largely because of the actions of one its staff members, the historian Philip Curtin. Curtin had joined the Wisconsin faculty in 1956 to replace the British Empire historian Paul Knaplund, and was hired primarily for his expertise in Imperial History and interest in Latin America. ${ }^{39}$ In 1955 Curtin travelled to Africa to research his book The Image of Africa: British Ideas and Action, 1780-1850, published in 1964. This trip began Curtin's lifelong academic relationship with Africa, a relationship that would lead him to create an African History programme at the University of Wisconsin. ${ }^{40}$

Following his trip to Africa, Curtin made several crucial decisions that accelerated the development of the African Studies programme. In 1957 he invited John Fage, then teaching in Ghana, as a visiting Professor to take the Knaplund lectures at Wisconsin. Curtin noted in his autobiography that this decision was made by him in order to 'introduce graduate training in African History' at the university. ${ }^{41}$ Fage taught a British Empire in Africa course for a semester and joined Curtin in his regular seminars, which had by then become seminars in African history. Curtin described Fage's presence at Wisconsin as 'historic', noting that this was 'the first seminar in an American university designed to train doctoral candidates in African history' ${ }^{42}$ Curtin organised the publication of Fage's lectures by the University of Wisconsin Press, a work released in 1959 as Ghana: A Historical Interpretation. ${ }^{43}$ In 1957, Curtin also 
attended the Second African History and Archaeology conference at SOAS in London, hosted by Fage and Oliver. Attendance at this conference introduced Curtin to the work of young Africanists including Jan Vansina. With Curtin's decision to extend his book Image of Africa to two volumes, he regularly travelled from Wisconsin to the United Kingdom, and obtained funding from the Ford Foundation and the University of Wisconsin to return to Africa for research in $1958 / 59{ }^{44}$

Curtin considered moving to one of the three American African Studies centres at the time, Northwestern University, Boston University or the University of California, but Fred Harvey Harrington, vice president at the University of Wisconsin, offered Curtin a chance to develop his own programme. ${ }^{45}$ Under Curtin's leadership the University of Wisconsin developed the Comparative Tropical History programme, which studied Africa, tropical America and South Asia. African Studies, though, was the centrepiece. As Curtin recollected, by 1959/60 the University of Wisconsin 'was becoming known as a place that placed special emphasis on African history'. ${ }^{46}$ Indeed, in 1960 the University of Wisconsin had ten doctoral candidates in African History. ${ }^{47}$ The crowing glory of Curtin's administrative achievement in establishing African History at Wisconsin was the appointment of the young Belgium historian and anthropologist Jan Vansina in 1960, which was followed by the formal creation of a dedicated African Studies programme in $1961 .^{48}$ Roland Oliver noted in his autobiography published in 1997, that during his lecturing visit to the University of Wisconsin in 1962, the programme was 'already a flourishing school of African history that was setting standards of training that were perhaps unique in the world' ${ }^{4}$

Jan Vansina is one of the most well-known and respected historians of Africa. Vansina's reputation rests largely on the fact that he pioneered the use of oral testimonies using methods of both history and anthropology. Prior to completing his doctorate, Vansina had completed his Masters degree in medieval history at the University of Leuven in Belgium and postgraduate training in anthropology at University College, London. ${ }^{50}$ In December 1952 Vansina was posted to Africa as an anthropologist for the Belgium Institute for Research in Central Africa (IRSAC), and between 1953 and 1956 he conducted fieldwork in the Belgium Congo amongst the Kuba people. ${ }^{51}$ During his African research Vansina concluded that oral traditions were legitimate sources for the reconstruction of the past and that his work was in fact historical not anthropological or ethnographical. In 1956 Vansina was accepted as a $\mathrm{Ph} . \mathrm{D}$. candidate by the University of Leuven. The submission of his Ph.D. was 
revolutionary and extremely controversial, only enacted by the University of Leuven in 1957 after considerable debate about its validity as a work of history rather than ethnohistory or anthropology. ${ }^{52}$ Vansina himself later acknowledged the role of his supervisor Jozef-Maria De Smet in supporting him 'because he, a medievalist, had to convince the "establishment" in 1956 that both oral data and the history of a Central African realm were indeed history, and not anthropology, or perhaps folklore. Without him there would not have been a thesis nor a degree in the department of history'. ${ }^{53}$ Vansina focused mainly on oral sources at a time when historians studying Africa relied on written evidence.

The confirmation of Vansina's Ph.D. dissertation, 'The Historical Value of Oral Tradition: Application to Kuba History', enabled Vansina to continue his fieldwork collecting oral testimonies. After the completion of his doctorate Vansina again returned to fieldwork in Africa between 1957 and 1960, finding time in-between research to attend the Second Conference on History and Archaeology in Africa held in July 1957 at SOAS in London. At this conference Vansina contributed to the debate on collecting and using oral sources. ${ }^{54}$ During 1957 and 1958 Vansina hosted both Roland Oliver and Philip Curtin during their research trips to Africa. ${ }^{55}$ Between 1958 and 1960 Vansina continued researching oral traditions for IRSAC and taught some courses at the University of Lovanium in the Belgium Congo, which served both the territories of the Congo and Ruanda-Urundi, until political upheavals forced him to flee Africa and return to Belgium in $1960 .{ }^{56}$ With no fixed employment prospects Curtin convinced Vansina to accept an assistant professorship at the University of Wisconsin in $1960 .{ }^{57}$

While at Wisconsin, Vansina produced the seminal work on oral methodology for historians, Oral Tradition: A Study in Historical Methodology, first published in French in 1961 as De La Tradition Orale: Essai de Méthode Historique. ${ }^{58}$ This work, based partly on his Ph.D. thesis research and fieldwork, sought to provide 'a general discussion on the special nature of oral traditions as a source of information about the past' and 'apply the methods of historical criticism to these sources'. ${ }^{59}$ Vansina claimed that historians can only:

arrive at some approximation to the ultimate historical truth. He does this by using calculations of probability, by interpreting the facts and by evaluating them in an attempt to recreate for himself the circumstances which existed at certain given moments of the past. And here the historian using oral traditions finds himself on exactly the same level as historians using any other kind of historical source material. No doubt he will arrive at a lower degree of probability 
than would otherwise be attained, but that does not rule out the fact that what he is doing is valid, and that it is history. ${ }^{60}$

Oral history was now accepted by Africanists, with Vansina revising his 1965 book in 1985 published as Oral Tradition as History. ${ }^{61}$ A striking feature of Vansina's work, evident throughout his publications, is the critical appraisal of methods and sources, and in particular a keen awareness of the limitations of both.

In 1961, along with the publication of Oral Tradition, Vansina attended the Fourth International African Seminar at the University of Dakar in Senegal. This conference was the first of a series of International African Institute conferences to focus on the emerging role of history as a subject with relevance for Africa, and was attended by many important historians and anthropologists. ${ }^{62}$ The seminar centred on three problems facing the historian of Africa. The first focused on the techniques of the historian: oral tradition, archaeology, ethnography, and linguistics. The second considered the role of the historian in relating the African past to the present. The third explored particular aspects of historical representation within sub-fields such as economics, regions and state systems. ${ }^{63}$ The seminar and subsequent publication of papers focused participants' attention on pre-colonial Africa and on areas where written documentation were scarce. ${ }^{64}$ Importantly, Vansina's participation in this conference and his earlier publications drew academic attention towards the general acceptance of oral sources and Vansina's own expertise. ${ }^{65}$ By 1963 Vansina had been promoted to full Professor at Wisconsin, a year before the publication of this conferences proceedings, and by 1965 headed a separate African History Programme at the University of Wisconsin. ${ }^{66}$

Between 1961 and 1965 Vansina's publishing record was phenomenal. Alongside numerous journal articles he had produced five books by the end of 1964 , four sole-authored and one co-edited. ${ }^{67}$ In 1966 Vansina published his most famous work utilising oral sources to portray African pre-colonial societies, Kingdoms of the Savanna. ${ }^{68}$ Here Vansina was able to convincingly reconstruct aspects of pre-colonial history for regions of Central Africa that had been largely ignored by European historians because of a lack of written sources, and thus strengthened the use of oral traditions as valid tools for historical reconstruction. Kingdoms of the Savanna won the prestigious 1967 African Studies Association Melville J. Herskovits prize for outstanding scholarly work of Africa and firmly established Vansina as one of the most important historians of Africa. ${ }^{69}$ 
After recruiting Vansina to Wisconsin, Curtin set about developing the University of Wisconsin's area studies programmes and his own research agenda. In 1963, to complement the African Studies programme, Curtin instituted the Department of African Languages and Literature, which to this day remains the only one of its kind in the United States. ${ }^{70}$ Thus, the University of Wisconsin had complemented and strengthened the African Studies Programme by expanding the natural links between language study and area study. This was followed by the creation in 1965 of a separate African History Programme under Vansina, with Curtin leading the Comparative Tropical History Programme. Curtin now shifted focus from his 1964 Image of Africa to examine the slave trade. In 1967 he published Africa Remembered: Narratives by West Africans from the Era of the Slave Trade, and in 1969 he produced The Atlantic Slave Trade: $A$ Census. ${ }^{71}$

The Atlantic Slave Trade: A Census attempted a systematic analysis of the scale and geographic distribution of the slave trade. Never before had an academic conducted a comprehensive investigation on the volume of the trade from the mid-1400s to the mid-1800s. According to Eugene D. Genovese, the premier historian of American slavery, Curtin's findings, while focusing primarily on the numbers of enslaved Africans, challenged the existing knowledge and assumptions of the academy. In Genovese's words:

The United States received only five per cent of all Africans in the trans-Atlantic trade; yet in 1950 it contained more than thirty per cent of all those of African descent in the Western Hemisphere. What happens, then, to the common assumption that Southern slavery was so much more rigorous and brutal than Caribbean or South American? Reproduction being a major index of treatment, something is seriously wrong. ${ }^{72}$

While Genovese pondered new questions linking African and American history, Curtin developed his findings in a work on pre-colonial Senegambia.

In 1975 Curtin published Economic Change in Pre-Colonial Africa: Senegambia in the Era of the Slave Trade. John Hargreaves revealed in his review of Curtin's work the connection between The Atlantic Slave Trade and Economic Change in PreColonial Africa:

When Philip Curtin's monumental The Atlantic Slave Trade: A Census... produced new quantitative estimates of the magnitude of the Atlantic slave trade, their importance clearly lay not in some magic in the numbers themselves (for nobody was more careful than Curtin to emphasize that these were liable to substantial margins of 
error), but in the possibilities which they offered for proceeding to real historical accounts of the impact of the growth of this terrible trade upon the economic and social development of African societies. In this major new work Curtin undertakes this task for Senegambia, perhaps that region of West Africa for which we have the best and most varied sources of historical evidence over the last five centuries. ${ }^{73}$

Curtin's work on Senegambia, covering the period 1450-1850, integrated oral sources with archival sources to illustrate that Africa was not isolated or removed from the wider Atlantic world economy. In doing so, Curtin extended his earlier quantitative work on the slave trade to show that Africans themselves were active economic participants rather than passive actors in early modern history.

Curtin's pioneering integration of African history, the slave trade and world history, while obvious today, was not so clear at the time. The revolutionary idea that through studying the slave trade African history could be revealed as part of global history challenged the previously held academic belief of the early twentieth century that Africa was void of history. Curtin demonstrated to the academy that Africans had agency in their own past, and his arguments ultimately reflected his own view that African history was part of a larger global history best seen through a comparative lens, in his case primarily through cross-cultural trade. ${ }^{74}$

Not only did Curtin and Vansina advance African History but they passed their knowledge and enthusiasm on to the next generation of Africanists. Combined, they supervised sixty-two doctoral graduates in the African History programme at the University of Wisconsin. ${ }^{75}$ The contribution of these two men was acknowledged by their colleagues and former students in festschrifts, Africans in Bondage: Studies in Slavery and the Slave Trade: Essays in Honor of Philip D. Curtin on the Occasion of the Twenty-Fifth Anniversary of African Studies at the University of Wisconsin, published in 1986, and Paths Toward the Past: African Historical Essays in Honour of Jan Vansina, published in $19944^{76}$ Both tributes acknowledge the role of Curtin and Vansina in breaking new ground in the approach to African History and in the manner in which each enthusiastically supported the development of graduate students. In Paths Toward the Past the editors, Vansina's past students, note that 'Jan's audacious, inventive spirit has been infectious for his students. Many of us feel that he trusted us to tackle problems that we would never have dared to attempt without his trust... The profession cannot but grow in appreciation of what he has contributed' ${ }^{77}$ 
A clear example of the evidence of Curtin's and Vansina's impact on the discipline can be seen in the Ph.D. graduates produced at the University of Wisconsin. Wisconsin, under Curtin's lead, required that every Ph.D. graduate must conduct fieldwork in Africa and be able to speak and read two foreign languages, one of which must be African. ${ }^{78}$ The result of this requirement, according to Oliver, was that:

the best Wisconsin doctoral graduates were the best trained entrants to the profession from the 1960 s on. Not many were Africans, and not many of the others worked for any considerable time in African Universities, but their collective contribution to research in African history and to the establishment of the subject in the major universities of North America was to be pre-eminent. ${ }^{79}$

The importance placed on African language skills and fieldwork were quite different from SOAS, which never made a mandatory requirement for African fieldwork to be a part of its doctoral programme. ${ }^{80}$

The following table of Ph.D. graduates during the years 1963 to 1996 at Wisconsin clearly illustrates the importance of Curtin and Vansina as supervisors and also illustrates that the majority went on to receive employment as academics (see Table 4). What is also striking about the names included in this list is that many of them are, as Oliver pointed out in 1997, recognised today as the leading scholars of their field. Oliver again emphasised this point in his review of the festschrift for Vansina, noting:

The list of 39 doctoral candidates whom he supervised between 1966 and 1994 contains many of the best-known names in the field today, including Joe Alagoa and Andrew Roberts (1966), Forbes Munro (1968), Allen Isaacman (1970), Joseph Miller (1972), David Henige and Iris Berger (1973), Dennis Cordell (1977), Robert Harms (1978) and David Newbury (1979). ${ }^{81}$

Joseph Miller, like Curtin, had the honour of being elected president of the American Historical Association, which in itself reflected African History's ranking as an academic subject. This Association's importance can be gauged by the fact that its past presidents have included U.S. Presidents Theodore Roosevelt and Woodrow Wilson. Like Vansina, Curtin produced some outstanding scholars-Paul Lovejoy and Patrick Manning to name a select few. Certainly all of the graduates from the University of Wisconsin who went on to pursue academic careers have contributed in turn to the development of the discipline of African History, and all are indebted to the pioneering efforts of Vansina and Curtin. 
Table 4. University of Wisconsin African History Programme Ph.Ds, 1963-1996.

\begin{tabular}{|c|c|c|c|}
\hline YEAR & NAME & ADVISOR & ACADEMIC POSITION \\
\hline 1963 & John William & Curtin & SUNY-Stony Brook (emeritus) \\
\hline 1964 & Julian Witherell & Curtin & Library of Congress (retired) \\
\hline \multirow[t]{3}{*}{1966} & E.J. Alagoa & Vansina & Port Harcourt \\
\hline & Andrew Roberts & Vansina & SOAS (emeritus) \\
\hline & John Rowe & Curtin & Northwestern (emeritus) \\
\hline 1967 & Raymond Kent & Curtin & Berkeley (emeritus) \\
\hline \multirow[t]{2}{*}{1968} & Bruce Fetter & Vansina & Wisconsin-Milwaukee \\
\hline & J. Forbes Munro & Vansina & Glasgow (emeritus) \\
\hline \multirow[t]{7}{*}{1969} & William Brown & Curtin & Wisconsin (deceased) \\
\hline & Victoria Coifman & Vansina & Minnesota \\
\hline & John Davidson & Vansina & Aberystwith (deceased) \\
\hline & R. Hunt Davis & Curtin & Florida (emeritus) \\
\hline & Ross Dunn & Curtin & San Diego State \\
\hline & Patrick Manning & Curtin & Pittsburgh \\
\hline & Leo Spitzer & Curtin & Dartmouth \\
\hline 1970 & Allen Isaacman & Vansina & Minnesota \\
\hline \multirow[t]{4}{*}{1971} & Fred Berg & Curtin & Colgate (emeritus) \\
\hline & Joseph Corry & Curtin & Wisconsin (retired) (admin) \\
\hline & Myron Echenberg & Curtin & McGill (emeritus) \\
\hline & Hassan Mohamed & Vansina & Khartoum \\
\hline \multirow[t]{8}{*}{1972} & Babatunde Agiri & Vansina & Norfork \\
\hline & James Brown & Curtin & South Carolina \\
\hline & M. Jean Hay & Curtin & Boston (emeritus) \\
\hline & Allen Howard & Curtin & Rutgers \\
\hline & Joseph Miller & Vansina & Virginia \\
\hline & Lucy Quimby & Vansina & Psychology \\
\hline & Thomas Tlou & Vansina & Botswana \\
\hline & John Works & Curtin & Missouri (emeritus) \\
\hline \multirow[t]{8}{*}{1973} & Iris Berger & Vansina & SUNY-Albany \\
\hline & Lee Cassanelli & Feierman & Pennsylvania \\
\hline & Jeffrey Fadiman & Vansina & San Jose State \\
\hline & David Henige & Vansina & Wisconsin (library) \\
\hline & James Hubbard & Curtin & \\
\hline & Paul Irwin & Curtin & Stanford (admin) (retired) \\
\hline & Joseph Lauer & Vansina & Michigan State (library) \\
\hline & Paul Lovejoy & Curtin & York (emeritus) \\
\hline \multirow[t]{6}{*}{1974} & Stephen Baier & Curtin & \\
\hline & James Johnson & Curtin & Minnesota (admin) \\
\hline & Claire Robertson & Feierman & Ohio State \\
\hline & Philip Shea & Vansina & Bayero, Nigeria (deceased) \\
\hline & Thomas Spear & Feierman & Wisconsin (emeritus) \\
\hline & Shirin Walji & Feierman & Nairobi \\
\hline \multirow[t]{3}{*}{1975} & Adell Patton & Brown & Missouri \\
\hline & Kings Phiri & Feierman & Malawi \\
\hline & Richard Sigwalt & Vansina & \\
\hline \multirow[t]{2}{*}{1976} & Randall Packard & Feierman & Johns Hopkins \\
\hline & David Sandgren & Feierman & Concordia \\
\hline
\end{tabular}




\begin{tabular}{|c|c|c|c|}
\hline \multirow[t]{2}{*}{1976 (cont.) } & Robert Schecter & Vansina & \\
\hline & Tom Shick & Vansina & Wisconsin (deceased) \\
\hline \multirow{4}{*}{1977} & Henry Bucher & Vansina & Austin \\
\hline & Dennis Cordell & Vansina & Southern Methodist \\
\hline & Peter Koffsky & Feierman & \\
\hline & Monica Schuler & Brown & Wayne State \\
\hline 1978 & Robert Harms & Vansina & Yale \\
\hline \multirow[t]{2}{*}{1979} & John Berntsen & Feierman & State Dept \\
\hline & David Newbury & Vansina & Smith \\
\hline 1980 & Jeffrey Peires & Feierman & \\
\hline \multirow[t]{3}{*}{1981} & Ismail Abdalla & Feierman & William \& Mary \\
\hline & M. Musambachime & Vansina & Zambian Ambassador to UN \\
\hline & Kingsley Ogedengbe & Vansina & \\
\hline \multirow[t]{3}{*}{1982} & Bakonzi Agayo & Vansina & Zaire \\
\hline & Marc Dawson & Feierman & Western New England \\
\hline & Janet Ewald & Brown & Duke \\
\hline 1983 & David Anthony & Feierman & UC-Santa Cruz \\
\hline \multirow[t]{2}{*}{1984} & Carol Dickerman & Feierman & Michigan (admin) \\
\hline & Bryant Shaw & Vansina & USAF \\
\hline 1985 & J.S. Mohlamme & Vansina & VISTA, South Africa \\
\hline \multirow[t]{4}{*}{1986} & Keletso Atkins & Feierman & Minnesota \\
\hline & Elizabeth Eldridge & Vansina & MSU (emeritus) \\
\hline & Susan Grabler & Vansina & Los Angeles CC \\
\hline & James Giblin & Feierman & Iowa \\
\hline \multirow[t]{2}{*}{1987} & Joyce Kirk & Feierman & Wisconsin-Milwaukee \\
\hline & Elizabeth Schmidt & Feierman & Loyola \\
\hline \multirow[t]{3}{*}{1988} & Lynda Day & Feierman & CUNY-Brooklyn \\
\hline & Jonathon Glassman & Feierman & Northwestern \\
\hline & Tharcisse Nsabimana & Vansina & Burundi \\
\hline \multirow[t]{2}{*}{1989} & Kenneth Curtis & Vansina & California State-Long Beach \\
\hline & Renee Tantala & Feierman & \\
\hline 1991 & Michele Wagner & Vansina & Minnesota \\
\hline \multirow[t]{3}{*}{1992} & Nancy Rose Hunt & Vansina & Michigan \\
\hline & Pier Larson & Vansina & Johns Hopkins \\
\hline & Paul Landau & Vansina & Maryland \\
\hline \multirow[t]{2}{*}{1993} & Tefetso Mothibe & Vansina & Lesotho \\
\hline & Joe Lunn & Vansina & Michigan-Flynt \\
\hline \multirow[t]{2}{*}{1994} & Carolyn K Adenaike & Vansina & \\
\hline & Chris Bierworth & Green & Murray State \\
\hline 1995 & David Leaver & Vansina & Georgia Southwestern \\
\hline 1996 & Cathy Skidmore-Hess & Vansina & Georgia Southern \\
\hline
\end{tabular}

Source: University of Wisconsin, African History Programme, http://history.wisc.edu/africa/students/uw_grads.htm, accessed 3 Nov. 2008.

The influence of Vansina and Curtin on their students can be seen by looking at the academic careers of two of their most prominent students, Paul Lovejoy and David Henige. Lovejoy, who completed his Ph.D. under Curtin in 1973, has made a career 
studying Africa, the slave trade and its international dimensions. Henige, who also completed his Ph.D. in 1973, was inspired by Vansina's interest in methodological issues, particularly those pertaining to oral testimony. These two scholars, stimulated by their supervisors, have both been in turn influential in the development of African History. The careers of both of these men are evidence of the importance of their postgraduate training.

Professor Paul E. Lovejoy currently holds the Canada Research Chair in African Diaspora History, and is a Research Professor in the Department of History at York University, Toronto, and the Department of History, University of Hull, Wilberforce Institute for the study of Slavery and Emancipation. He is also a Fellow of the Royal Society of Canada, and the Director of the Harriet Tubman Resource Centre on the African Diaspora at York University. The Canada Research Chairs' Program is part of a national strategy by the government of Canada to make it one of the top countries for research and development. In 2000 the Government created a permanently funded programme to develop research professorships. Lovejoy, as one of the recipients, was appointed Canada Research Chair on the African Diaspora, which had funding totalling \$2.5 million (Canadian dollars) between 1997 and 2002. ${ }^{82}$

One of Lovejoy's most important works, Transformations in Slavery: A History of Slavery in Africa, first published in 1983 and updated in 2000 with information from the W. E. B. Dubois Centre database of slave trade voyages, reflects the inspiration of his mentor Philip Curtin. Martin Klein, also a noted Africanist historian of the slave trade, regards Lovejoy's second edition to still be 'the indispensable summary of the history of slavery within Africa'. ${ }^{83}$ Lovejoy's study examines how slavery developed within indigenous societies and was influenced by international trade, and it is not confined to the trans-Atlantic slave trade but also discusses the impact of slavery on the social, economic, and political development within Africa. ${ }^{84}$ Lovejoy has continued to focus on slaving and the slave trade throughout his career and he is currently investigating the slave trade in the Bight of Biafra, working on a book on the history of slavery in the interior of Nigeria. This work in progress looks at how slavery in the interior relates to the forced migration of enslaved people to the Americas. Along with the publication of five books, fourteen chapters in edited volumes and numerous articles, most of which focus on slavery and the slave trade, Lovejoy has supervised over a dozen Ph.D. dissertations on African history. ${ }^{85}$ Through publications and the 
training of students Lovejoy has continued the work of Curtin in developing African History.

In comparison to Lovejoy, David Henige, a former student of Vansina, contributed to the development of African History through a more structural role. Henige currently works as Bibliographer for African Studies and Anthropology at the University of Wisconsin. According to Henige his decision to study African history was an easy choice given that in the 1960s, 'the field was a tabula rasa, where one could make an impression and also (not insignificantly) get funding, ${ }^{86}$ The choice to apply to the University of Wisconsin was simple: at the time it had 'by far the strongest African history program, with Jan Vansina and Philip D. Curtin, and later others' ${ }^{87} \mathrm{He}$ completed his doctorate in African history from the University of Wisconsin in 1973, after conducting fieldwork in Ghana among the Fante, focusing on the chronology of oral traditions. After a brief stint as a lecturer at the CWAS in the United Kingdom he returned to the University of Wisconsin in 1974, and became the Africana bibliographer for the university, completing a postgraduate Library studies qualification in 1978. Henige was influential in helping to establish the Africana collection at the university into a world class resource for African Studies.

In 1974 Henige founded the journal History in Africa: A Journal of Method. This journal, published annually by the African Studies Association:

focuses on historiographical and methodological concerns and publishes textual analysis and criticism, historiographical essays, bibliographical essays, archival reports and articles on the role of theory and non-historical data in historical investigation. ${ }^{88}$

These topics reflected Henige's academic interest in historical methods. Henige has remained the journal's editor since 1974, and has published several books, primarily of historical methods and criticism and over one hundred and seventy journal articles. ${ }^{89}$ Henige's work was influenced by the critical approach taken by his supervisor in evaluating oral sources and methods. His Ph.D. dissertation, published in 1974 as The Chronology of Oral Tradition: Quest for a Chimera, was considered by Andrew Roberts to be the 'first major theoretical study of oral tradition as historical evidence since Jan Vansina's De la tradition orale (1961)'. ${ }^{90}$ In it Henige discusses the value and limitations of oral traditions in establishing a chronology for societies. His work clearly shows Vansina's influence in oral methodology and in the critical evaluation of the methodology and sources. To this Henige added Oral Historiography (1982), where he 
provided discussion on the historical use of oral sources. In this volume Henige also noted the stimulation and influence of Jan Vansina on his work. ${ }^{91}$

As the editor of History in Africa, head of the Africana collection, and the author of several books, David Henige has for over thirty years been a tireless promoter of African history. Historian Adam Jones, a former student of John Fage, considers Henige to be one of the people who most influenced him after the completion of his doctorate. ${ }^{92}$ Jones, an historian who focuses on pre-colonial Africa, has conducted considerable analysis of early European texts. Henige in his role as editor of History in Africa has promoted the inclusion of numerous articles on the analysis and discussion of written, pre-colonial African sources. Henige's concern for the thorough investigation of evidence illustrates the importance of the limited sources for Africa between 1450 and 1800. The impact of sources, and in particular the few written 'golden texts' of African History, is discussed in the following chapter.

\section{\{}

African History developed as a discipline in the United States from a perceived strategic need to understand Africa and its peoples. Lacking the colonial presence in Africa of the British, Americans nevertheless took to the study of Africa in the post World War Two years with vigour. An infrastructure was funded by both the government and private institutions like the Carnegie Corporation and the Ford Foundation. These organisations identified African Studies as of national importance. The University of Wisconsin took the lead role in developing the rich new field of African History, led by two pioneers, Jan Vansina and Philip Curtin. Under the influence of these two men Wisconsin produced sixty-two doctoral students between 1960 and 1996, half of whom became prominent historians of Africa. Curtin, Vansina and the University of Wisconsin established the academic infrastructure needed to produce ongoing graduates who would help advance the practice of African History. David Henige and Paul Lovejoy are two of these academics to graduate from the African History programme at the University of Wisconsin and are a tribute to the pioneering efforts of Curtin and Vansina. 


\section{Notes to Chapter Three}

${ }^{1}$ Author Unknown, 'African Studies in the United States', African Studies Bulletin, Vol. 5, No. 1, March, 1962, pp. 19-28, see p. 19. It is important to distinguish between African Studies and African History. African History focuses on the history of Africa. African Studies, by contrast is a group of disciplines combined in one department, with history being one component discipline. For example, an African Studies programme like that at Boston University in 1962 offered courses in anthropology and sociology, history, economics, geography and government (politics).

${ }^{2}$ The American involvement in Christian missions to Africa is extremely well documented. For a history of one of the earliest groups to begin missions in Africa, the American Board of Commissioners for Foreign Missions, see Clifton Jackson Phillips Protestant America and the Pagan World: The First Half Century of the American Board of Commissioners for Foreign Missions, 1810-1860, with a foreword by John Fairbank, Cambridge, Massachusetts: East Asian Research Center, Harvard University, 1969.

${ }^{3}$ Voyages: The Trans-Atlantic Slave Trade Database, 'Estimates', http://www.slavevoyages.org/tast/assessment/estimates.faces, last accessed 28 November 2008. ${ }^{4} J$ Joseph C. Miller, 'History and Africa/Africa and History', The American Historical Review, Vol. 104, No. 1, February, 1999, pp. 1-32, see p. 5; W. E. Burghardt Du Bois, The Negro, New York: Henry Holt and Company, 1915.

${ }^{5}$ Miller, 'History and Africa/Africa and History', p. 7. Miller notes the importance of Hansberry in educating future African leaders. Miller writes in footnote 20, p. 7, 'Hansberry's African history derived directly from Du Bois' inspiration and inspired a number of young African students, including Kwame Nkrumah (future president of Ghana) and Nnamdi Azikiwe(nationalist leader in Nigeria)'.

${ }^{6}$ For discussion on African American attention to African history see, Elliott P. Skinner, 'African Studies, 1955-1975: An Afro-American Perspective', A Journal of Opinion, Vol. 6, No. 2/3, Africanist Studies 1955-1975, Summer-Autumn, 1976, pp. 57-67.

${ }^{7}$ Higher Education For Democracy, A Report of the President's Commission on Higher Education, Six Volumes, Washington D.C.: United States Government Printing Office, 1947.

${ }^{8}$ John Dale Russell, 'Basic Conclusions and Recommendations of the President's Commission on Higher Education', Journal of Educational Sociology, Vol. 22, No. 8, Report of the President's Commission on Higher Education, April, 1949, pp. 493-508, see pp. 494-495. ${ }^{9}$ Ibid, p. 496.

${ }^{10}$ Robert B. Hall, Area Studies, with Special Reference to their implications for Research in the Social Sciences, Social Science Research Council Pamphlet 3, New York: Social Science

Research Council, 1949.

${ }^{11}$ Ibid, p. 9.

${ }^{12}$ Ibid, p. 22

${ }^{13}$ Ibid.

${ }^{14}$ Ibid, pp. 22-23.

${ }^{15}$ Ibid, pp. 22-28.

${ }^{16}$ Ibid, pp. 69-87.

${ }^{17}$ Vernon McKay, Africa In World Politics, New York: Harper \& Row, 1963. McKay's book is considered ' $[\mathrm{t}]$ he first 'comprehensive analysis of the nature and significance of Africa's rapidly multiplying contacts with Europe, Asia, and the Americas' (see front cover). By Asia, McKay means the Soviet Union.

${ }^{18}$ Ibid, see dust jacket for a complete listing of McKay's credentials.

${ }^{19}$ Ibid, pp. 364-367. It is interesting to see the breakdown of McKay's figures which show that $\$ 81,500,000$ of this aid was for military assistance.

${ }^{20}$ See the following who also make the claim that African Studies in the United States was created to serve a strategic need; Jacob U. Gordon, 'Teaching the African Experience: A PanAfricanist Approach', African Studies Review, Vol. 19, No. 3, December, 1976, pp. 109-117; Elliott P. Skinner, 'African Studies, 1955-1975: An Afro-American Perspective', p. 59. 
${ }^{21}$ Gwendolen M. Carter, 'African Studies in the United States: 1955-1975', A Journal of Opinion, Vol. 6, No. 2/3, Africanist Studies 1955-1975, Summer-Autumn, 1976, pp. 2-4, see p. 2. Carter acknowledges the pioneering work of Professor Melville J. Herskovits in the 1920s, but notes that African Studies as we know it today developed at a much later stage.

${ }^{22}$ Carnegie Corporation of New York, http://www.carnegie.org/sub/about/mission.html, accessed 14 October 2008, The Carnegie Corporation's website notes that it was set up in 1911, 'to promote "the advancement and diffusion of knowledge and understanding"... [and] 'must benefit the people of the United States, although up to 7.4 percent of the funds may be used for the same purpose in countries that are or have been members of the British Commonwealth, with a current emphasis on Commonwealth Africa'.

${ }^{23}$ Carter, 'African Studies in the United States: 1955-1975', pp. 2-4; Carol A. Dressel, 'The Development of African Studies in the United States', African Studies Bulletin, Vol. 9, No. 3, December, 1966, pp. 66-73. See also listings of university courses in, Author Unknown, 'African Studies in the United States', African Studies Bulletin, Vol. 1, No. 1, April, 1958, pp. 6-20; Author Unknown, 'African Studies in the United States', African Studies Bulletin, Vol. 4, No. 2, May, 1961, pp. 9-20. Other agencies which contributed to the development of Area studies were the Social Science Research Council which administered the Foreign Areas Training Program, the National Research Council and the American Council of Learned Societies. These organisations formed along with the Smithsonian Institute, the pre-war Ethnogeographic Board which promoted Area Studies. After the War, with the termination of the Board, these societies contributed to area studies both individually and through the Committee on World Area Research. See Hall, Social Science Research Council Pamphlet 3, Area Studies, with Special Reference to their implications for Research in the Social Sciences, Preface, p. III. For a discussion on the Ethno-geographic Board and its contribution to Area Studies see Jerome S. Rauch, 'Area Institute Programs and African Studies', The Journal of Negro Education, Vol. 24, No. 4, Autumn, 1955, pp. 409-425.

${ }^{24}$ Dressel, 'The Development of African Studies in the United States', p. 67; Author Unknown, 'African Studies in the United States', African Studies Bulletin, Vol. 1, No. 1, April, 1958, pp. 6-20; Author Unknown, 'African Studies in the United States', African Studies Bulletin, Vol. 4, No. 2, May, 1961, pp. 9-20.

${ }^{25}$ Ibid.

${ }^{26}$ Peter Duignan and L. H. Gann, The United States and Africa: A History, London: Cambridge University Press, 1987, p. 328; Francis X. Sutton and David R. Smock, 'The Ford Foundation and African Studies', A Journal of Opinion, Vol. 6, No. 2/3, Africanist Studies 1955-1975, Summer-Autumn, 1976, pp. 68-72.

${ }^{27}$ It must also be also acknowledged that the Association had been slowly developing since the late 1940s and taking steps for formation as early as 1953. Author Unknown, 'Report of First Annual Meeting - Sept. 8-10, 1958', African Studies Bulletin, Vol. 1, No. 2, November, 1958, pp. 12-21, see p. 13.

${ }^{28}$ Author Unknown, 'History of the African Studies Association', African Studies Bulletin, Vol. 4, No. 2, May, 1961, pp. 32-33, see p. 32; L. Gray Cowan, 'Ten Years of African Studies', African Studies Bulletin, Vol. 12, No. 1, April, 1969, pp. 1-7, see p. 3.

${ }_{29}$ Author Unknown, 'African Studies in the United States', African Studies Bulletin, Vol. 1, No. 1, April, 1958, pp. 6-20; David Brokensha, 'African Studies in the United States', African Studies Bulletin, Vol. 7, No. 1, March, 1964, pp. 12-24.

${ }^{30}$ Pamela Ebert Flattau et al., 'The National Defense Education Act of 1958: Selected Outcomes', Washington D.C.: Institute For Defense Analyses Science \& Technology Policy Institute, 2006. See 'Background and Context for P.L. 85-864, The National Defense Education Act (NDEA)', Section I, p. 1.

${ }^{31}$ Ibid, 'Executive Summary', p. 1, footnote 1, the Public Law (P.L.) number follows the form P.L. 85-864, meaning this law is the 864th law passed by the 85th Congress. The Act can be viewed at, Institute of International Studies, Faculty of Social Sciences, Charles University, 'Documents of American History II, M2010, 1950s: National Defense Education Act of 1958', 
http://tucnak.fsv.cuni.cz/ calda/Documents/1950s/Education_58.html, last accessed 17 October 2008.

${ }^{32}$ Lyman H. Legters, 'The National Defense Education Act and African Studies', African Studies Bulletin, Vol. 7, No. 3, October, 1964, pp. 3-10. Legters worked at the Specialist, Language and Area Centre, U.S. Office of Education.

${ }_{33}^{33}$ Carter, 'African Studies in the United States: 1955-1975', p. 3.

${ }^{34}$ Flattau, et al., 'The National Defense Education Act of 1958: Selected Outcomes', see Section IV, p. 2.

${ }^{35}$ Philip D. Curtin, 'African Studies: A Personal Assessment', African Studies Review, Vol. 14, No. 3, December, 1971, pp. 357-368, p. 358.

${ }^{36}$ Carter, 'African Studies in the United States: 1955-1975', pp. 2-3; Curtin, 'African Studies: A Personal Assessment', pp. 360-361; Philip D. Curtin, On the Fringes of History: A Memoir, Athens Ohio: Ohio University Press, 2005, p. 128.

${ }^{37}$ Thompson, 'African History in the United States', p. 53.

${ }^{38}$ Curtin, 'African Studies: A Personal Assessment', p. 361.

${ }^{39}$ Curtin, On the Fringes of History, p. 93.

${ }^{40}$ Ibid, pp. 71-72. Philip D. Curtin, The Image of Africa: British Ideas and Action, 1780-1850, Madison, Wisconsin: University of Wisconsin Press, 1964. This book represented part one of a two volume publication with the second volume published in 1973.

${ }^{41}$ Curtin, On the Fringes of History, p. 98. Interestingly Fage noted in his autobiography, To Africa and Back, p. 106, that he was chosen only when Dike had become unavailable.

${ }^{42}$ Curtin, On the Fringes of History, p. 129.

${ }^{43}$ Ibid, p. 99; Fage, To Africa and Back, pp. 107-108. See also J.D. Fage, Ghana: A Historical Interpretation, Madison, Wisconsin: University of Wisconsin Press, 1959.

${ }^{44}$ Curtin, On the Fringes of History, p. 99.

${ }^{45}$ Ibid.

${ }^{46}$ Ibid, p. 132.

${ }^{47}$ Ibid, pp. 132-133.

${ }^{48}$ Ibid, pp. 134, 136-137. See also University of Wisconsin, 'African Studies Programme', http://africa.wisc.edu/, last accessed 1 November 2008, which notes start date as 1961.

${ }^{49}$ Oliver, In the Realms of Gold, pp. 262-263.

${ }^{50}$ Vansina, Living With Africa, pp. 6-10.

${ }^{51}$ Ibid, p. 13, Vansina left for the Belgium Congo on the $17^{\text {th }}$ December 1952. Vansina even conducted research while serving in the military for eighteen months from 1954, see p. 34 .

${ }^{52}$ Ibid, pp. 37-39.

${ }^{53}$ Jan Vansina, The Children of Woot: A History of the Kuba Peoples, Madison, Wisconsin: University of Wisconsin Press, 1978, p. ix.

${ }^{54}$ Jones (ed.), History and Archaeology in Africa, pp. 36, 40.

${ }^{55}$ Vansina, Living With Africa, pp. 70-71.

${ }^{56} \mathrm{Ibid}, \mathrm{pp} .60-87$. After independence in 1962 these were known as the countries Rwanda and Burundi.

${ }^{57}$ Ibid, pp. 88-89.

${ }^{58}$ Jan Vansina, Oral Tradition: A Study in Historical Methodology (Trans by H.M. Wright). London: Routledge and Kegan Paul, 1965, originally published in French as, De La Tradition Orale: Essai de Méthode Historique, Tervuren: Musee Royal de l'Afrique Central, 1961.

${ }^{59}$ Ibid, p. 18.

${ }^{60}$ Ibid, p. 186.

${ }^{61}$ Jan Vansina, Oral Tradition as History. Madison, Wisconsin: University of Wisconsin Press, 1985.

${ }^{62}$ J. Vansina, R. Mauny, and L.V. Thomas (eds.), The Historian in Tropical Africa: Studies Presented and Discussed at the Fourth International African Seminar at the University of Dakar, Senegal 1961, London: Oxford University Press, 1964, see pp. 51-53 for a full list. Some of the noted historians in attendance were Roland Oliver, John Fage, Ivor Wilks, Jacob 
Ajayi, Bethwell Ogot, alongside notable anthropologists like Darryl Forde, Jack Goody, and the archaeologist Raymond Mauny.

${ }^{63}$ Ibid, pp. 59-103.

${ }^{64}$ Ibid, p. 59.

${ }^{65}$ Jan Vansina's earlier books are: De La Tradition Orale: Essai de Méthode Historique ,1961; L'evolution du royaume rwanda des origines á 1900, Brussels: Académie Royale des Sciences d'Outre-mer, 1962; Geschiedenis van de Kuba van ongeveer 1500 tot 1904, Tervuren: Musée Royal de l'Afrique centrale, 1963 (Vansina's unaltered published Ph.D. text).

${ }^{66}$ Vansina, Living With Africa, pp. 94, 139. The Comparative Tropical History Programme had been offering African History as a course before this for Masters and Doctoral students. See also p. 140. Vansina did not resign from the Comparative Tropical History Programme until 1968.

${ }^{67}$ Vansina, De La Tradition Orale; Geschiedenis van de Kuba van ongeveer 1500 tot 1904; Le royaume Kuba, Tervuren: Annales du Muśee Royal de l'Afrique Centrale, Sciences Humaines, 1964, and J. Vansina, R. Mauny, and L.V. Thomas (eds.), The Historian in Tropical Africa.

${ }^{68}$ Jan Vansina, Kingdoms of the Savanna, Madison, Wisconsin: University of Wisconsin Press, 1966. See also the later outstanding work of Vansina, The Children of Woot.

${ }^{69}$ African Studies Association, 'Melville J. Herskovits Award Winners', http://www.africanstudies.org/?page=herskovitz_award_winners, last accessed 29 October 2008. Vansina also won this award in 2005 for, How Societies Are Born: Governance in West Central Africa Before 1600, Charlottesville, Virginia: University of Virginia Press, 2004.

${ }^{70}$ Curtin, On the Fringes of History, p. 138. See also, University of Wisconsin, 'African Languages and Literature Department', http://african.lss.wisc.edu/languages/why_page.htm, last accessed 31 October 2008.

${ }^{71}$ Paul E. Lovejoy (ed.), Africans in Bondage: Studies in Slavery and the Slave Trade: Essays in Honor of Philip D. Curtin on the Occasion of the Twenty-fifth Anniversary of African Studies at the University of Wisconsin, Wisconsin, 1986. See p. 1. According to one of his former Ph.D. students, Paul Lovejoy, Curtin, had since his earliest publications in the 1950s, been interested in the history of the slave trade. Curtin, On the Fringes of History, p. 136. Curtin describes it more as a gradual shift from his books, The Image of Africa, 1964 and Africa Remembered: Narratives by West Africans from the Era of the Slave Trade, Madison, Wisconsin: University of Wisconsin Press, 1967. Philip D. Curtin, The Atlantic Slave Trade: A Census, Madison, Wisconsin: University of Wisconsin Press, 1969.

${ }^{72}$ Eugene D. Genovese, 'Reviewed work: The Atlantic Slave Trade: A Census by Philip D. Curtin', The American Historical Review, Vol. 75, No. 7, December, 1970, p. 2011.

${ }^{73}$ J.D. Hargreaves, 'Reviewed work: Economic Change in Pre-Colonial Africa: Senegambia in the Era of the Slave Trade by Philip D. Curtin', The International Journal of African Historical Studies, Vol. 8, No. 4, 1975, pp. 724-726, see p. 724. See also Philip D. Curtin, Economic Change in Pre-Colonial Africa: Senegambia in the Era of the Slave Trade, 2 vols., Madison, Wisconsin: University of Wisconsin Press, 1975.

${ }^{74}$ Curtin, On the Fringes of History, pp. 188-190.

${ }^{75}$ Ibid, p. 175. Curtin's number was smaller because in 1975 he left the University of Wisconsin to go to Johns Hopkins University.

${ }^{76}$ Paul E. Lovejoy (ed.), Africans in Bondage; R. Harms, J. Miller, D. Newbury and M. Wagner (eds.), Paths Toward the Past: African Historical Essays in Honour of Jan Vansina, Atlanta, Georgia: African Studies Association Press, 1994.

${ }^{77}$ R. Harms, J. Miller, D. Newbury and M. Wagner (eds.), Paths Toward the Past, p. 10.

${ }^{78}$ Oliver, In the Realms of Gold, pp. 262-263.

${ }^{79}$ Ibid, p. 263

${ }^{80}$ Vansina, Living With Africa, p. 56.

${ }^{81}$ Roland Oliver, 'Reviewed Work: Paths toward the Past: African Historical Essays in Honor of Jan Vansina, by Robert W. Harms; Joseph C. Miller; David S. Newbury; Michele D. Wagner', The Journal of African History, Vol. 37, No. 1, 1996, pp. 119-120, see p. 119. By 1996 Vansina had supervised forty one Ph.D.s. 
${ }^{82}$ University of Hull, 'Professor David Richardson', http://www.hull.ac.uk/history/Staff/Academic/David_Richardson.html, last accessed 18 November 2008. Richardson worked with Lovejoy on this project and is working on a research project on Slavery and the Slave Trade in West Africa. See also University of Hull, Wilberforce Institute for the study of Slavery and Emancipation, 'Professor Paul E. Lovejoy', http://www.hull.ac.uk/wise/People/Honoraryfellows/Lovejoy/index.html, last accessed 18 November 2008; Government of Canada, Canada Research Chairs, Chairholders, 'Paul E. Lovejoy', http://www.chairs.gc.ca/web/chairholders/viewprofile_e.asp?id=779, last accessed 18 November 2008, which notes Lovejoy as 'a world-leading slave-trade scholar' who '[f]or the past 30 years... has been exploring the dynamics of the African Diaspora'; University of Hull, Wilberforce Institute for the study of Slavery and Emancipation,

http://www.hull.ac.uk/wise/index.html, last accessed 18 November 2008; York University, 'Paul E Lovejoy, Short Curriculum Vitae', http://www.yorku.ca/uhistory/faculty/cv/lovejoy.htm, last accessed 18 November 2008.

${ }^{83}$ Paul Lovejoy, Transformations in Slavery: A History of Slavery in Africa, Cambridge U.K.: Cambridge University Press, 1983, Second edition 2000. Martin A. Klein, 'Reviewed work: Transformations in Slavery: A History of Slavery in Africa by Paul Lovejoy', Canadian Journal of African Studies / Revue Canadienne des Études Africaines, Vol. 36, No. 2, 2002, pp. 390-391, p. 391. See also John K. Thornton, 'Reviewed work: Transformations in Slavery: A History of Slavery in Africa by Paul Lovejoy', The International Journal of African Historical Studies, Vol. 34, No. 1, 2001, pp. 159- 160.

${ }^{84}$ Ralph A. Austen, 'Reviewed work: Transformations in Slavery: A History of Slavery in Africa by Paul E. Lovejoy', The American Historical Review, Vol. 89, No. 3, June, 1984, pp. 820-821.

${ }^{85}$ University of Hull, Wilberforce Institute for the study of Slavery and Emancipation, 'Professor Paul E. Lovejoy',

http://www.hull.ac.uk/wise/People/Honoraryfellows/Lovejoy/index.html, last accessed 18 November 2008; York University, 'Paul E Lovejoy, Short Curriculum Vitae', http://www.yorku.ca/uhistory/faculty/cv/lovejoy.htm, last accessed 18 November 2008.

${ }^{86}$ Email correspondence with David Henige, 27 August 2008.

${ }^{87} \mathrm{Ibid}$.

${ }^{88}$ See JSTOR, The Journal Storage Archive, 'History in Africa', http://fsearchsandbox.jstor.org/journals/03615413.html, last accessed 4 November 2008.

${ }^{89}$ Henige's Ph.D. thesis was published as David Henige, The Chronology of Oral Tradition: Quest for a Chimera, Oxford, U.K.: Clarendon Press, 1974. The latest book of Henige's to investigate methodology is David Henige, Historical Evidence and Argument, Madison, Wisconsin: University of Wisconsin Press, 2005. See the online journal, History Compass, 'David Henige', http://www.blackwell-

compass.com/subject/history/article_biog?article_id=hico_articles_bpl490, last accessed 3 November 2008. Henige was not limited by his training in African History to being confined to histories of the continent and has written works which have added to other subjects. One of the most important of these is In Search of Columbus: The Sources for the First Voyage, Tucson, Arizona: The University of Arizona Press, 1991, in which Henige conducted a textual analysis of sources, focusing on the diario, which was copied from a text written by Bartolomé de las Casas.

${ }^{90}$ A.D. Roberts, 'Reviewed work: The Chronology of Oral Tradition: Quest for a Chimera by David P. Henige', Bulletin of the School of Oriental and African Studies, University of London, Vol. 38, No. 3, 1975, pp. 692-693, see p. 692. Roberts was the editor of the Cambridge History of Africa, Volume 7, 1905 to 1940, Cambridge, U.K.: Cambridge University Press, 1986, and a past graduate of the African History programme at Wisconsin. Roberts had a distinguished career and was for some time Professor of African History at SOAS. As such he is a credible valuator of Henige's work.

${ }^{91}$ David Henige, Oral Historiography, London: Longman, 1982, see Preface [n.p.].

${ }^{92}$ Email correspondence with Adam Jones, 22 August 2008. 


\section{CHAPTER FOUR \\ SOURCES AND HISTORIOGRAPHY: CHARTING THE PRE-COLONIAL AFRICAN PAST, 1450-1800}

In 1949, John Blake addressed the Royal Historical Society on 'The Study of African History'. ${ }^{1}$ Blake, at the cusp of the new era for African History, made two important recommendations for the future direction of academic enquiry in this field. First, scholars were encouraged to study African History from an African point of view. ${ }^{2}$ Second, in order to achieve a new direction for African historical study, a thorough investigation of existing sources and the discovery of new ones was essential to the future development of the discipline. ${ }^{3}$ Importantly, Blake believed that the major written sources for the African past had already been located. Blake acknowledged that although written sources required further analysis, supplementing these with information gained through the disciplines of archaeology, philology and anthropology would greatly expand knowledge of the African past. ${ }^{4}$

When Blake made his speech he was well aware that there was a lack of written material for the first two centuries of European contact with West Africa. ca.1454-1578. In the decade before Blake presented his speech to the Royal Historical Society he had written and published European Beginnings in West Africa 1454-1578. Blake's 1937 work was the published version of his Master of Arts thesis. ${ }^{5}$ European Beginnings in West Africa discussed Iberian rivalry during the first century of Portuguese activity in West Africa. The book was written from European records, primarily those of the Portuguese, and did not include any African sources. Blake followed this early publication with a two-volume work in 1942, Europeans in West Africa 1450-1560: Documents to illustrate the nature and scope of Portuguese enterprise in West Africa, the abortive attempt of Castilians to create an empire there, and the early English voyages to Barbary and Guinea. ${ }^{6}$ Blake and his publisher the Hakluyt Society aimed to present Africa's primary source accounts by the early explorers and travellers to an English reading audience. In volume one Blake published, edited and translated Portuguese and Spanish primary source documents. ${ }^{7}$ Volume two contained the publication of all known source material for the English voyages to Guinea and Barbary. ${ }^{8}$ 
Blake's 1949 call for in-depth analysis of written sources and the integration of African History with other disciplines highlighted the limited source material available for the pre-colonial African past. The intense focus of historians on the classics of precolonial West African history reflects an acknowledgement that some sources for the pre-1800 period are considerably more useful than others. Writing in 1971, John Fage singled out Pieter de De Marees, Pereira, Bosman and Dapper as examples of pivotal European sources for the reconstruction of Africanist pre-colonial history. ${ }^{9}$ This chapter will investigate how sources ca.1450-1800 have contributed to the development of precolonial West African History in the English-speaking world after Blake's 1949 speech by looking at several case studies. I firstly will investigate the contribution of written European sources for pre-colonial history in West Africa and discuss how a selection of these 'golden texts' have influenced the development of the academic discipline of African History. I will then spotlight pre-colonial histories for the port regions of Sierra Leone and New Calabar (Nigeria), ca.1450-1800. We will see how the availability of extant source material has shaped historical studies of these two African Atlantic locations. I will also examine whether or not pre-colonial African History was able to develop along Blake's earlier 1949 recommendations, namely that the discipline of African History would need to integrate the restricted number of written sources with multi-disciplinary evidence in order to present an Africanist view of history.

\section{Golden Texts and the presentation of pre-colonial West African history}

A limited number of written European sources have contributed to the development of the discipline of African History and the Africanist depiction of pre-colonial West Africa between ca.1450 and 1800. Indeed academic African History could not exist without the contribution of 'golden texts', which enable the reconstruction of an Africanist history for pre-colonial African peoples. 'Golden texts' form a crucial element of Africanist history, providing a framework around which oral histories and anthropological research can be better understood. One particular factor of 'golden texts' is that they are time and place specific; there is not a series of written historical sources for any region of West Africa covering that region diachronically throughout the pre-colonial period. The major difference in historical reconstructions of precolonial regions relate to the type and availability of source material. Many regions also share the same written sources, due in part to the limited number of sources available. I 
chose two criteria to define a pre-colonial text as a 'golden text'. First, it must represent one of only a small number of available sources. Second, it must contain valuable historical information.

The academic history of pre-colonial West Africa rests upon a small number of written European sources for the period ca.1450-1800. Scholars, while constantly looking for new written sources within the archives, acknowledge, as Blake pointed out in 1948, that most of the important sources of pre-colonial West Africa are already known to historians. ${ }^{10}$ John Fage, in his compendium of pre-colonial sources, noted that there were 411 published sources in European languages available for West Africa between ca. 1450 to 1800 . Table 5 shows the number of sources broken into fifty- year

Table 5. Original Sources for Pre-colonial Western Africa Published in European Languages, ca.1450-1800.

Years

ca.1450 to 1500

$1501-1550$

$1551-1600$

$1601-1650$

1651-1700

1701-1750

1751-1800

Total

\section{Number of sources}

6

20

48

56

86

66

129

411

Source: J. D. Fage, A Guide to Original Sources for Precolonial Western Africa Published in European Languages: For the Most Part in Book Form, Madison, Wisconsin: University of Wisconsin Press, 1987, second edition 1994, p. ix.

Note: The first entry is amended from 'Sources Prior to the Sixteenth Century', pp. 1-6, to condense the period ca.1450-1500.

periods. It is based on Fage's figures, and does not include shipping and trade accounts, government reports or collections of minor accounts. ${ }^{11}$ The sources sometimes only briefly touch on a particular location, as in the example of Father Barreira, who lived in Sierra Leone from 1606 to 1609. Conversely, some of the sources cover multiple locations. The table makes it clear that there are few written accounts for the period ca.1450-1800 available for the historical reconstruction of pre-colonial West Africa, an 
area of considerable size and diversity. Furthermore it is apparent from the fifty-year breakdown that sources become more prevalent in the second half of the period.

In order to verify the importance of 'golden texts' I conducted a survey of articles published in the Journal of African History. ${ }^{12}$ I catalogued the names of every source listed in John Fage's guide and searched all of the publications of the Journal of African History between 1960 and 2002 inclusive. I then recorded the number of articles that contained references to these sources, limiting my list to those 'golden texts' cited by twenty or more scholarly articles. ${ }^{13}$ The most numerously cited sources are those of Bosman, Dapper and Periera (see Table 6). De Marees, while not listed, is included within the works of Dapper and Barbot, who both reproduced sections of De Marees. ${ }^{14}$ Thus, all of the sources identified by Fage as crucial in 1971 received the most numerous references in the Journal of African History articles up until the end of 2002.

Pereira, Bosman and Dapper (who includes De Marees), are essential sources to reconstruct pre-1700 African history. Duarte Pacheco Pereira was Portuguese and spent his entire life in the service of the crown of Portugal. ${ }^{15}$ He lived between 1450 and 1530, and wrote Esmeraldo de situ Orbis in the years 1505-08. ${ }^{16}$ Pereira's writings were about his own experiences and those of other Portuguese travellers and covered numerous African Atlantic settlements from Morocco to South Africa. ${ }^{17}$ Two of the foremost Africanist historians to write on Pereira, John Fage and Paul Hair, note that the Esmeraldo de situ Orbis is more of a navigational guide, or 'rutter', than a work that sets out to detail the people and places of the African coast. Yet both authors acknowledge that Periera's work contains crucial historical information for the late fifteenth century. ${ }^{18}$ As Hair asserts, the value of Periera's

information on Guinea, other than the purely navigational, is therefore original, hence most valuable, particularly when it deals with the coasts east of Sierra Leone, since these were not reached in the earlier accounts of Zurara, Gomes, Cadamosto, and Fernandes. ${ }^{19}$

For Hair, the Esmeraldo de situ Orbis forms one of a series of pivotal 'golden texts' for the regions of Sierra Leone and the Upper Guinea coast. Fage also considers Periera's material to be a vital text. According to Fage, Pereira's work was the 'first comprehensive account of the Upper Guinea coasts to have survived' and 'the only comprehensive account of the Lower Guinea coast available until that by Pieter de Marees in 1602 ' nearly a century later. ${ }^{20}$ There are fewer sources for Lower Guinea than Upper Guinea until the seventeenth century because fewer Europeans travelled there. ${ }^{21}$ 
Table 6. Published sources before 1801 for pre-colonial West Africa in articles in the Journal of African History between 1960 and 2002 inclusive.

Pre-colonial Source:

CA' DA MOSTO, Alvise da: 1455, first published 1507,

Viagens de Luis de Cadamosto e de Pedro de Sintra, first

English translation abridged 1745, full 1937.

PACHECO PEREIRA, Duarte: 1506, Esmeraldo de situ

Orbis, first published 1892, first English translation 1937.

FERNANDES ALEMÃO, Valentim: 1506, Description de

la Côte Occidentale d'Afrique, first published in two parts, 1856 and 1857, no English translation.

DAPPER, Olfert: Collection first published in 1668,

Naukeurige beschrijvinge der Afrikaenschegewesten van

Egypten, Barbaryen, Lybien, Biledulgerid, Negroslant,

Guinea, Ethiopiën, Abyssinie..., first English translation 1670.

da MONTECUCCOLO, Giovanni Antonio Cavazzi:

1668-1671, Istorica Descrizione de' tre regni Congo,

Matamba ed Angola, first published 1687, no English

translation. John K. Thornton is working on translating the

original manuscripts, which were written in Africa and found in 1969.

BARBOT, Jean (or John): 1678, A Description of the Coasts

of North and South Guinea, published in English 1732

LABAT, Jean-Baptiste: 1685, Nouvelle relation de

L'Afrique Occidentale, first published 1728;

1724/5, Voyage du Chevalier des Marchais en Guinée,

isles voisines et à Cayenne, fait en 1725, 1726 \& 1727, first

published 1730, first English translation 1745.

BOSMAN, William: 1688, Naauwkeurige beschrying van de

Guinese- Goud-, Tand- en Slave-Kust, first published 1704,

first English translation 1705.

DALZEL, Archibald: 1767-1770, The history of Dahomy,

an inland kingdom of Africa, published in English in 1793.

NORRIS, Robert: 1772, A short account of the African

slave trade, published 1788 and was included in Memoirs of

the reign of Bossa Ahádee, King of Dahomy, an inland country of

Guiney, published in English in 1789.
No. of Articles:

23

44

20

25

Sources: J. D. Fage, A Guide to Original Sources for Precolonial Western Africa Published in European Languages: For the Most Part in Book Form, Madison, Wisconsin: University of Wisconsin Press, 1987, second edition 1994; Journal of African History, London: Cambridge University Press, 1960-2002, Vols. 1-43.

Given the fact that there are few sources for Lower Guinea it is no surprise that Periera's information is essential for any historical reconstruction. For example, consider the academic debate on the relationship between Benin and Ife, two pre- 
colonial southern Nigeria cities in the fifteenth and sixteenth century. ${ }^{22}$ The debate centres on the authenticity of local tradition that claims that the ruling dynasty of Benin was related by ancestry to Odudua, the ancestral founder of Ife. ${ }^{23}$ The significance of this concerns the historical makeup and social interaction between African states within the region, and has important consequences for understanding the pre-colonial history of southern Nigeria. Some twenty years after the debate had begun, John K. Thornton explained in his 1988 article 'Traditions, Documents, and the Ife-Benin Relationship' that academic difference of opinion surrounding the history of the region was driven by interpretation of source material. Thornton states that:

the debate about the Ife-Benin relationship has been a standoff that matched information acquired through written documentation against archaeological, traditional and art history evidence, and its resolution would make a contribution to clarifying issues in using each of these sources. $^{24}$

As Thornton suggests, there are considerable multi-disciplinary sources available for the region-artistic, archaeological, written and traditional histories-yet these sources are small in comparison to many other areas of West Africa. Thornton sought to 'reexamine the question primarily from textual evidence, and to propose some new documentary evidence which [could] shed light on the issue'. ${ }^{25}$ The central problem lay in the fact that traditional evidence was adaptive and had changed over time, unlike the early written accounts. Thus, the original documentary evidence contained in Pereira's Esmeraldo de situ Orbis that had started the line of academic enquiry, remained the essential basis from which all other sources could be interpreted. While additional sources were added by Thornton and other academics throughout the ongoing debate, Pereira remained the central starting point for all subsequent historical reconstruction.

Another example of the relevance of Pereira's 'golden text' to the history of Lower Guinea is its contribution to the history of the Yoruba Kingdom of Ijebu in Nigeria. Robin Law, writing in 1986, drew attention to the fact that much of the early historical information on Ijebu that had been repeated in later European documents had derived from the 1614 account of the Portuguese author Manuel de Figuerido, who in turn had taken his information from Pereira. ${ }^{26}$ As a consequence, the seventeenthcentury texts had failed to record the change from ivory to cloth as a primary trade item, a transformation that occurred before the beginning of the seventeenth century. Law pointed out that sixteenth to eighteenth-century writers repeated information derived from Pereira, and hence relied on navigational information from ca.1505-07 at the 
latest. As in the case of the Ife/Benin debate, the lack of extant pre-1800 sources requires historians to cite Pereira's predominantly navigational text in studies on precolonial Ijebu. $^{27}$

Unlike Pereira, Dapper never went to Africa but wrote his work based on travellers' accounts in Africa. Olfert Dapper's text is one of the 'golden texts' for precolonial West African History. Dapper published his work in Amsterdam in 1668, which was translated in 1670 into English by John Ogilby and published as Africa: Being Accurate Description of the Regions of AEgypt, Barbary, Lybia, and Billendulgerid, the Land of Negroes, Guinee, Athiopia, and the Abyssines, with all the Adjacent Islands, either in the Mediterranean, Atlantick, Southern, or Oriental Sea, Belonging Thereunto. ${ }^{28}$ Fage noted 'Dapper's work is the major seventeenth-century synthetic account of Africa'. ${ }^{29}$ Dapper cited most of his sources within the text and many of the published sources are extant, which makes his work of considerable value to historians today. ${ }^{30}$ However, some of Dapper's important sources are lost, such as the unpublished account by the Dutch merchant Samual Blomert. ${ }^{31}$

Adam Jones, another scholar who investigated Dapper's text, also noted that Dapper offered material for Africa that could not be found in any other source. ${ }^{32}$ The first was the 'Kquoja account', which discussed North-Western Liberia and Sierra Leone. The Kquoja account contained extensive historical information on the local peoples, making it a rare document. ${ }^{33}$ The second was the unpublished material Dapper used to write on Loango in what is now Southern Gabon. While containing original information, Dapper's Loango description also included information from other published European accounts. ${ }^{34}$ Jones identified several areas of Dapper's text that could be considered primary material because the sources cited by Dapper are not extant. Robin Law noted that Dapper's account follows on from Perieira's to be one of most important sources for the Ijebu during the seventeenth century. ${ }^{35}$ The value of Dapper's text, like that of Periera's, lies in the fact that it contains information for precolonial Africa that does not exist anywhere else and as such can be considered one of the 'golden texts' for pre-colonial African history.

Whereas Dapper never went to Africa, William Bosman's publication, Naauwkeurige beschrying, published in Utrecht in 1704, was based on first hand experience. Bosman's book is the most cited European text for pre-colonial Africa in the Journal of African History from 1960 to $2002 .{ }^{36}$ Bosman's book became one of the 
most popular travel accounts of the time. ${ }^{37}$ Bosman was sixteen when he first arrived on the Guinea coast in 1688, and by 1698 he had become the Chief Merchant for the Dutch West India Company. ${ }^{38}$ Bosman's long residence on the African Coast and his intimate knowledge of the region has contributed to the value of his work as a primary source. While scholars have noted the bias of some of his opinions, particularly concerning the Komenda Wars between the Dutch West Indies Company and the African Kingdom of Equafo on the Gold Coast (1694-1700), Bosman's work remains an invaluable first hand account of the region. ${ }^{39}$ Bosman's publication, in twenty-two letters, devoted considerable space to describing the peoples and geography of the region. For example, one letter describes the interior states of the Gold Coast, and eight discuss the people, vegetation and animals of the Gold and Slave Coasts. Bosman's work is regionally specific. Bosman also included chapters by the travellers to Africa, David Van Nyendael and John Snoek. Out of the 493 pages of text, 322 pages relate to the Gold Coast, 100 to the Slave Coast, forty-six to the Ivory Coast (written by David Van Nyendael), and twenty-five for the Grain Coast (written by John Snoek). ${ }^{40}$ These sections are extremely valuable to an Africanist historian, making Bosman's text one of the most important 'golden texts' for pre-1800 Africa.

The fact that there remain few 'golden texts' of early modern African history, such as those by Pereira, Dapper and Bosman, has led historians since the 1950s towards a greater focus on textual analysis. The limited number of written pre-colonial sources covering ca.1450-1800 can be seen in John Fage's guide to pre-colonial sources. There are often no oral sources that can be reliably used for the pre-colonial period. Some English historians like Blake acknowledged early in the development of the discipline that the few written sources available needed to be reproduced for academics in order for them to be used to present Africanist history. While the process of translation and editing from an Africanist perspective began in the 1950s and expanded after the launch of the Journal of African History, Adam Jones points out that little early attention was placed on the critical analysis of the texts. ${ }^{41}$ For example, the fourth English translation of William Bosman's account into English in 1967 still contained errors because of its reliance on an earlier incorrect translation. ${ }^{42}$ As can be imagined, the effect of such errors when there were so few sources has had a marked impact on the quality of precolonial West African histories produced. ${ }^{43}$ 


\section{Analysing the historical accuracy of 'Golden Texts'}

Between the 1960s and the end of the 1980s, a gradual acceptance of the importance of analysing what few written sources existed in European languages for pre-colonial West Africa took place in the discipline of African History. The creation of the journal History in Africa: A Journal of Method in 1974, edited by David Henige, responded to the need for a forum to analyse and discuss sources of African history. ${ }^{44}$ Henige stated the journal's agenda in the first volume:

History in Africa proposes to concentrate on these areas of the metier of historical enquiry as they have evolved and as they continue to evolve. This emphasis will be manifested in several related ways. History in Africa will include articles on source criticism and evaluation and the nature of history and historical thought, surveys of the historiography of themes and events, archival and bibliographic reports, review essays of methodological works, and studies of historical problems which are comparative in focus or approach. ${ }^{45}$

For Henige and the editorial advisory board, which included prominent historians such as Vansina, Curtin, Fage, Joseph Miller, Paul Hair, Robin Law, Douglas Jones, the Portuguese Admiral Avelino Teixeira da Mota (whose primary interest was in the investigation of pre-1800 texts), Albert Van Dantzig, Bruce Metzger, Michael Twaddle and Adiele Afigbo (the first doctoral student to graduate from the University of Ibadan), the importance of examining the veracity of sources was a fundamental task of the journal.

From the launch of History in Africa in 1974 academics realised that no new texts would be likely to be discovered for pre-1800 Africa and began to scrutinise the 'golden texts' ${ }^{46}$ Albert Van Dantzig clearly illustrated the need for this work when he published nine articles from 1974 to 1984 in History in Africa, updating the English version of Bosman from the Dutch version. ${ }^{47}$ Dantzig proved that the original 1705 English edition of Bosman was written specifically for an English audience and contained biases for this audience, not to mention numerous translation errors that carried through to the 1967 republication. ${ }^{48}$

In 1978/79 John Fage began work on A Guide to Original Sources for Precolonial Western Africa Published in European Languages: For the Most Part in Book Form, published in 1987. Fage's work comprehensively identified the published primarysource monographs for pre-colonial Africa. The guide was driven by an acknowledgement that historians needed access to a resource that identified all written 
source material for Africa. This book, like the groundbreaking conference held a year before its publication, 'European sources for Sub-Saharan Africa before 1900: Use and Abuse', marked a significant moment in the discipline's development. This conference, the first of its kind to focus on the role and problems of using written European sources for pre-colonial Sub-Saharan Africa, acknowledged that the time had come for African historians to take stock of the discipline, and conduct an investigation into its written source material. $^{49}$

Anthony Kirk-Greene, one of the founding English historians of African History and editor of The Emergence of African History at British Universities, noted that the 1986 conference and subsequent publication made two important points:

[O]ne, that for all the substance in the numerous publications and theses written on the history of Sub-Saharan Africa since 1960 the discussion of sources has received a far lower priority than it deserves; and two, while recognizing that all forms of historical source and methodology must be used in studying the history of Africa, no scholar can afford to ignore the fundamental, often primary, and sometimes pre-eminent role of European-language material in that study. ${ }^{50}$

The conference confirmed the view of earlier scholars like Blake in the late 1940s and Hair in the 1960s, who both realised that the limited amount of source material had to be made available and critically examined. Hair noted at the symposium that '[i]t is precisely because the sources for the Black African past are so limited that the African historian of today has a peculiarly strong obligation to use those sources in the most careful, intelligent and critical way'. ${ }^{51}$ Hair pointed out that majority of contemporary texts for pre-colonial Africa had not been edited. ${ }^{52}$

In 1987 Adam Jones, one of Fage's former students, also published a book which focused on sources, Raw, Medium, Well-Done: A Critical Review of Editorial and Quasi-Editorial Work on Pre-1885 European Sources for Sub-Saharan Africa, 19601986. Jones' book was driven by the findings of the 1986 conference, which established that historians had an urgent need for a guide to the quality and subject matter of academic edited editions of written European sources for pre-colonial Sub-Saharan Africa. This book, along with Fage's, formed essential tools for the historian of precolonial Africa. While not a substitute for critical editions of pre-colonial European texts, the information contained in these two publications enabled historians to begin to locate and evaluate sources for specific histories of Sub-Saharan Africa. 
Since Jones's publication in 1987, the most important editorial work to have been completed on pre-colonial West African history has been Paul Hair, Adam Jones and Robin Law's edited Barbot on Guinea: The Writings of Jean Barbot on West Africa, 1678-1712, published as two volumes in 1992. According to Paul Hair, Barbot's text 'has probably been cited more frequently by twentieth-century writers on precolonial Guinea and on the Atlantic slave trade than any other printed source'. ${ }^{53}$ Barbot's importance as a source was also identified by Fage: 'Jean Barbot was the author of one of three contemporary sources [the other two are Bosman and Dapper] which almost every historian of West Africa between 1650 and about 1750 must take account of (and which most of them quote!)' ${ }^{44}$ Because of Barbot's significance, his work was considered by the editors as 'the starting point for the critical study of many other pre1700 Guinea sources'. ${ }^{55}$ The immense task of editing Barbot's work, which appeared as two versions, one in French and an enlarged English edition, took Hair, Jones and Law twenty years to complete. ${ }^{56}$

The analysis of Barbot by Hair, Jones and Law identified just how important this editorial task was for the sources of pre-colonial West Africa. The editors of Barbot noted that he only spent some sixty days in total on African soil, taking part in two French slaving voyages to Guinea between 1678/79 and 1681/82. ${ }^{57}$ Yet, Barbot is one of the most cited sources for Guinea and the Atlantic slave trade. Hair, Jones and Law examined and identified large sections of Barbot that were derived in some cases wholly and in others partially from other writers. ${ }^{58}$ For example, many of the passages in Barbot were found to be from the work of Olfert Dapper, who in fact cribbed his work from earlier sources, many now lost, and Willem Bosman, who had first hand experience of the Guinea coast. ${ }^{59}$ Nonetheless, much of Barbot's text was original, and through his work written and oral sources survive. The resulting two volumes totalled over 1,000 pages with extensive notation, and has become the definitive scholarly account of Barbot, contributing to the more accurate understanding of African Atlantic history ca. 1700 .

The history of pre-colonial West Africa rests largely on few 'golden texts'. Historians, recognising the importance of 'golden texts', turned their attention to the critical analysis of these texts during the 1970s and 1980s, aided by the creation of the journal History in Africa in 1974. Of the three 'golden texts' listed by Fage, Barbot, and to a lesser extent Bosman, have received critical analysis, but Dapper's Naukeurige 
beschrjvinge has not received the same investigation. ${ }^{60}$ The job of critically annotating these texts can take, as in the case of the Barbot volumes, three scholars twenty years. Nevertheless, historians acknowledge today that any history produced for pre-1800 West Africa is predominantly based on written European sources and must adhere to high standards of scrutiny, a factor not so prevalent during the early development of the discipline in the 1960s.

\section{Source material and the histories of Sierra Leone and New Calabar, 1450-1800}

The early histories of the port community at New Calabar and the port estuary community of Sierra Leone provide an example of how extant source material shapes scholarly writings. Both of these areas were thriving port regions of pre-colonial Africa. By looking at the publications of several prominent scholars I will show how different source material has been used for the two regions in academic publications since Jan Vansina's so-called date of African History's coming of age, 1957. In doing so I will show the relationship between source material and the history produced.

Europeans first landed on the peninsula of Sierra Leone between 1460 and 1461, forty years before reaching New Calabar. Between the arrival of the first Portuguese in 1460 and the founding of the crown colony in 1787, increasing numbers of Europeans visited Sierra Leone. Sierra Leone, only a three-week sail from southwest Europe, attracted Europeans who wanted to purchase gold, camwood, slaves and 'elephants teeth' (ivory). ${ }^{61}$ By value, slaves dominated Sierra Leone's export trade from 1650 to 1808, the year of British slave trade abolition. Data collected for the period 1676 to 1808, the peak years of the slave trade, show that Sierra Leone was the third largest port of embarkation of slaves on the Upper Guinea Coast. ${ }^{62}$ Europeans also anchored off Sierra Leone en route south. Vessels of all sizes could anchor in the large deep water port and re-supply with fresh water and provisions-particularly rice. Even some large British East India ships provisioned at Sierra Leone.

The trading state of the Elem Kalabari, referred to by Europeans as New Calabar, was situated on the River Real in the eastern Niger Delta, in what became known as the Bight of Biafra. The first written record of New Calabar comes from Pachecho Pereira in his Esmeraldo de situ orbis (ca.1505-1508). ${ }^{63}$ Once over the sand bars, the waters at New Calabar and nearby Bonny were 'eleven miles broad, very deep, and navigable by 
ships of any tonnage'. ${ }^{64}$ New Calabar, the village, located some twenty miles from the Atlantic, became an important area of European and African contact in the second half of the seventeenth century. ${ }^{65}$ Though Kalabari merchants first sold mostly ivory, slavetrading became the dominant export business by the 1680s and 1690s. New Calabar was the principal slave trading port of the Bight of Biafra until $1700 .^{66}$ New Calabar's ascendancy in the slave trade dwindled after the mid-eighteenth century when the rival delta states of Bonny and Old Calabar surpassed New Calabar's importance. ${ }^{67}$ Despite its decline, New Calabar remained a port of call throughout the eighteenth and nineteenth centuries as trade gradually shifted from slaves to palm oil. ${ }^{68}$

Visitors to New Calabar, unlike those at Sierra Leone, did not stay for extended periods. There were no European forts or factories at New Calabar to provide residences for travellers. The Kalabari maintained a purely commercial relationship with Europeans, not allowing them to set up permanent bases. When compared with Sierra Leone, New Calabar had a shorter period of concerted European interest, which in turn resulted in fewer European visitors than Sierra Leone. In contrast, many of the explorers, merchants, slavers, naval personnel, colonists and missionaries who stopped at Sierra Leone recorded their experiences, making Sierra Leone one of the most documented regions in West Africa. ${ }^{69}$ The works of Pereira, Dapper and Barbot contain considerably more information of Sierra Leone than they do for New Calabar. In addition to these three accounts, there are many other excellent sources that provide a greater picture of the pre-colonial history of Sierra Leone than those available for New Calabar. In 1507, for example, Valentim Fernandes published an account of the region based in part on the experiences of one of the earliest Europeans to live in Sierra Leone, Alvaro Velho do Barreiro, who had spent eight years there. ${ }^{70}$ No comparable account exists of a European living for any period in New Calabar. Nor is there a comparable account for New Calabar like that of Father Barreira, a Portuguese Jesuit, who lived in Sierra Leone during the early-seventeenth century. Like Alvaro Velho do Barreiro, Father Barreira is today considered as one of the key sources of the region. ${ }^{71}$ Importantly no written account by an African exists for either region before 1800 .

Compared to Sierra Leone, New Calabar also lacks a comprehensive written European record ca.1450-1800. Gwilym Iwan Jones' The Trading States of the Oil Rivers: A Study of Political Development in Eastern Nigeria (1963) contrasts the histories of New Calabar and Bonny. Both in this work and in a later article in 1965, 
Jones notes that only three written works contain relevant written material for pre- 1850 New Calabar. These works are:

the Esmeraldo de Situ Orbis by Pachecho Pereira, which refers to the end of the fifteenth and beginning of the sixteenth century; the Description of Africa by Olfert Dapper, which refers to the middle of the seventeenth century; and the Description of the Coasts of North and South Guinea by John Barbot, printed in the eighteenth century, but referring to the end of the seventeenth. ${ }^{72}$

Importantly, these three traders' descriptions, or commercial handbooks, do not give historians comprehensive histories of the eastern Bight of Biafra. Jones also points out that the 'native traditions', learned through oral evidence, only become valid as a source after the beginning of the eighteenth century, when recollected history can be corroborated with information in the accounts of Captain John Adams and Captain Hugh Crow from the 1790s. ${ }^{73}$ Even recently discovered information on the trade with New Calabar by the Dutch, who were prominent traders during the mid-seventeenth century, does not add much to Pereira, Dapper, and Barbot. ${ }^{74}$ Though New Calabar was an important trading port between 1650 and 1800, it is surprising that few written accounts for this period survive. Out of the 411 pre-1800 sources listed by Fage, only three written sources for pre-colonial New Calabar are the basis for most of its academic history. $^{75}$

The lack of written source material for New Calabar has shaped how scholars approached its study. With an abundance of written material Sierra Leone's pre-colonial history could be largely reconstructed from written European sources. The minimal written accounts for New Calabar, however, resulted in a reliance on oral evidence. ${ }^{76}$ As a consequence, all of the published histories of pre-colonial New Calabar have not been produced by historians but by anthropologists. G. I. Jones completed a history degree, but became actively involved in field research among the people of the eastern Niger Delta during colonial service in Nigeria. Upon his return to England, Jones became a lecturer in the Department of Social Anthropology at Cambridge University. In 1962 he became a Fellow of Jesus College, retiring in $1971 .^{77}$ Robin Horton, who has lived in Africa since the 1960s, trained in philosophy and anthropology and was Professor of Anthropology at the University of Ife, Nigeria, and Professor of Philosophy and Religious Studies at the University of Port Harcourt, Nigeria. ${ }^{78}$ Neither Jones nor Horton were trained African historians. Instead the pair worked as anthropologists, conducting fieldwork and collecting oral evidence to supplement scattered information 
from the minimal written material. While oral history was accepted by the first generation of African Historians as a viable source there was also an acknowledgement of its limitations. As G. I. Jones noted in 1963: 'Neither class [oral or written sources] is capable of standing by itself; they have to be taken together and used to correct, check, and amplify each other'. ${ }^{79}$ The problem of using oral history for the pre-colonial period was clearly summarised by Pair Hair when reflecting on thirty years of the discipline from 1964 to 1994. Hair stated that:

oral traditions...have an inbuilt "horizon" of recollection which falls far short of the arrival of the Europeans five centuries ago. Ethnographic, cultural, and linguistic evidence, systematized in recent times, can be extrapolated backwards to earlier times, but this can only be done, with any security, when trends over time have been identified from earlier hard evidence. ${ }^{80}$

Thus oral history is a problematic source for the pre-colonial period, ensuring that written European sources remain vital forms of evidence for pre-colonial West Africa.

The availability of sources has resulted in striking differences in the number of publications on pre-colonial New Calabar and Sierra Leone. The single most obvious point of difference is that there is no single book dedicated to the history of New Calabar. In contrast, Sierra Leone has over twelve single volume histories, the most important of which are Peter Kup's A History of Sierra Leone, 1400-1787 (1961), 212 pages, and Christopher Fyfe's A History of Sierra Leone (1962), 773 pages. ${ }^{81}$ Sierra Leone also has two single volume bibliographies, one online web-bibliography and two article length bibliographies, which include primary and secondary sources for its history. ${ }^{82}$ The region has also been the subject of six different academic journals. ${ }^{83}$ Indeed, Sierra Leone is one of the most comprehensively studied regions of West Africa.

By contrast, there are just two prominent historical works that cover the history of New Calabar during the pre-colonial period, G. I. Jones', The Trading States of the Oil Rivers, and Robin Horton's, 'From Fishing Village to City-State: A Social History of New Calabar' (1969), in Mary Douglas and Phyllis M. Kaberry (eds.), Man in Africa: Essays in Honour of the Late Professor Daryll Forde. ${ }^{84}$ Both works rely on oral testimony, as the only informative written account for New Calabar during the seventeenth century is Barbot. Jones and Horton, in fact, tell readers that their works contain many speculative conclusions. ${ }^{85}$ Horton, the most published English scholar on New Calabar, directed the majority of his academic career to studying the religious and 
philosophical aspects of the Kalabari people, writing anthropological rather than historical works. ${ }^{86}$ He believes that Jones' history of New Calabar, though published in 1963, 'cannot be substantially improved upon'. ${ }^{87}$ To date, some forty years after they were written, the works by Jones and Horton remain the standard references for precolonial New Calabar.

The written sources for Sierra Leone are so rich that it sustained the academic careers of three English historians, Christopher Fyfe, Peter Kup and Paul Hair. ${ }^{88}$ Quantitatively, Fyfe, Kup and Hair have published the most written work on Sierra Leone. All three historians published works on Sierra Leone during Ranger's so called 'golden period' of African History between 1960 and 1980. In the 1960s both Fyfe and Kup published single volume histories of Sierra Leone, Kup's History of Sierra Leone 1400- 1787 (1961) and Fyfe's History of Sierra Leone (1962). ${ }^{89}$ In contrast, Paul Hair, who wrote on Sierra Leone from the early 1950s until his death in 2002, did not publish a single volume history of Sierra Leone. Hair, however, is considered the most published historian on Sierra Leone having an extensive article list, several chapters in edited publications and an edited collection of his out of print writings. ${ }^{90}$

Like Jones and Horton who wrote on New Calabar, Fyfe, Kup and Hair were not trained Africanist historians before they began working on Sierra Leone. All three had spent time working in Sierra Leone. Christopher Fyfe was a school teacher in Germany before becoming a Government archivist in Sierra Leone from 1950 to 1962. Fyfe had a history degree but never applied for or completed a Ph.D., nor did he ever teach African history at an African University. Nonetheless, he became lecturer in African history at the University of Edinburgh in the newly founded Centre of African Studies in 1962 and Reader in $1964 .{ }^{91}$ Peter Kup held the Chair of History at the University of Sierra Leone between 1963 and 1965 having completed his Ph.D. in Tudor history. ${ }^{92}$ Paul Hair graduated with a history degree from Cambridge in 1949 and a Ph.D. from Oxford in 1955 on 'The Social History of British Coalminers 1800-1845'. Between 1952 and 1965 he worked at Ibadan University in Nigeria, the University of Sierra Leone and as Senior Lecturer in History at the University of Khartoum in the Sudan. In 1965, Hair became a lecturer in African history in the History Department at the University of Liverpool, and from 1979 until his retirement in 1990, he held a Chair in Modern History. ${ }^{93}$

Christopher Fyfe, Peter Kup and Paul Hair deployed varying sources to present their histories of pre-colonial Sierra Leone. Fyfe's History of Sierra Leone predominantly studies the colony of Sierra Leone, 1787-1909. ${ }^{94}$ The fact that there are 
no other comparable single volume histories for any other sub-Saharan region reveals both the importance of Sierra Leone and the large number of sources available. Despite clearly knowing the most important source material for Sierra Leone from the fifteenth century to the twentieth century, Fyfe choose to write his encyclopaedic work on the history of the colony from the late-eighteenth century to the beginning of the twentieth century. ${ }^{95}$ Fyfe limited his study to the period he knew best. As government archivist, he was familiar with colonial documents, and was best placed to write a comprehensive history of the colony. Furthermore, when Fyfe began his project, oral history was very much in its infancy. Fyfe did not conduct any oral research, although he cited other scholars' work on African oral traditions and linguistics. ${ }^{96}$ Importantly, Fyfe demonstrates that in the last half of the eighteenth century the written material on Sierra Leone had increased dramatically, particularly after colonisation in $1787 .^{97}$ Though a colony-focused study, Fyfe's work included considerable information on the local African peoples described by frequent European visitors. To date Fyfe's History of Sierra Leone remains an authoritative text.

Peter Kup's History of Sierra Leone (1961), covering the period 1400-1787, should along with Fyfe's publication, provide the reader with a comprehensive history of Sierra Leone, ca.1400-1909. Unlike Fyfe's publication, Africanist scholars received Kup's book poorly, citing his misuse of sources. ${ }^{98}$ Kup relied on the already well known written European sources for the region and provided a good basic history of Europeans on the coast. However, he did not add any new sources of information to his history, and he failed to integrate accurately written evidence with that from archaeological or oral testimonies. ${ }^{99}$ When he attempted to incorporate seventeenth-century oral testimony to reconstruct the mid-sixteenth century Mani invasion of Sierra Leone, for instance, he was criticised by Douglas Jones, a noted historian of Ghana and a proponent of oral history. Jones wrote: 'Dr. Kup does not seem to have used any work of his own on oral tradition and does not appear best at handling this kind of material', and he criticised one attempt as 'insubstantial fancy'. ${ }^{100}$ Another critical reviewer, Paul Hair, commented that one of Kup's sources, Father Balthasar Berriera, had not been correct in his assertion of the Mani invasion. ${ }^{101}$ In a separate review, Christopher Fyfe highlighted the major failing in Kup's study: Kup failed to adequately engage with the advances in African History that had been made in the field during the 1950s. ${ }^{102}$ Despite the misgivings voiced by these Africanist scholars, Kup's book demonstrates that during 
the 1960s there were sufficient sources to attempt a single volume history of Sierra Leone for the period 1400-1787.

Paul Hair is the most influential historian to have written about pre-colonial Sierra Leone. Hair published articles on the Sierra Leone region from the mid-1950s through to 2002. ${ }^{103}$ Compared to Peter Kup and Christopher Fyfe, Paul Hair's publications are the most Africanist. Like Kup and Fyfe, Hair did not actively seek out and pursue the use of oral traditions. This is a major difference between the published history of Sierra Leone and New Calabar. Hair, while having undertaken field research in Africa alongside anthropologists, linguists and Africans, decided that there were sufficient pre1700 European written materials covering Sierra Leone and the neighbouring coasts of Western Guinea to occupy his research career in African History. ${ }^{104}$ Hair worked extensively translating and editing European documents concerning West Africa. ${ }^{105}$ For example, he studied the linguistic references contained throughout European documents diachronically over the Guinea coast region in an attempt to chart the course of precolonial migration patterns. ${ }^{106}$ In doing so he reconstructed one of the most thorough ethno-linguistic pictures available for pre-colonial West African peoples. Hair's work has been evaluated by specialists in the field, and is still considered essential historical information today, a fact borne out by the publication of Hair's collected articles in 1997. ${ }^{107}$ Paul Hair's work is a testament to the value of written European evidence to the reconstruction of African pre-colonial history and has greatly expanded the academic understanding of Sierra Leone's pre-colonial past.

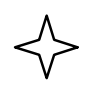

In the presentation of pre-1800 histories of New Calabar and Sierra Leone written after the acceptance of African History as an academic discipline, source material directly contributed to the amount and quality of these studies. To write the pre-1800 history of New Calabar, scholars relied on oral histories and acknowledged the limitations of myths, legends and stories. The reliance on oral testimonies contributed to the history of New Calabar being written by anthropologists and not by professional historians. Where significant written accounts were available, little oral source material was used as seen in the history of Sierra Leone. As a consequence, Sierra Leone had a more detailed history published that has sustained the academic careers of three historians. Despite methodological advances in oral history and the importance of archaeology, a handful of 'golden texts' represent the most important sources for pre-1800 West African 
history. One of the most important developments of the discipline is the way sources have shaped both the presentation of histories and the careers of academics. Particular to the development of the discipline, Africanists learned to demonstrate the limitations in all pre-colonial sources, written or oral. 


\section{Notes to Chapter Four}

${ }^{1}$ Blake, 'The Study of African History', pp. 49-69. John W. Blake, M.A., RF.Hist.S, Hon.D.Litt. (Keele), Hon. D. Litt., was the vice chancellor of the University of Botswana, Lesotho and Swaziland, 1964-1971. See National University of Lesotho, 'Historical Note', http://www.nul.ls/about/history.htm, last accessed 19 August 2007. P.E.H. Hair, 'J.W. Blake: A Tribute', History in Africa, Vol. 16, 1989, pp. 413-414. See p. 413. Paul Hair, a noted African Historian, paid tribute to the loss of Blake in 1987, acknowledging Blake's speech as a groundbreaking moment in the development of African History. For Hair, Blake had presented the revolutionary idea of an African History from an African point of view to 'that most traditional and Eurocentric (almost insular) of historical clubs, the austere Royal Historical Society of London', and in doing so lent his standing as a prominent scholar to the call for African History to be presented as a stand alone discipline removed from the shadow of Imperial History. This event occurred in 1949, one year after John Fage dated the beginning of the modern discipline of African History.

${ }^{2}$ Blake, 'The Study of African History', p. 49.

${ }^{3}$ Ibid, pp. 57, 58, 64.

${ }^{4}$ Ibid, p. 64.

${ }^{5}$ Blake began work on this book in 1933 as part of his M.A. thesis, 'International Rivalry in West Africa (1454-1559), completed at the University of London in 1936 and published as the book, European Beginnings in West Africa 1454-1578, London: Longmans Green, 1937.

${ }^{6}$ Blake, Europeans in West Africa 1450-1560: Documents to illustrate the nature and scope of Portuguese enterprise in West Africa, the abortive attempt of Castilians to create an empire there, and the early English voyages to Barbary and Guinea, Volume I and II, London: Hakluyt Society, 1942.

${ }^{7}$ Blake, Europeans in West Africa 1450-1560, Vol. I.

${ }^{8}$ Blake, Europeans in West Africa 1450-1560, Vol. II, p. 249.

${ }^{9}$ Fage, 'Continuity and Change in the Writing of West African History', see pp. 238-239. Fage states, 'because of their antiquity, such of these early descriptions of West Africa and its peoples as survived in an available form have become historical sources of the first rank, which from the 1950s onwards became essential reading for teachers and students of West African history...it might be noted that the historical value of works like these had long been known, but that the growth of academic study and teaching of African history from the 1950s onwards involved using them in a new way, not, as hitherto, as sources for European or Muslim activities in Africa, but as sources for the history of the African peoples themselves'.

${ }^{10}$ There are new sources which crop up from time to time, but they do not alter the outline of what is already known. A recent new source is, Adam Jones (trans. and ed.), West Africa in the Mid-Seventeenth Century: An Anonymous Dutch Manuscript, Atlanta, Georgia: African Studies Association Press, 1995.

${ }^{11}$ J.D. Fage, A Guide to Original Sources for Precolonial Western Africa Published in European Languages: For the Most Part in Book Form, Wisconsin, 1987, second edition 1994, p. ix, first entry amended from Fage's original table by using his 'Sources Prior to the Sixteenth Century', pp. 1-6, to condense date ca.1450-1500. This does not include shipping and trade accounts, government reports, or collections of minor accounts, see p. viii.

${ }^{12}$ I investigated the Journal of African History due to a comment by Fage in 1971 that most of the important work had not been published in books but articles. See Fage, 'Continuity and Change in the Writing of West African History', see pp. 249-250.

${ }^{13}$ I limited my search to 'golden texts' written by Europeans which relate to West Africa and have been published in English. I also choose not to include the records of the numerous European African companies, or the records of the African Association. Mungo Park is often cited in the Journal of African History, but I do not consider his work at the turn of the eighteenth century a 'golden text' and have not included it.

${ }^{14}$ De Marees has eighteen article references in the Journal of African History between 19602002. Without further investigation it is hard to tell how much of Dapper and Barbot's citations 
actually referred to De Marees work. It is, however, a fair bet that there would be enough to include him in the top list although I have not done this. For a comment on the use of De Marees by Dapper and Barbot see: Richard Rathbone, 'Review: Albert van Dantzig; Adam Jones (Translators and editors), Description and Historical Account of the Gold Kingdom of Guinea (1602), by Pieter de Marees', Bulletin of the School of Oriental and African Studies, University of London, Vol. 52, No. 2, 1989, p. 406. Rathbone states, 'Pieter de Marees's very early account of West Africa, and especially the Gold Coast, has oddly been largely ignored by scholars in favour of later works by better known writers like Bosman, Dapper or Barbot. Dapper and Barbot - and other authorities shamelessly plagiarized de Marees, and his under-use by scholars is hard to explain. The original text was re-published by Linschoten-Vereeniging in 1912 and edited with remarkable scholarly diligence by S.P. l'Honore Naber. Naber argued that de Marees had been overlooked because of the subsequent popularity of William Bosman's Nauwkeurige beschryving van de Guinese Goud-, Tand en Slav-kust (Utrecht, 1704). Bosman has been available to scholars not merely in Dutch but also in English, French, German and Italian and, as Naber argued in 1912, much of his appeal was due to his availability to scholars who could not or would not read Dutch. Van Dantzig and Jones are to be warmly congratulated for opening up the extremely important riches in de Marees's account to a wider public and for doing so in such a scholarly fashion'.

${ }^{15}$ J.D. Fage, 'A Commentary on Duarte Pacheco Pereira's Account of the Lower Guinea Coastlands in His "Esmeraldo de Situ Orbis", and on Some Other Early Accounts', History in Africa, Vol. 7, 1980, pp. 47-80, see p. 48.

${ }^{16}$ Ibid, p. 49. Fage writes, 'Pacheco Pereira's original manuscript is not extant; all modern editions of the Esmeraldo derive from two copies, one in the Biblioteca Nacional in Lisbon, which is known to have been made in the later eighteenth century, and one in the Evora library, which is older (though how much is uncertain), and which may have been the source for the Lisbon copy'.

${ }^{17}$ P.E.H. Hair, 'The Early Sources on Guinea', History in Africa, Vol. 21, 1994, pp. 87-126, see p. 97.

${ }^{18}$ Fage, 'A Commentary on Duarte Pacheco Pereira's Account of the Lower Guinea Coastlands in His "Esmeraldo de Situ Orbis", and on Some Other Early Accounts', pp. 47-80; Hair, 'The Early Sources on Guinea', pp. 97-98.

${ }^{19}$ Hair, 'The Early Sources on Guinea', pp. 97-98.

${ }^{20}$ Fage, 'A Commentary on Duarte Pacheco Pereira's Account of the Lower Guinea Coastlands in His "Esmeraldo de Situ Orbis", and on Some Other Early Accounts', pp. 47-48. Fage does note that Pereira's work can be 'supplemented by references to narratives of European voyages to Lower Guinea that were made within about fifty years of Pacheco Pereira's composition, most notably that by Eustache de la Fosse in 1479/80 - perhaps the earliest surviving direct account of a visit to Lower Guinea - and the English voyages of the 1550s.

${ }^{21}$ Fage, 'A Commentary on Duarte Pacheco Pereira's Account of the Lower Guinea Coastlands in His "Esmeraldo de Situ Orbis", and on Some Other Early Accounts', p. 47. Fage noted '[t]he exploration of the 900 or so miles of the Guinea coast to about as far as Cape Mesurado was a more deliberate process, over some eighteen years, than was that of the nearly 2000 miles of coast between Cape Mesurado and Cameroun, which seems to have-been undertaken essentially in the five years, $1471 / 1475$ '.

${ }^{22}$ For discussion on this see John K. Thornton, 'Traditions, Documents, and the Ife-Benin Relationship', History in Africa, Vol. 15, 1988, pp. 351-362. Thornton writes on p. 352, '[s]ince Ryder's article a number of scholars have taken up the debate, looking over the evidence and for the most part failing to come up with either decisive support for Ryder's position or a convincing demonstration against it. Additional archaeological work and further work by art historians, while it has undermined some of Ryder's evidence (particularly his contention that Ife was not an ancient city or that its art was not crucial to artistic development in the region) have nevertheless failed to provide conclusive new evidence to eliminate Ryder's position or to propose unchallengeable support for it'. For discussion on the Ife Benin relationship see also, A.F.C. Ryder, 'A Reconsideration of the Ife-Benin Relationship', The Journal of African 
History, Vol. 6, No. 1, 1965, pp. 25-37; Ryder, Benin and the Europeans; Fage, 'A

Commentary on Duarte Pacheco Pereira's Account of the Lower Guinea Coastlands in His

"Esmeraldo de Situ Orbis", and on Some Other Early Accounts', pp. 47-80.

${ }^{23}$ Ryder, 'A Reconsideration of the Ife-Benin Relationship', p. 25.

${ }^{24}$ Thornton 'Traditions, Documents, and the Ife-Benin Relationship', pp. 351-362, see p. 352.

${ }^{25}$ Ibid.

${ }^{26}$ Robin Law, 'Early European Sources Relating to the Kingdom of Ijebu (1500-1700): A

Critical', History in Africa, Vol. 13, 1986, pp. 245-260, see p. 252.

${ }^{27}$ Ibid. See also footnote 58, p. 260, where Law noted that the earliest most substantial account for Ijebu was that 'of an Ijebu slave sold out of Africa in 1820'.

${ }^{28}$ Olfert Dapper, Naukeurige beschrijvinge der Afrikaenschegewesten van Egypten, Barbaryen, Lybien, Biledulgerid, Negroslant, Guinea, Ethiopie "n, Abyssinie... Getrokken uyt verscheyde hedendaegse lantbeschrijvers en geschriften van bereisde ondersoekers dier landen, Amsterdam, 1688; Olfert Dapper, (translated by John Ogilby), Africa: Being Accurate Description of the Regions of Agypt, Barbary, Lybia, and Billendulgerid, the Land of Negroes, Guinee, Athiopia, and the Abyssines, with all the Adjacent Islands, either in the Mediterranean, Atlantick, Southern, or Oriental Sea, Belonging Thereunto, London: Thomas Johnson, 1670.

${ }^{29}$ Fage, A Guide to Original Sources for Precolonial Western Africa Published in European Languages, p. 46, entry on Dapper.

${ }^{30}$ J.D. Fage, 'Slaves and Society in Western Africa, c.1445-c.1700', The Journal of African History, Vol. 21, No. 3, 1980, pp. 289-310, see pp. 291-292.

${ }^{31}$ Fage, A Guide to Original Sources for Precolonial Western Africa Published in European Languages, p. 46, entry on Dapper. Fage notes that this might be the source of the famous description of 'Kquoja and their neighbours in the Sierra Leone - Cape Mount region and for some parts of his information on Benin and the Congo'.

${ }^{32}$ Adam Jones, 'Decompiling Dapper: A Preliminary Search for Evidence', History in Africa, Vol. 17, 1990, pp. 171-209, see p. 181.

${ }^{33}$ Jones, 'Decompiling Dapper: A Preliminary Search for Evidence', p. 181.

${ }^{34}$ Ibid. See also p. 186 where Jones made the point that while his survey was brief, that '[o]ne thing is clear: until we have firmer evidence than we do at present, it is unwise to attach phrases such as "in about 1666," "by the 1660s" or even "by the mid-seventeenth century" to historical statements based upon this material.[By this material he is referring to the Kquoja and Loango accounts.] It is quite possible that some of the unpublished sources dated from the 1620 s or even earlier'.

${ }^{35}$ Law, 'Early European Sources Relating to the Kingdom of Ijebu (1500-1700): A Critical', History in Africa, pp. 245-260. Law mentions Castello Branco's report of 1620 and Olfert Dapper's account of the 1660s. Law on p. 253 states that '[a]fter Dapper's account in the 1660s, there seem to be no further sources alluding to Ijebu based on original information for over a century'.

${ }^{36}$ The first English translation, A New and Accurate Description of the Coast of Guinea, was published in London, in 1705.

${ }^{37}$ Albert van Dantzig and Willem Bosman, 'Willem Bosman's "New and Accurate Description of the Coast of Guinea”: How Accurate Is It?', History in Africa, Vol. 1, 1974, pp. 101-108. See p. 105.

${ }^{38}$ Ibid, p. 102.

${ }^{39}$ For an extremely recent discussion on this see Robin Law, 'The Komenda Wars, 1694-1700: A Revised Narrative', History in Africa; 2007, Vol. 34, pp. 133-168. While Bosman's bias is clear from the evidence of the new source his view only opens up a better understanding of how events were perceived from each side.

${ }^{40}$ William Bosman, with an introduction by J.R. Willis, and notes and appendix by J.D. Fage and R.E. Bradbury, A New and Accurate Description of the Coast of Guinea: Divided into the Gold, the Slave, and the Ivory Coasts, (1704), Fourth English edition, London: Frank Cass, 1967. See the comments by Wills p. xix, introduction. 
${ }^{41}$ See Adam Jones, Raw, Medium, Well-Done: A Critical Review of Editorial and QuasiEditorial Work on Pre-1885 European Sources for Sub-Saharan Africa, 1960-1986, Madison, Wisconsin: University of Wisconsin Press, 1987, pp. 3-4, for a description of the beginning of the textual analysis process. John Blake was one of the important British scholars to undertake this work.

${ }^{42}$ This work, according to Albert Van Dantzig, has numerous translation errors. See Dantzig and Bosman, 'Willem Bosman's "New and Accurate Description of the Coast of Guinea": How Accurate Is It?', pp. 101-108.

${ }^{43}$ See David Henige, 'The Race is not Always to the Swift', in Beatrix Heintze and Adam Jones (eds.), 'European sources for Sub- Saharan Africa before 1900: Use and Abuse', Paideuma 33, Stuttgart, 1987, pp. 53-79. Henige notes Bosman's English translation as an example of distorted history, p. 56.

${ }^{44}$ David Henige, 'On Method: An Apologia and a Plea', History in Africa, Vol. 1, 1974, pp. 17. See also Jones, Raw, Medium, Well-Done, p. 6.

${ }^{45}$ Henige, 'On Method: An Apologia and a Plea', p. 1.

${ }^{46} \mathrm{See}$ in addition to Dantzig the following list of journal articles that look at sources, most of these date from the 1980s onwards: W. Lawrence, 'Some Source Books for West African History', The Journal of African History, Vol. 2, No. 2, 1961, pp. 227-234; Hair, 'Barbot, Dapper, Davity: A Critique of Sources on Sierra Leone and Cape Mount', pp. 25-54; P.E.H. Hair, 'Some Minor Sources for Guinea, 1519-1559: Enciso and Alfonce Fonteneau', History in Africa, Vol. 3, 1976, pp. 19-46; Fage, 'A Commentary on Duarte Pacheco Pereira's Account of the Lower Guinea Coastlands in His "Esmeralo de Situ Orbis", and on Some Other Early Accounts', pp. 47-80; Adam Jones, 'Double Dutch? A Survey of Seventeenth-Century German Sources for West African History', History in Africa, Vol. 9, 1982, pp. 141-153; Robin Law, 'Jean Barbot as a Source for the Slave Coast of West Africa', History in Africa, Vol. 9, 1982, pp. 155-173; Adam Jones, 'Semper Aliquid Veteris: Printed Sources for the History of the Ivory and Gold Coasts, 1500-1750', The Journal of African History, Vol. 27, No. 2, Special Issue in Honour of J.D. Fage, 1986, pp. 215-235; Law, 'Early European Sources Relating to the Kingdom of Ijebu (1500-1700): A Critical Survey', pp. 245-260; Thornton, 'Traditions, Documents, and the Ife-Benin Relationship', pp. 351-362; Jones, 'Decompiling Dapper: A Preliminary Search for Evidence', pp. 171-209, Hair, 'The Early Sources on Guinea', pp. 87126; P.E.H. Hair, 'The History of the Baga in early Written Sources', History in Africa, Vol. 24, 1997, pp. 381-391. See also the following books; Heintze and Jones (eds.), 'European sources for Sub- Saharan Africa before 1900: Use and Abuse'; Fage, A Guide to Original Sources for Precolonial Western Africa Published in European Languages; Jones, Raw, Medium, WellDone; P.E.H. Hair, Adam Jones, and Robin Law, (eds.), Barbot on Guinea: The Writings of Jean Barbot on West Africa, 1678-1712, 2 vols., London: Hakluyt Society, 1992; Adam Jones (ed.), Olfert Dapper's Description of Benin (1688), Madison, Wisconsin: University of Wisconsin Press, 1998.

${ }^{47}$ Dantzig and Bosman, 'Willem Bosman's "New and Accurate Description of the Coast of Guinea”: How Accurate Is It?', pp. 101-108; Albert van Dantzig, 'English Bosman and Dutch Bosman: A Comparison of Texts', History in Africa, Vol. 2, 1975, pp. 185-216; 'English Bosman and Dutch Bosman: A Comparison of Texts, II', History in Africa, Vol. 3, 1976, pp. 91-126; 'English Bosman and Dutch Bosman: A Comparison of Texts: III', History in Africa, Vol. 4, 1977, pp. 247-273; 'English Bosman and Dutch Bosman: A Comparison of Texts: IV', History in Africa, Vol. 5, 1978, pp. 225-256; 'English Bosman and Dutch Bosman: A Comparison of Texts: V', History in Africa, Vol. 6, 1979, pp. 265-285; 'English Bosman and Dutch Bosman. A Comparison of Texts: VI', History in Africa, Vol. 7, 1980, pp. 281-291; 'English Bosman and Dutch Bosman: A Comparison of Texts: VII', History in Africa, Vol. 9, 1982, pp. 285-302; 'English Bosman and Dutch Bosman: A Comparison of Texts: VIII', History in Africa, Vol. 11, 1984, pp. 307-329.

${ }^{48}$ Bosman's work was originally published in Dutch four times, 1704, 1709, 1719 and 1737, French 1705, English 1705, 1721, 1907, and 1967, German 1706, Italian 1752-54. 
${ }^{49}$ Heintze and Jones (eds.), 'European sources for Sub- Saharan Africa before 1900: Use and Abuse', p. 1. The conference was conceived by Jones and Heintze in 1983. See also Jones, Raw, Medium, Well-Done, p. 7.

${ }^{50}$ A.H.M. Kirk-Greene, 'Reviewed work: European Sources for Sub-Saharan Africa before 1900: Use and Abuse by Beatrix Heintze; Adam Jones', Bulletin of the School of Oriental and African Studies, University of London, Vol. 51, No. 3, 1988, pp. 614-615; Heintze and Jones (eds.), 'European sources for Sub- Saharan Africa before 1900: Use and Abuse', pp. 1-17. ${ }^{51}$ See the article of the presentation by Paul Hair, 'The Editing of Early European-Language Texts on Black Africa', in Heintze and Jones (eds.), 'European sources for Sub- Saharan Africa before 1900: Use and Abuse' pp. 29-51.

${ }^{52}$ Hair, 'The Editing of Early European-Language Texts on Black Africa', p. 33.

${ }^{53}$ P.E.H. Hair, 'On Editing Barbot', History in Africa, Vol. 20, 1993, pp. 53-59. See footnote 7 , p. 59.

${ }^{54}$ J.D. Fage, 'Review: 'Good Red Herring': The Definitive Barbot', The Journal of African History, Vol. 34, No. 2, 1993, pp. 315-320, see p. 316.

${ }_{55}^{55}$ Hair, 'On Editing Barbot', p. 53.

${ }^{56}$ Ibid, p. 54.

${ }^{57}$ Hair, Jones, and Law (eds.), Barbot on Guinea, vol. 1, p. xlii.

${ }^{58}$ Ibid, p. xx. The editors removed only the totally derived passages, showing where the omission was and detailed where partially derived material originated along with analysing the original material.

${ }^{59}$ There are other sources mentioned by the editors throughout the notes and detailed in the introduction of volume 1. Hair, Jones, and Law (eds.), Barbot on Guinea. It is worth noting the comments of Jones, 'Semper Aliquid Veteris: Printed Sources for the History of the Ivory and Gold Coasts, 1500-1750', pp. 215-23. Jones pointed out that the textual plagiarism conducted by most European writers before the end of the nineteenth century was not seen with disdain as it is today. With so few sources it was seen as appropriate for these to be recycled and updated with fresh evidence.

${ }^{60}$ Jones (ed.), Olfert Dapper's Description of Benin (1688). In the preface Jones states his work is 'the first step in what I hope will one day be a complete edition of the original material in Dapper's description of Africa'.

${ }^{61}$ Fyfe, A History of Sierra Leone, pp. 1-12; Hair, Jones, and Law, (eds.), Barbot on Guinea, vol. 1 , pp. ix-xiii.

${ }^{62}$ David Eltis, Paul E. Lovejoy and David Richardson, 'Slave Trading Ports: Towards an Atlantic-Wide Perspective, 1676-1832', in Robin Law and Silke Strickrodt (eds.), Ports of the Slave Trade (Bights of Benin and Biafra), Papers from a Conference of the Centre of Commonwealth Studies, University of Stirling June 1988, Stirling, U.K.: Centre of Commonwealth Studies, University of Stirling, 1999, pp. 12-34, see pp. 18-19.

${ }^{63}$ R. Mauny (ed.), Duarte Pacheco Pereira, Esmeraldo de situ orbis (Côte occidentale d' Afrique) (1507), Bissau, 1956. For an earlier translation see Kimble (ed.), Duarte Pacheco Pereira, Esmeraldo de Situ Orbis (1507), London, 1937. See also Fage, 'A Commentary on Duarte Pacheco Pereira's Account of the Lower Guinea Coastlands in His "Esmeraldo de Situ Orbis", and on Some Other Early Accounts', pp. 47-80.

${ }^{64}$ James MacQueen, A Geographical Survey of Africa, Its Rivers, Lakes, Mountains, Productions, States, Population, \&c. With a Map on an Entirely New Construction To Which is Prefixed a Letter to Lord John Russell Regarding the Slave Trade and the Improvement of Africa, London: B. Fellowes, 1840, Facsimile reprint of first edition, London: Cass, 1969, p. 136.

${ }^{65}$ Ibid.

${ }^{66}$ Eltis, Lovejoy and Richardson, 'Slave Trading Ports: Towards an Atlantic-Wide Perspective, 1676-1832', p. 21.

${ }^{67}$ Ibid.

${ }^{68}$ This shift to palm oil was championed by Old Calabar. 
${ }^{69}$ There is a correlation between the number of European visitors, the length of their stay, and the number of recorded sources. For example, Donald R. Wright notes that Lower Gambia had the most visitors for pre-colonial Africa and as such was a rich tradition of written sources. Donald R. Wright, 'Requiem for the Use of Oral Tradition to Reconstruct the Precolonial History of the Lower Gambia' History in Africa, Vol. 18, 1991, pp. 399-408, see p. 400. Wright notes that, 'Niumi [Situated on the river Gambia] had longer continuing contact with various European mariners and merchants, from about 1440, than about any other state in black Africa'. Like Niumi, Sierra Leone, due to its frequent European visitation has large number of sources.

${ }^{70}$ Hair, Afro European Contacts in Guinea, pp. 10-11. For a list of editions of Valentim Fernandes see Fage, A Guide to Original Sources for Precolonial Western Africa Published in European Languages, p. 8.

${ }^{71}$ Father Barreira worked in Sierra Leone from 1606 to 1609. His work has been published in the volumes of Fernao Guerreiro, Relaçam anual das cousas que fizeram os Padres da Companhia de Jesus nas partes da Padres daIndi Oriental en emalguas outras...Tirado tudo das Cartas dos mesmos Padres....Lisbon: Pedro Crasbeeck, 1603-11, reprinted by A. Viegas three volumes, Coimbra: Imp. da Universidade, 1930-42. See also the contemporary translation in French by Pierre du Jarric, Histoire des choses les plus mémorables tant ez Indes Orientales, que autres pais de la descouverte des Portugais...et principalement de ce que les Religieux de la Compagnie de Jésus y ont faict.... Bordeaux: S. Millanges, 1608-14. See also the important work by A. Brasio, Monumenta Missionaria Africana, Africa Ocidental, 2nd ser., 4, Lisbon: Agência Geral do Ultramar: Academia Portuguesa de História, 1968, which is a collection of Portuguese documents. Paul Hair has translated some of Barreira's work into English, for a list see P.E.H. Hair, 'Jesuit Documents on the Guinea of Cape Verde and the Cape Verde Islands, 1585-1617 in English Translation', History in Africa, Vol. 16, 1989, pp. 375-381. See a list of various translations and editions available in P.E.H. Hair, 'A Bibliographic Guide to Sierra Leone 1450-1650’, Sierra Leone Studies, No. 10, 1958, pp. 62-72.

${ }^{72}$ G.I. Jones, 'Time and Oral Tradition with Special Reference to Eastern Nigeria', The Journal of African History, Vol. 6, No. 2, 1965, pp. 153-160, see p. 156; G.I. Jones, The Trading States of the Oil Rivers: A Study of Political Development in Eastern Nigeria, London: Oxford University Press, 1963, pp. 1-3. On p. 3 Jones notes the existence of some other written documentation and refers to J.W. Blake's work but notes that these are minor documents. ${ }^{73}$ Jones, The Trading States of the Oil Rivers, pp. 32-33, 43. See Captain Hugh Crow, Memoirs of the Late Capt. Hugh Crow, London: Longman, Rees, Orme, Brown, and Green, 1830, reprint Frank Cass \& Co. Ltd., 1970; Captain John Adams, Sketches taken during ten voyages to Africa between the years 1786 and 1800, London: Hurst \& Robinson, 1822; Remarks on the country extending from Cape Palmas to the river Congo, London: G. \& W.B. Whittaker, 1823.

${ }^{74}$ Adam Jones (trans. and ed.), West Africa in the Mid-Seventeenth Century, An Anonymous Dutch Manuscript, Atlanta, Georgia: African Studies Association Press, 1995. See pp. 6-7 for a discussion on New Calabar information contained in the manuscript.

${ }^{75}$ In comparison, Fage lists forty seven sources for the rivers of Guinea and Sierra Leone. Fage, A Guide to Original Sources for Precolonial Western Africa Published in European Languages, p. 191. This figure is derived from Fage's 'Geographical Guide to Entries'. Interestingly there are twenty entries for the Bight of Biafra of which New Calabar is a part, but only three of these relate to New Calabar.

${ }^{76}$ The descriptions of who the oral evidence was obtained from is rather poor in Jones and Horton's works. The assumption was that the sources were well documented in the authors own field notes.

${ }^{77}$ Simon Ottenberg, 'In Memoriam: G. I. Jones, 1904-1995' African Arts, Vol. 28, No. 3, Summer, 1995, pp. 21-21.

${ }^{78}$ Professor Ruth Finnegan, provided some biographical details on Horton by email on 30 May 2008. Finnegan wrote, 'I'm a little vague now on the details but know that Robin Horton did an undergraduate degree in what was known as 'PPP' (Philosophy, Psychology and [I think] Physiology - it was the first two which specially interested him) at the University of Oxford sometime in the 1950s, then anthropology at UCL (University College London)-I'm not sure 
what his official connection was there, i.e. whether he did formal courses and a post-graduate degree etc but know he did spend some time there, and always had a particular rapport with Mary Douglas. He did fieldwork among the Kalabari in Nigeria, and spent most of his subsequent life at one or other Nigerian University from sometime in the 1960s (he was certainly at the University of either Ibadan or Ife (in Ibadan) in early 1965 and had already at that point been there some time)'.

${ }^{79}$ G.I. Jones 'European and African Tradition on the Rio Real', The Journal of African History, Vol. 4, No. 3, 1963, pp. 391-402, see p. 391.

${ }^{80}$ Hair, 'The Early Sources on Guinea', p. 87.

${ }^{81}$ A.P.[ Peter] Kup, A History of Sierra Leone, 1400-1787, Cambridge U.K.: Cambridge University Press, 1961; and Fyfe, A History of Sierra Leone. These are not the only single volume histories of Sierra Leone. See A.B.C. (Aaron Belisarius Cosimo) Sibthorpe, The History of Sierra Leone, with an introduction by Robert W. July, 1868, fourth edition, London: Frank Cass, 1970, pp. 228; Christopher Fyfe, 'A. B. C. Sibthorpe: A Tribute', History in Africa, Vol. 19, 1992, pp. 327-352, who notes that Sibthorpe was most likely born in Sierra Leone; John Joseph Crooks (the former colonial secretary of Sierra Leone), A History of the Colony of Sierra Leone, Dublin: Browne and Nolan 1903, reprint, London: Cass, 1972; Christopher Fyfe, A Short History of Sierra Leone, London: Longman, 1962; Christopher Fyfe, Sierra Leone Inheritance, London: Oxford University Press 1964; C. Magbaily Fyle, The History of Sierra Leone: A Concise Introduction, London: Evans Brothers, 1981; A.P. Kup, Sierra Leone: A Concise History, New York: St. Martin, 1975; John Eric Peterson, Province of Freedom: A History of Sierra Leone, 1787-1870, London, Faber and Faber, 1969; Richard West, Back to Africa: A History of Sierra Leone and Liberia, New York: Holt, Rinehart and Winston, 1970.

${ }^{82}$ See also the lists in the following bibliographies; Sir Harry Charles Joseph Luke, $A$ Bibliography of Sierra Leone; Preceded by an Essay on the Origin, Character, and Peoples of the Colony and Protectorate, Oxford U.K.: Clarendon press, 1910, reprint London: Oxford University Press, 1925, reprint of 1925 edition, New York: Negro Universities Press 1969; Geoffrey J. Williams, A Bibliography of Sierra Leone, 1925-1967, New York: Africana Publishing Corp., 1971; Sierra Leone Web, online bibliography, http://www.sierraleone.org/bibliography.html, last accessed 1 October 2007; Hair, 'A Bibliographic Guide to Sierra Leone 1450-1650', pp. 62-72; P.E.H. Hair, 'A Bibliographic Guide to Sierra Leone 16501800’, Sierra Leone Studies, No. 13, 1960, pp. 41-49.

${ }^{83}$ Adam Jones, 'Reviewed work: Journal of the Historical Society of Sierra Leone, Vol. I, Nos. 1-2, (1977)', The International Journal of African Historical Studies, Vol. 15, No. 4, 1982, pp. 754-756.

${ }^{84}$ Gwilym Iwan Jones, The Trading States of the Oil Rivers: A Study of Political Development in Eastern Nigeria, London: Oxford University Press, 1963, Robin Horton, 'From Fishing Village to City-State: A Social History of New Calabar', pp. 37-58 in Mary Douglas and Phyllis M. Kaberry (eds.), Man in Africa: Essays in Honour of the Late Professor Daryll Forde, London: Tavistock, 1969. New Calabar is not completely void of history. For example most of the works by Robin Horton throughout his extensive career focus on New Calabar, but these tend to be more anthropological rather than historical and focus on case studies particularly that of Kalabari religion. There are quite a few works which include New Calabar but these do not give any comprehensive history of the region and most of these do not give a history of the region before ca.1800. A good case in point is the work of Dike, Trade and Politics in the Niger Delta, 1830-1885. Dike mentions New Calabar in the pre-colonial period but only briefly and not as a full history and quickly moves on to his intended focus of trade between 1830-1885. This book is the closest to a dedicated book on New Calabar but it is very specific and not a general history but a social anthropological study. For a discussion on religious practices see Robin Horton, The Gods as Guests: An Aspect of Kalabari Religious Life, Third in the series of special Nigeria Magazine publications, Lagos: Nigeria Magazine, 1960. See also David Northrup, Trade Without Rulers: Pre-Colonial Economic Development in South-Eastern Nigeria, Oxford, U.K.: Clarendon Press, 1978. Northrup's book contains a reasonable amount of information on New Calabar, but does not introduce any new historical information than 
offered by Jones and Horton. Northrup uses them as sources and also relies on the same sources primary sources for New Calabar.

${ }^{85}$ Robin Horton, 'From Fishing Village to City-State: A Social History of New Calabar', p. 39. See also Jones, The Trading States of the Oil Rivers, p.1.

${ }^{86}$ An example of this is, Robin Horton, 'The Kalabari World-View: An Outline and Interpretation', Journal of the International African Institute, Vol. 32, No. 3, July, 1962, pp. 197-220. See also the collection of selected works by Robin Horton, Patterns of Thought in Africa and the West: Essays on Magic, Religion, and Science, Cambridge U.K.: Cambridge University Press, 1993. Horton uses the people of New Calabar as examples in many of the essays. See Robin Horton and Ruth Finnegan (eds.), Modes of thought: Essays on Thinking in Western and Non-Western Societies, London: Faber and Faber, 1973.

${ }^{87}$ Robin Horton, 'From Fishing Village to City-State: A Social History of New Calabar', p. 37. See also footnote 7, p. 58. According to Horton writing in 1969, Jones did not 'have the opportunity to do fieldwork in the Kalabari villages' and therefore some of his work was based on information gathered from neighbouring communities.

${ }^{88}$ After publication of his book Fyfe obtained a post teaching African History without a Ph.D. Kup who worked in Sierra Leone went on to work in Canada teaching African History. Hair had the longest publishing career with over fifty years of work on the region. He taught at the University of Ibadan and the University of Khartoum between 1953 and 1965, and then at the University of Liverpool between 1965-90.

${ }^{89}$ Kup's A History of Sierra Leone 1400-1787, published in 1961, coincided with the independence of Sierra Leone from the United Kingdom. These are not the only works produced by Fyfe and Kup. While I have selected these three historians there are quite a few other English trained historians who have written about Sierra Leone since 1957. For example, there was Walter Rodney a West Indian who completed his Ph.D. in 1966 at SOAS. His dissertation was published in 1970 as A History of the Upper Guinea Coast, 1545-1800, Oxford, U.K., Oxford University Press, 1970. Rodney was killed in a bomb explosion while running for office in elections in Guyana in 1980. John Hargreaves completed an M.A. at the University of Manchester in 1948, 'Anglo-French Relations 1904-06'. He became an assistant lecturer at the University of Manchester in 1949 and then a senior history lecturer at Fourah Bay College, University of Sierra Leone between 1952 and 1954. In 1954 he became lecturer at the University of Aberdeen, and chairman of the Aberdeen University African Studies Group from its creation in 1966 until his retirement in 1983. Michael Crowder (1934-1988) was not a trained historian. After war time service in Nigeria he gained a 1st class honours degree in Politics, Philosophy and Economics at Oxford University in 1957. Crowder became the first Editor of Nigeria Magazine, 1959-1962, and Secretary at the Institute of African Studies at the University of Ibadan. Crowder became a lecturer in African History at the University of California in 1964-1965 and Director of the Institute of African Studies at the University of Sierra Leone between 1965 and 1967. Between 1968 and 1978 he was Research Professor and Director of the Institute of African Studies at the University of Ife, Nigeria, and in 1971 became Professor of History at the Ahmadu Bello University acting as the Director of its Centre for Nigerian Cultural Studies, for the period1972-1975. From 1975 to 1978 he was Research Professor in History at the Centre for Cultural Studies at the University of Lagos. In 1979 he took up the post as editor of the British magazine History Today and remained Consultant Editor up to his death in 1988. Between 1981 and 1982 he was the Visiting Fellow at the Centre for International Studies at the London School of Economics and Professor of History at the University of Botswana, 1982-85. From 1985 until his death he was also the Joint Editor of the Journal of African History. In 1986 Crowder became the Visiting Professor in Black Studies at Amherst College, Massachusetts and an Honorary Professorial Fellow and General Editor of the British Documents on the End of Empire Project at the Institute of Commonwealth Studies (ICS). For a fuller account see, Aim 25, Archives in London and the M25 area, Institute of Commonwealth Studies, 'Crowder, Michael (1934-1988)', http://www.aim25.ac.uk/cgibin/search2?coll_id=4931\&inst_id=16, last accessed 13 May 2008. Adam Jones completed his Ph.D., 'A History of the Galinhas Country, Sierra Leone, ca.1650-1890' at the Centre of West 
African Studies, University of Birmingham in 1979. Before that Jones was a teacher of history, literature and English in Sierra Leone between 1973 and 1975. Jones has also completed thirty months of field research in Sierra Leone over the years 1973-75, 1977-78, 1980 and 1984. Most of Jones's professional career involved teaching in Germany where he became a Lecturer and Heisenberg Fellow between 1989 and 94. Since 1995 he has held the post of Professor of History and Culture in Africa at the University of Leipzig. See, University of Leipzig, 'Employees, Dr. Adam Jones, Professor of History and Culture in Africa', http://translate.google.co.nz/translate?hl=en\&sl=de\&u=http://www.unileipzig.de/ afrika/\&sa $=$ X\&oi=translate\&resnum $=1 \& \mathrm{ct}=$ result\&prev $=/ \mathrm{search} \% 3 \mathrm{Fq} \% 3 \mathrm{DInstitut}$ $\% 2 \mathrm{Bf} \% 25 \mathrm{C} 3 \% 25 \mathrm{BCr} \% 2 \mathrm{BAfrikanistik} \% 26 \mathrm{hl} \% 3 \mathrm{Den} \% 26 \mathrm{sa} \% 3 \mathrm{DG}$, last accessed 13 May 2008.

${ }^{90}$ David Henige, Adam Jones, Robin Law, Bruce Mouser, Konrad Tuchscherer, Selena Winsnes, 'P.E.H. Hair, 1926-2001', History in Africa, Vol. 29, 2002, pp. 1-13. See Bruce Mouser, p. 8, 'I first met Paul in 1981 when I was attending a Sierra Leone Symposium hosted by University of Birmingham. By that date Hair was already acknowledged the most published historian of Sierra Leone, with more articles than perhaps even he could easily recollect'.

${ }^{91}$ Christopher Fyfe, 'Sierra Leone and Edinburgh', in Kirk-Greene (ed.), The Emergence of African History at British Universities, pp. 83-89.

${ }^{22}$ A.P. Kup, 'An account of the returned exiles of 1553-8 in England and Scotland', Ph.D., St Andrews, 1952. Information kindly supplied by David Henige, email 21 May 2008. I have been unsuccessful in locating more biographical details for Kup.

${ }^{93}$ Hair was the co-editor of the Liverpool Medical History Society journal Medical Historian, See Liverpool Medical History Society, 'Obituary Professor Paul E. H. Hair (1926-2001)', Medical Historian, Number 12, 2001, pp. 53-54, www.lmi.org.uk/medical_society/12/12Obituary.pdf, last accessed 13 May 2008. Hair's Ph.D. thesis was supervised by G.D.H. Cole.

${ }^{94}$ The first eighty seven pages of the six hundred and twenty of text cover the period from the fifteenth century to the beginning of the nineteenth century. There is little reference to the fifteenth, sixteenth and seventeenth centuries. By page four Fyfe begins to discus the eighteenth century and by page seventeen Fyfe is already describing the boarding of the colony expedition ships in January 1787. It is worth noting that by the end of the text Fyfe has only moved from 1787 on page seventeen to 1909 by page six hundred and twenty. Clearly Fyfe's book is a study of incredible depth on the colony.

${ }^{95}$ I have investigated Fyfe' footnotes and bibliography it is clear that he was well aware of the most important sources, such as those listed by Hair in, 'Ethnolinguistic Continuity on the Guinea Coast', The Journal of African History, Vol. 8, No. 2, 1967, pp. 247-268. see p. 249, footnote 8. Hair lists the following pre-1800 authors, D. Gomes, Cadamosto, Duarte Pacheco Pereira, V. Fernandes, A. Alvares d'Almada, F. De Lemos Coelho. Coelho was not used by Fyfe possibly because because the English translation did not appear until 1985. See English translation: P.E.H. Hair (trans. and ed.), Francisco de Lemos Coelho, Description of the Coast of Guinea (1684), Liverpool, U.K.: Dept. of History, University of Liverpool, 1985. Gomes does not appear in Fyfe's book, but reference to Blake's Europeans in West Africa, 1450-1560, shows that he was certainly aware of the source. Pereira does appear in Fyfe, but Cadamosto is in Fyfe's bibliography. Fyfe was also aware of Father Barreira's records translated into French by Du Jarric. Fernandes appears in Fyfe and included in Fernandes work was information from Alvaro Velho who lived in Sierra Leone for eight years. Alvares appears in Fyfe. Fyfe's references leave the reader in no doubt that he was clearly aware of the most important sources. ${ }^{96}$ One example for the pre-1700 period was the citation of; C.F. Schlenker, A Collection of Temne Traditions, Fables and Proverbs, London: Christian Missionary Society, 1861. For linguistic rather than oral traditions Fyfe cited C.F. Schlenker, An English Temne Dictionary, London: Christian Missionary Society, 1882, A.T. Sumner, A Handbook of the Sherbro Language, London: Crown Agents for the Colonies for the Government of Sierra Leone, 1921; A Handbook of the Temne Language, Freetown, Sierra Leone: Government Printing Office, 1917, for the pre 1700 period. For the period after 1700, Fyfe used J.F. Schön, A Grammer of the Mende Language, London: Society for Promoting Christian Knowledge, 1882, and J.F. 
Schön and S.A. Crowther, Journals, London: Society for Promoting Christian Knowledge 1842, S.W. Koelle, Outlines of a Grammar of the Vei Language, London: Church Missionary House, 1849; Polyglotta Africana, London: Church Missionary House, 1854. It should also be noted that no archaeological work was used by any of the authors mentioned in this section According to Adam Jones, writing in 1985, '[a]s far as Sierra Leone is concerned, no work specifically devoted to the nature of oral tradition has been published, despite several valuable publications on the oral literature of the Limba and Mende'. Adam Jones, 'Some Reflections on the Oral Traditions of the Galinhas Country, Sierra Leone', History in Africa, Vol. 12, 1985, pp. 151165 , see p. 151.

${ }^{97}$ Written records also increased after the abolition of the slave trade in 1807 , the transformation to a Crown colony in 1808 , and the settlement of recaptives.

${ }^{98}$ Christopher Fyfe, 'Reviewed work: A History of Sierra Leone, $1400-1787$ by Peter Kup', The Journal of African History, Vol. 2, No. 2, 1961, pp. 327-328, see p. 328. Fyfe is most scathing: 'How is a reviewer to treat such a book? To criticize it seriously is like falling into the sort of embarrassing, spoilsport pedantry one would show in explaining to a happy child that her tinsel star is not pure gold, nor her stick a magic wand'. J.D. Hargreaves, 'Reviewed work: A History of Sierra Leone, 1400-1787 by A.P. Kup', The English Historical Review, Vol. 77, No. 305, October, 1962, pp. 786-787. John Hargreaves was more polite than Fyfe in his condemnation of Kup's book, but he too notes that A History of Sierra Leone 1400- 1787 is not an accurate book on Sierra Leone or its people.

${ }^{99}$ A comparison of Kup's references with several bibliographies for Sierra Leone available before 1961 reveals that Kup did not add any new sources. See Luke, A Bibliography of Sierra Leone; Preceded by an Essay on the Origin, Character, and Peoples of the Colony and Protectorate; Hair, 'A Bibliographic Guide to Sierra Leone 1450-1650', pp. 62-72; Hair, 'A Bibliographic Guide to Sierra Leone 1650-1800', pp. 41-49.

${ }^{100}$ D.H. Jones, 'Reviewed work: A History of Sierra Leone, $1400-1787$ by A. P. Kup', Bulletin of the School of Oriental and African Studies, University of London, Vol. 24, No. 3, 1961, p. 610. At the time of the Mani invasion Sierra Leone was occupied by the Sapi peoples, the Temne and Bullom.

${ }^{101}$ P.E.H. Hair, 'An ethnolinguistic inventory of the Lower Guinea coast before 1700', African Language Review 7, 1968, pp. 47-73, see p. 49. Hair notes that there is no evidence for what Kup says or the story put forward by Walter Rodney, in 'A Reconsideration of the Mane Invasions of Sierra Leone', The Journal of African History, Vol. 8, No. 2, 1967, pp. 219-246. ${ }^{102}$ Fyfe, 'Reviewed work: A History of Sierra Leone, 1400-1787 by Peter Kup', pp. 327-328.

${ }^{103}$ In August 2001 Hair passed away. For a list of Paul Hair's publications see, Author Unknown, 'Publications of Paul Hair, 1953-2002', History in Africa, Vol. 29, 2002, pp. 15-37. ${ }^{104}$ P.E.H. Hair, Africa Encountered: European Contacts and Evidence 1450-1700, Brookfield, Vermont., USA: Variorum, 1997, p. x. Adam Jones also shifted focus from oral testimonies to textual analysis. Jones completed his Ph.D., 'A History of the Galinhas Country, Sierra Leone, C.1650-1890' in 1979 under John Fage at the Centre of West African Studies, University of Birmingham. Jones's thesis was based on a considerable amount of oral tradition gathered from fieldwork. For a description of the fieldwork he undertook see, Adam Jones, 'Some Reflections on the Oral Traditions of the Galinhas Country, Sierra Leone', History in Africa, Vol. 12, 1985, pp. 151-165. Jones noted the limitations of oral testimonies before 1800 .

${ }^{105}$ See the review by Rosalind Shaw, 'Reviewed work: An Interim Translation of Manual Alvares S.J., Etiopia Menor e Descripcao Geografica da Provincia da Serra Leoa [c. 1615] ('Ethiopia Minor and a Geographical Account of the Province of Sierra Leone') by P.E.H. Hair', Journal of Religion in Africa, Vol. 24, Fasc. 2, May, 1994, pp. 193-195. Hair worked with Avelino Teixeira da Mota on early Portuguese sources and after his death continued the compilation and translation of his sources.

${ }^{106}$ Migratory patterns are one of the greatest riddles of the pre-colonial African past. See the works by Hair; 'Ethnolinguistic continuity on the Guinea coast', pp. 247-68; 'An ethnolinguistic inventory of the Upper Guinea coast before 1700', African Language Review 6, 1967, pp. 32 70; 'An ethnolinguistic inventory of the Lower Guinea coast before 1700, pp. 47-73; 'An 
ethnolinguistic inventory of the Lower Guinea coast before 1700: Part II', African Language Review 8, 1969, pp. 225-56; and Hair 'From language to culture: some problems in the systematic analysis of the ethnohistorical records of the Sierra Leone region', in R.P. Moss and R.J.A.R. Rathbone, The Population Factor in African Studies: The Proceedings of a Conference Organized by the African Studies Association of the United Kingdom, September 1972, London: University of London Press, 1975, pp. 71-83. These are only some of Hairs work on linguistic data for a complete list see, Author Unknown, 'Publications of Paul Hair, 1953-2002', pp. 1537.

${ }^{107}$ Peter Mark, 'Reviewed work: Africa Encountered: European Contacts and Evidence, 14501700 by P. E. H. Hair', The Journal of African History, Vol. 42, No. 1, 2001, pp. 120-121. 


\section{CONCLUSION}

My thesis investigated how an academic infrastructure was developed to create the discipline of African History. This development had its antecedents in the need for the British to gain knowledge of African peoples between 1787 and 1945. This knowledge was required for trade, missionary activity, the act of colonisation and security. After the Second World War, with moves towards decolonisation, the need for African Studies increased in importance. With the creation of British African universities in 1948, African History in the United Kingdom was still very much in its formative stage. By the 1960s African History was a burgeoning field of study, both in the United Kingdom and in centres for the study of Africa that were emerging in the United States. With the recognition by pioneering Africanists that African history could be portrayed from an African perspective, the discipline gained legitimacy. This validation relied on the work of scholars who located and examined pre-colonial written sources and established African oral testimonies as valid historical evidence. Throughout the chapters of this thesis I examined and explained how infrastructural factors contributed to create, shape and present what we now know as the academic discipline of African History.

Chapter One discussed how the growth of education in British African colonies had its foundation in the colonisation of Sierra Leone in 1787. From Sierra Leone, missionary organisations extended control over British education in Africa, culminating in the establishment of university courses in affiliation with the University of Durham at the missionary-controlled Fourah Bay College in 1876. Missionaries laid the foundation for the concepts of 'trusteeship' and 'adaptation' between 1880 and the end of the First World War in 1918. In the inter-war years, missionary education partnered with government education, but gradually gave way to government control as African colonies increased in importance to the British Empire. Between 1929 and 1948 the British government put in place a formal education policy for Africa. A series of government reports between 1911 and 1945 demonstrated the British commitment to developing higher education in its African territories. The subsequent creation of universities in Africa, in Nigeria, Sudan, Ghana and Uganda not only introduced higher education but embraced a local research requirement for academic staff. By 1948, a 
pivotal moment for the discipline of African History had been reached, as formal acknowledgment was given to the study of regions previously considered as having no histories.

Chapter Two explained how in the United Kingdom an academic infrastructure developed alongside education in British African colonies, establishing the discipline of African History by the end of the 1950s. The early foundations of the discipline were laid by the writings of travellers to Africa and the efforts of private organisations. The School of Oriental Studies, University of London, evolved from these origins, opening in 1917 and in 1938 being renamed the School of Oriental and African Studies (SOAS). Until the end of the Second World War, African courses at SOAS focused on African languages for government officials and military personnel. Non-linguistic African Studies received its authorisation at SOAS from the recommendation of the Scarbrough Report (1947), with Roland Oliver appointed lecturer in African Tribal History in 1948. The same year, four new British universities opened in Africa. The Scarbrough Report formalised the official government position that recommended the expansion of African Studies in the United Kingdom and the creation of academic departments. In the mid1950s a group of pioneering historians developed the subject by organising conferences, staffing academic departments and creating scholarly publications, such as the Journal of African History. Government reports in the 1960s confirmed these developments, making African History a permanent subject in the academic curriculum in Britain.

Chapter Three demonstrated how African Studies in the United States followed from the disciplinary developments in Africa and England. African History in the United States did not emerge as the result of the U.S. Civil Rights movement, nor did it develop as an attempt to understand the connection between Africa and African descendents living in the United States as result of the Atlantic slave trade. The discipline developed in the United States as a consequence of a national need to understand a growing economic and strategic relationship between Africa and the United States. This association grew from trade during World War Two and a growing fear of Russian influence in Africa during the Cold War. The development of African Studies programmes was supported at U.S. universities by government and private funding. These university programmes were developed by key historians, who not only expanded the subject's boundaries, but influenced the following generations of 
Africanists. Thus, along with government and private foundational support, historians themselves played a role in developing the discipline's infrastructure.

Chapter Four shifted focus from government reports and the establishment of university departments in African History to examine how sources have impacted on the discipline's development. In the 1950s and 1960s historians began writing the history of Africa, and began closely examining existing source material. By looking at pre-1800 West African history this chapter demonstrated that to write African history for the period ca.1450-1800 historians must rely on a few extant written European sources or 'golden texts'. The importance of these highly-cited texts forced historians to reexamine them, which in the case of Barbot's Description of the Coasts of North and South Guinea (1678-1712), took three historians twenty years of work. The limited number of written sources also prompted historians to use oral testimonies, a traditional method of recording the past in many African societies. The pioneering works of Jan Vansina illustrated that oral testimonies were difficult to verify and required considerable analysis. In order to mine all extant sources, historians were required to learn European and African languages and to interpret oral sources. The extent to which historians had been successful was illustrated by the case study of histories produced for Sierra Leone and New Calabar. With an adequate amount of written material, the history for pre-1800 Sierra Leone relied almost exclusively on European written records. In contrast, New Calabar, with minimal written records, incorporated oral testimony to fill out the few 'golden texts'. The comparatively rich pre-1800 written material for Sierra Leone sustained the careers of three historians, Peter Kup, Christopher Fyfe and Paul Hair, enabling a greater number of comprehensive histories to be published than those produced for New Calabar.

In 2008, SOAS, CWAS, and the University of Wisconsin are still the most important centres of African History in Britain and the United States, although the focus of study within the subject has changed. Pre-1800 African history has declined as a topic of study, being replaced by interest in Africa in the nineteenth and twentieth centuries. For example, nine of the last ten African Studies Association Herskovits awards have been for works that focus predominantly on African subjects during the nineteenth and twentieth centuries. ${ }^{1}$ The one exception was the 2005 award for Emeritus Professor Jan Vansina's How Societies Are Born: Governance in West Central Africa Before 1600 (2004). ${ }^{2}$ 
The shift away from writing about the pre-1800 period in African History also can be seen in the number of articles referencing the discipline's 'golden texts' (See Table A1, Appendix A). An examination of the number of articles in the Journal of African History, which cite the major 'golden texts' referenced in chapter four, Table 6, reveals that between 1960 and 1999 there has been a reduction in their usage by historians. Between 1960 and 1989 the use of 'golden texts' remained relatively even, averaging eighty-six articles per decade. The decade 1990-1999, however, showed a major reduction, with less than fifty percent of the previous decade's usage, recording only thirty-six articles. The change of focus relates to several factors, the first being the availability of primary source material.

It is clear that African historians who examine the pre-1800 period must rely on comparatively few sources. In 1977 John Blake published a second edition of his 1937 book, European Beginnings in West Africa 1454-1578, adding a preface and re-titling it West Africa: Quest for God and Gold 1454-1578. The change in title reflects a shift from Imperial History to African History and acknowledges the importance of written accounts by missionaries and traders. In the preface of his 1977 publication, Blake noted that while many new sources had been discovered in the archives of European nations, particularly those of the Portuguese, in the forty years since his first edition no new source had significantly changed pre-colonial African history. ${ }^{3}$ Today in 2008 , with no new written sources likely to be found, the few scholars who still study pre-1800 Africa have turned to in-depth textual analysis of existing 'golden texts'. The African Studies Association instituted a prize for editing primary source texts in 1990, renaming it the Paul Hair Prize after Hair's death in 2001. This prize recognises both the importance of editing and analysing primary texts and Hair's prominence in this field. Interestingly, the prize does not reward the discovery of new pre-1800 sources.

The difficulty in obtaining oral sources for pre-1800 African history has also resulted in a shift of academic attention away from pre-colonial studies. Historians of nineteenth and twentieth-century African history generally have more reliable oral testimonies due to their closer proximity to the past. One obstacle for British and American historians is the difficulty to collect reliable oral data for the distant precolonial African past. One recent study of pre-colonial Africa, which relied on oral data, was Robert Baum's Shrines of the Slave Trade: Diola Religion and Society in 
Precolonial Senegambia (1999). In reviewing Baum's important study, Africanist Martin Klein noted that:

[i]t took Robert Baum 25 years of research, eight visits and 900 interviews before he felt he could write the history of shrines in the Diola community of Esalulu (population 15,000). ${ }^{4}$

With the length of time required to investigate pre-colonial oral sources and difficulty of access to many African societies, it is little wonder that pre-1800 African history is less prominent as an academic subject today compared to when the pioneering generation lived and worked in Africa.

Another contributing factor to the change of focus in African History is the diminishing historical connection between universities in Britain and the United States with African universities. British academics no longer staff the new independent universities in Africa. As a result of independence and political changes, foreign academics are often no longer able to spend long periods in Africa conducting fieldwork necessary for research into the distant past. Africans at local universities are now positioned to investigate their own histories. The present dynamic situation in Africa has drawn African and non-African academics, as well as government officials, to investigate the more recent past for answers to political instability. A study of recent developments in African universities would add to the findings of this thesis.

The contribution of historians, government and private educational funding created institutions where would-be Africanists can venture into a rich and dynamic history. That students of African history today can study several languages, including an African language, can learn linguistic, anthropological and archaeological methods, and at the same time be trained to analyse written and oral information, is the result of longterm infrastructural developments as well as the lasting legacy of those 'charter historians' who pioneered the discipline of African History in the 1940s, 1950s and 1960s. 


\section{Notes to Conclusion}

${ }^{1}$ For award winners see, Rutgers, The State University of New Jersey, African Studies Association Awards, 'Melville J. Herskovits Award Winners' http://www.rci.rutgers.edu/ callasa/asa_herskovitzawardwinners.html, last accessed 1 December 2008. Some of the books, like that of Joseph E. Inikori, Africans and the Industrial Revolution in England: A Study in International Trade and Economic Development. Cambridge U.K.: Cambridge University Press, 2002, have some discussion on pre-1800, but that is not the focus. They are not histories of pre-1800 Africa.

${ }^{2}$ Vanisina, How Societies Are Born.

${ }^{3}$ Blake, West Africa Quest for God and Gold 1454-1578, London: Curzon, 1977, p. xiii. Originally published as European Beginnings in West Africa 1454-1578, 1937.

${ }^{4}$ Martin A. Klein, 'The Slave Trade and Decentralized Societies', The Journal of African History, Vol. 42, No. 1, 2001, pp. 49-65, see p. 51. Robert M. Baum, Shrines of the Slave Trade: Diola Religion and Society in Precolonial Senegambia, New York, Oxford University Press, 1999. 


\section{APPENDIX}

Table A1. Occurrence of Golden Texts in Journal of African History articles between 1960 and 1999, inclusive.
(1)
(2)
(3)
(4)

Source

1960-1969

1970-1979

1980-1989

1990-1999

BARBOT,

7

7

4

3

Jean (or John)

BOSMAN,

12

21

13

Willm (or Williim)

CA' DA MOSTO,

3

7

9

3

Alvise da

CAVAZZI da

9

4

5

1

MONTECUCCOLO, G.A

DALZEL,

4

10

7

3

Archibald

DAPPER

15

15

9

5

Olfert

FERNANDES

ALEMÃO, Valentim

5

3

7

3

LABAT,

7

7

6

4

Jean-Baptiste

NORRIS,

4

9

9

3

Robert

PACHECO

11

14

15

3

PEREIRA, Duarte

Totals:

77

97

84

31

Sources: J. D. Fage, A Guide to Original Sources for Precolonial Western Africa Published in European Languages: For the Most Part in Book Form, Madison, Wisconsin: University of Wisconsin Press, 1987, second edition 1994; Journal of African History, London: Cambridge University Press, 19601999, Vols. 1-40. 


\section{BIBLIOGRAPHY}

\section{Government and Private Organisation Reports}

\section{Britain}

Cmd. 5666, Report of the Imperial Education Conference, London: H.M.S.O., 1911.

Cmd. 2374, Education Policy in British Tropical Africa, London: H.M.S.O., 1925.

Cmd. 3234, Report of the Commission on Closer Union of the Dependencies in Eastern and Central Africa, London: H.M.S.O., 1929.

Cmd. 3540, First Interim Report of the Colonial Development Advisory Committee covering the period 1st August 1929-28th February 1930, London: H.M.S.O., 1930.

Cmd. 6175, Statement of Policy on Colonial Development and Welfare, London: H.M.S.O., 1940.

Cmd. 6647, Report of the Commission on Higher Education in the Colonies, London: H.M.S.O., 1945.

Cmd. 6655, Report of the Commission on Higher Education in West Africa, London: H.M.S.O., 1945.

Cmd. 6713, Colonial Development and Welfare: Despatch dated 12th November, 1945, from the Secretary of State for the Colonies to Colonial Governments, London: H.M.S.O., 1945.

Cmd. 7331, Report of the Inter-University Council for Higher Education in the Colonies, 1946/47, London: H.M.S.O., 1948.

Foreign Office, The Report of the Interdepartmental Commission of Enquiry on Oriental, Slavonic, East European and African Studies, London: H.M.S.O., 1947, reprint 1959.

University Grants Committee, Report of the Sub-Committee on Oriental, Slavonic, East European and African Studies, London, H.M.S.O., 1961.

The Committee of Inquiry into African Education Report, Government Printer, Zomba, Nyasaland, 1962.

Cmd. 2154, (Higher Education) Report of the Committee appointed by the Prime Minister under the Chairmanship of Lord Robbins, 1961-63, London: H.M.S.O., 1963.

Colonial Office, Col. No. 103, Advisory Committee on Education in the Colonies Memorandum on the Education of African Communities, London: H.M.S.O., 1935.

\section{U.S.A.}

Higher Education For Democracy, A Report of the President's Commission on Higher Education, Six Volumes, Washington D.C.: United States Government Printing Office, 1947.

\section{Private}

African Education Commission 1920/21, Phelps-Stokes Fund, Education in Africa: A Study of West, South, and Equatorial Africa by the African Education Commission under the Auspices of the Phelps-Stokes Fund and Foreign Mission Societies of North America and Europe, New York: Phelps-Stokes Fund, 1922. 


\section{Journal Articles and Book Chapters}

Ade Ajayi, J. F., 'Towards a More Enduring Sense of History', in J. F. Ade Ajayi, History and the Nation and Other Addresses, Ibadan, Nigeria: Spectrum Books Ltd, 1990, pp. 41-43.

Austen, Ralph A., 'Reviewed work: Transformations in Slavery: A History of Slavery in Africa by Paul E. Lovejoy', The American Historical Review, Vol. 89, No. 3, June, 1984, pp. 820-821.

Author Unknown, 'The Death of Captain F. Shelford', Journal of the Royal African Society, Vol. 42, No. 169, October, 1943, p. 182.

Author Unknown, 'Fifty Years of a British African Society', African Affairs, Vol. 50, No. 200, Jubilee, July, 1951, pp. 177-195.

Author Unknown, 'African Studies in the United States', African Studies Bulletin, Vol. 1, No. 1, April, 1958, pp. 6-20.

Author Unknown, 'Report of First Annual Meeting-Sept. 8-10, 1958', African Studies Bulletin, Vol. 1, No. 2, November, 1958, pp. 12-21.

Author Unknown, 'African Studies in the United States', African Studies Bulletin, Vol. 4, No. 2, May, 1961, pp. 9-20.

Author Unknown, 'History of the African Studies Association', African Studies Bulletin, Vol. 4, No. 2, May, 1961, pp. 32-33.

Author Unknown, 'Historical Theses on African Subjects Completed in Great Britain', African Studies Bulletin, Vol. 4, No. 3, October, 1961, pp. 1-9.

Author Unknown, 'African Studies in the United States', African Studies Bulletin, Vol. 5, No. 1, March, 1962, pp. 19-28.

Author Unknown, 'Publications of Paul Hair, 1953-2002', History in Africa, Vol. 29, 2002, pp. 15-37.

Banya, Kingsley, 'Illiteracy, Colonial Legacy and Education: The Case of Modern Sierra Leone', Comparative Education, Vol. 29, No. 2, 1993, pp. 159-170.

[Blagden, Charles Otto], C.O.B., 'Obituary: Professor Alice Werner', Bulletin of the School of Oriental Studies, University of London, Vol. 8, No. 1, 1935, pp. 281282.

Blake, J. W., 'The Study of African History', Transactions of the Royal Historical Society, 4th Ser., Vol. 32, 1950, pp. 49-69.

Brokensha, David, 'African Studies in the United States', African Studies Bulletin, Vol. 7, No. 1, March, 1964, pp. 12-24.

Carter, Gwendolen M., 'African Studies in the United States: 1955-1975', A Journal of Opinion, Vol. 6, No. 2/3, Africanist Studies 1955-1975, Summer-Autumn, 1976, pp. 2-4.

Coleman, James S., 'Research on Africa in European Centers', African Studies Bulletin, Vol. 2, No. 3, August, 1959, pp. 1-33.

Cowan, L. Gray, 'Ten Years of African Studies', African Studies Bulletin, Vol. 12, No. 1, April, 1969, pp. 1-7.

Curtin, Philip D., 'Third Conference On African History and Archaeology', African Studies Bulletin, Vol. 4, No. 3, October, 1961, pp. 10-11.

'African Studies: A Personal Assessment', African Studies Review, Vol. 14, No. 3 , December, 1971, pp. 357-368.

'Recent Trends in African Historiography and their Contribution to History in General' in UNESCO General History of Africa, Vol. I, Portsmouth, New Hampshire: Heinemann, 1981, pp. 54-71. 
[Crowder, Michael] M.C., 'Roland Oliver', The Journal of African History, Vol. 29, No. 1, Special Issue in Honour of Roland Oliver, 1988, pp. 1-4.

Davis, Jackson, 'Education in British West Africa', The Journal of Negro Education, Vol. 15, No. 3, The Problem of Education in Dependent Territories, Summer, 1946, pp. 358-369.

Dressel, Carol A., 'The Development of African Studies in the United States', African Studies Bulletin, Vol. 9, No. 3, December, 1966, pp. 66-73.

D'Souza, Henry, 'External Influences on the Development of Educational Policy in British Tropical Africa from 1923 to 1939', African Studies Review, Vol. 18, No. 2, September, 1975, pp. 35-43.

Eltis, David, Paul E. Lovejoy and David Richardson, 'Slave Trading Ports: Towards an Atlantic-Wide Perspective, 1676-1832', in Robin Law and Silke Strickrodt (eds.), Ports of the Slave Trade (Bights of Benin and Biafra), Papers from a Conference of the Centre of Commonwealth Studies, University of Stirling June 1988, Stirling, U.K.: Centre of Commonwealth Studies, University of Stirling, 1999, pp. 12-34.

Emudong, Charles, Peter, 'The Gold Coast Nationalist Reaction to the Controversy over Higher Education in Anglophone West Africa and its Impact on Decision Making in the Colonial Office, 1945-47', The Journal of Negro Education, Vol. 66, No. 2, Spring, 1997, pp. 137-146.

Fage, J. D., 'Slavery and the Slave Trade in the Context of West African History', The Journal of African History, Vol. 10, No. 3. 1969, pp. 393-404.

'Continuity and Change in the Writing of West African History', African Affairs, Vol. 70, No. 280, July, 1971, pp. 236-251.

'A Commentary on Duarte Pacheco Pereira's Account of the Lower Guinea Coastlands in His "Esmeraldo de Situ Orbis", and on Some Other Early Accounts', History in Africa, Vol. 7, 1980, pp. 47-80.

'Obituary: Kenneth Onwuka Dike, 1917-83', Africa: Journal of the International African Institute, Vol. 54, No. 2, 1984, pp. 96-98.

'British African Studies since the Second World War: A Personal Account', African Affairs, Vol. 88, No. 352, July, 1989, pp. 397-413.

'African Societies and the Atlantic Slave Trade', Past and Present, No. 125, November, 1989, pp. 97-115.

'Reflections on the Genesis of Anglophone African History after World War II', History in Africa, Vol. 20, 1993, pp. 15-26.

'Review: 'Good Red Herring': The Definitive Barbot', The Journal of African History, Vol. 34, No. 2, 1993, pp. 315-320.

Finan, John J., 'Howard F. Cline (1915-1971)', The Hispanic American Historical Review, Vol. 51, No. 4, November, 1971, pp. 646-653.

Flint, John, 'Planned Decolonization and Its Failure in British Africa', African Affairs, Vol. 82, No. 328, July, 1983, pp. 389-411.

Fyfe, Christopher, 'Reviewed work: A History of Sierra Leone, 1400-1787 by Peter Kup', The Journal of African History, Vol. 2, No. 2, 1961, pp. 327-328.

'A. B. C. Sibthorpe: A Tribute', History in Africa, Vol. 19, 1992, pp. 327-352. 'Sierra Leone and Edinburgh', in Kirk-Greene (ed.), The Emergence of African History at British Universities: An Autobiographical Approach, Oxford: Worldview Publications, 1995, pp. 83-89.

Genovese, Eugene D., 'Reviewed work: The Atlantic Slave Trade: A Census by Philip D. Curtin', The American Historical Review, Vol. 75, No. 7, December, 1970, p. 2011. 
Gilchrist, Huntington, 'Trusteeship and the Colonial System', Proceedings of the Academy of Political Science, Vol. 22, No. 2, Developing a Working International Order: Political, Economic and Social, January, 1947, pp. 95-109.

Gordon, Jacob U., 'Teaching the African Experience: A Pan-Africanist Approach', African Studies Review, Vol. 19, No. 3, December, 1976, pp. 109-117.

Hair, P. E. H., 'A Bibliographic Guide to Sierra Leone 1450-1650', Sierra Leone Studies, No. 10, 1958, pp. 62-72.

'A Bibliographic Guide to Sierra Leone 1650-1800', Sierra Leone Studies, No. 13, 1960, pp. 41-49.

'The Spelling and Connotation of the Toponym "Sierra Leone" since 1461', Sierra Leone Studies, No. 18, Freetown, 1966, pp. 43-58.

'Ethnolinguistic continuity on the Guinea coast', Journal of African History, Vol. 8, 1967, pp. 247-68.

'An ethnolinguistic inventory of the Upper Guinea coast before 1700', African Language Review 6, 1967, pp. 32-70.

'An ethnolinguistic inventory of the Lower Guinea coast before 1700', African Language Review 7, 1968, pp. 47-73.

'An ethnolinguistic inventory of the Lower Guinea coast before 1700: Part II', African Language Review 8, 1969, pp. 225-56.

'From language to culture: some problems in the systematic analysis of the ethnohistorical records of the Sierra Leone region' in R. P. Moss and R. J. A. R.

Rathbone, The Population Factor in African Studies: The Proceedings of a Conference Organized by the African Studies Association of the United Kingdom, September 1972, London: University of London Press, 1975, pp. 71-83.

'Some Minor Sources for Guinea, 1519-1559: Enciso and Alfonce Fonteneau', History in Africa, Vol. 3, 1976, pp. 19-46.

'The Editing of Early European-Language Texts on Black Africa', in Beatrix Heintze and Adam Jones (eds.), 'European sources for Sub-Saharan Africa before 1900: Use and Abuse', Paideuma 33, Stuttgart, 1987, pp. 29-51.

'J.W. Blake: A Tribute', History in Africa, Vol. 16, 1989, pp. 413-414.

'Jesuit Documents on the Guinea of Cape Verde and the Cape Verde Islands, 1585-1617 in English Translation', History in Africa, Vol. 16, 1989, pp. 375-381.

'On Editing Barbot', History in Africa, Vol. 20, 1993, pp. 53-59.

'The Early Sources on Guinea', History in Africa, Vol. 21, 1994, pp. 87-126.

'The History of the Baga in early Written Sources', History in Africa, Vol. 24, 1997, pp. 381-391.

'Christian Influences in Sierra Leone before 1787', Journal of Religion in Africa, Vol. 27, Fasc. 1, West African Christian History: A Tribute to A. F. Walls, the Journal's Founding Editor, Thirty Years on, February, 1997, pp. 3-14. 'Franciscan Missionaries and the 1752 'Donation of Sierra Leone', Journal of Religion in Africa, Vol. 30, Fasc. 4, November, 2000, pp. 408-432.

Hall, H. Duncan, 'The British Commonwealth and Trusteeship', International Affairs, Vol. 22, No. 2, March, 1946, pp. 199-213.

Hanke, Lewis, 'The Development of Latin-American Studies in the United States, 1939-1945', The Americas, Vol. 4, No. 1, July, 1947, pp. 32-64.

Hargreaves, J. D., 'Reviewed work: A History of Sierra Leone, 1400-1787 by A. P. Kup', The English Historical Review, Vol. 77, No. 305, October, 1962, pp. 786787.

'Reviewed work: A History of Sierra Leone by Christopher Fyfe', The English Historical Review, Vol. 79, No. 312, July, 1964, pp. 570-571. 
'The Idea of a Colonial University', African Affairs, Vol. 72, No. 286, January, 1973, pp. 26-36.

'Reviewed work: Economic Change in Pre-Colonial Africa: Senegambia in the Era of the Slave Trade by Philip D. Curtin', The International Journal of African Historical Studies, Vol. 8, No. 4, 1975, pp. 724-726.

Henige, David, 'On Method: An Apologia and a Plea', History in Africa, Vol. 1, 1974 , pp. 1-7.

'The Race is not Always to the Swift', in Beatrix Heintze and Adam Jones (eds.), 'European sources for Sub- Saharan Africa before 1900: Use and Abuse', Paideuma 33, Stuttgart, 1987, pp. 53-79.

_ Adam Jones, Robin Law, Bruce Mouser, Konrad Tuchscherer, Selena Winsnes, 'P.E.H. Hair, 1926-2001', History in Africa, Vol. 29, 2002, pp. 1-13.

Honter, R. F., 'Notes on the Psychology of the Negro Child and on the Adaption of Primitive Customs, Manners and Traditions in a System of Education' in [Cmd. 5666] Report of the Imperial Education Conference, London: H.M.S.O., 1911, pp. 228-337.

Horton, Robin, 'The Kalabari World-View: An Outline and Interpretation', Journal of the International African Institute, Vol. 32, No. 3, July, 1962, pp. 197-220. 'From Fishing Village to City-State: A Social History of New Calabar', pp. 37-58 in Mary Douglas and Phyllis M. Kaberry (eds.), Man in Africa: Essays in Honour of the Late Professor Daryll Forde, London: Tavistock, 1969.

Hyden, Goran, 'African Studies in the Mid-1990s: Between Afro-Pessimism and Amero-Skepticism', African Studies Review, Vol. 39, No. 2, September, 1996, pp. $1-17$.

Inikori, J. E., 'Measuring the Atlantic Slave Trade: An Assessment of Curtin and Anstey', The Journal of African History, Vol. 17, No. 2, 1976, pp. 197-223. 'Measuring the Atlantic Slave Trade: A Rejoinder', The Journal of African History, Vol. 17, No. 4, 1976, pp. 607-627.

'Ideology versus the Tyranny of Paradigm: Historians and the Impact of the Atlantic Slave Trade on African Societies', African Economic History, No. 22, 1994, pp. 37-58.

Johnson, Hildegard Binder, 'The Location of Christian Missions in Africa', Geographical Review, Vol. 57, No. 2, April, 1967, pp. 168-202.

Jones, Adam, 'Double Dutch? A Survey of Seventeenth-Century German Sources for West African History', History in Africa, Vol. 9, 1982, pp. 141-153.

'Reviewed work: Journal of the Historical Society of Sierra Leone, Vol. I, Nos. 12, (1977)', The International Journal of African Historical Studies, Vol. 15, No. 4, 1982, pp. 754-756.

'Some Reflections on the Oral Traditions of the Galinhas Country, Sierra Leone', History in Africa, Vol. 12, 1985, pp. 151-165.

'Semper Aliquid Veteris: Printed Sources for the History of the Ivory and Gold Coasts, 1500-1750', The Journal of African History, Vol. 27, No. 2, Special Issue in Honour of J. D. Fage, 1986, pp. 215-235.

'Decompiling Dapper: A Preliminary Search for Evidence', History in Africa, Vol. 17, 1990, pp. 171-209.

Jones, D. H., 'II Conference on History and Archaeology in Africa, 16-18 July, 1957', Man, Vol. 57, October, 1957, pp. 151-152.

'Reviewed work: A History of Sierra Leone, $1400-1787$ by A. P. Kup', Bulletin of the School of Oriental and African Studies, University of London, Vol. 24, No. 3, 1961, p. 610. 
Jones, G. I., 'European and African Tradition on the Rio Real', The Journal of African History, Vol. 4, No. 3, 1963, pp. 391-402.

'Time and Oral Tradition with Special Reference to Eastern Nigeria', The Journal of African History, Vol. 6, No. 2, 1965, pp. 153-160.

Kingsley, Mary, 'Life in West Africa', in W. M. Sheowring (ed.), The British Empire Series, Volume 2: British Africa, London: K. Paul, Trench, Trubner and Co., 1899, pp. 366-380.

'Nursing in West Africa', Chamber's Journal, June, 1900, pp. 369-371.

'Fishing in West Africa', National Review, May, 1896, pp. 213-227.

'Travels on the Western Coast of Equatorial Africa', Scottish Geographical Magazine, Vol. 12, March, 1896, pp. 113-124.

Kirk-Greene, A. H. M., 'Reviewed work: European Sources for Sub-Saharan Africa before 1900: Use and Abuse by Beatrix Heintze; Adam Jones', Bulletin of the School of Oriental and African Studies, University of London, Vol. 51, No. 3, 1988, pp. 614-615.

Klein, Martin A., 'The Slave Trade and Decentralized Societies', The Journal of African History, Vol. 42, No. 1, 2001, pp. 49-65.

'Reviewed work: Transformations in Slavery: A History of Slavery in Africa by Paul Lovejoy', Canadian Journal of African Studies / Revue Canadienne des Études Africaines, Vol. 36, No. 2, 2002, pp. 390-391.

Law, Robin, 'Jean Barbot as a Source for the Slave Coast of West Africa', History in Africa, Vol. 9, 1982, pp. 155-173.

'Early European Sources Relating to the Kingdom of Ijebu (1500-1700): A Critical Survey', History in Africa, Vol. 13, 1986, pp. 245-260.

'The Komenda Wars, 1694-1700: A Revised Narrative', History in Africa; 2007, Vol. 34, pp. 133-168.

Lawrence, W., 'Some Source Books for West African History', The Journal of African History, Vol. 2, No. 2, 1961, pp. 227-234.

Legters, Lyman H., 'The National Defense Education Act and African Studies', African Studies Bulletin, Vol. 7, No. 3, October, 1964, pp. 3-10.

Lovejoy, Paul E., 'The Volume of the Atlantic Slave Trade: A Synthesis', The Journal of African History, Vol. 23, No. 4, 1982, pp. 473-501.

'The Impact of the Atlantic Slave Trade on Africa: A Review of the Literature', The Journal of African History, Vol. 30, No. 3, 1989, pp. 365-394.

Mark, Peter, 'The Evolution of 'Portuguese' Identity: Luso-Africans on the Upper Guinea Coast from the Sixteenth to the Early Nineteenth Century', The Journal of African History, Vol. 40, No. 2, 1999, pp. 173-191.

'Reviewed work: Africa Encountered: European Contacts and Evidence, 14501700 by P. E. H. Hair', The Journal of African History, Vol. 42, No. 1, 2001, pp. 120-121.

McCracken, John, 'African History in British Universities: Past, Present and Future', African Affairs, Vol. 92, No. 367, April, 1993, pp. 239-253.

Miller, Joseph C., 'History and Africa/Africa and History', The American Historical Review, Vol. 104, No. 1, February, 1999, pp. 1-32.

Newbury, David, 'Contradictions at the Heart of the Canon: Jan Vansina and the Debate over Oral Historiography in Africa, 1960-1985', History in Africa, 34, 2007, pp. 213-254.

Newton, Arthur Percival, 'Africa and Historical Research', Journal of the Royal African Society, Vol. 22, No. 88. July, 1923, pp. 266-277. 
Nwaubani, Ebere, 'Kenneth Onwuka Dike, "Trade and Politics", and the restoration of the African in History', History in Africa, Vol. 27, 2000, pp. 229-248.

Ofcansky, Thomas P., 'A Bio-Bibliography of F. D. Lugard', History in Africa, Vol. 9, 1982, pp. 209-219.

Oliver, Roland, 'African History: SOAS and Beyond', in Kirk-Greene (ed.), The Emergence of African History at British Universities: An Autobiographical Approach, Oxford, U.K.: Worldview Publications, 1995, pp. 13-38. 'Reviewed Work: Paths toward the Past: African Historical Essays in Honor of Jan Vansina by Robert W. Harms; Joseph C. Miller; David S. Newbury; Michele D. Wagner', The Journal of African History, Vol. 37, No. 1, 1996, pp. 119-120.

Ottenberg, Simon, 'In Memoriam: G. I. Jones, 1904-1995', African Arts, Vol. 28, No. 3, Summer, 1995, pp. 21-21.

Phillips, David (ed.), Oxford Review of Education, Vol. 14, No. 1, The Legacy of Robbins, 1988, pp. 1-124.

Porter, Arthur T., 'Religious Affiliation in Freetown, Sierra Leone', Africa: Journal of the International African Institute, Vol. 23, No. 1, January, 1953, pp. 3-14.

Priestly, M., and I. Wilks, 'The Ashanti Kings in the Eighteenth Century: a Revised Chronology', Journal of African History, Vol. 1, 1960, pp. 83-96.

Ranger, T. O., 'Towards A Usable African Past', in Christopher Fyfe (ed.), African Studies Since 1945: A Tribute to Basil Davidson, London: Longman, 1976, pp. 1730.

'Concluding Remarks', in A. H. M. Kirk-Greene (ed.), The Emergence of African History at British Universities: An Autobiographical Approach, Oxford, U.K.: Worldview Publications, 1995, pp. 165-179.

Rathbone, Richard, 'Review: Albert van Dantzig; Adam Jones (trans. and eds.), Description and Historical Account of the Gold Kingdom of Guinea (1602), by Pieter de Marees', Bulletin of the School of Oriental and African Studies, University of London, Vol. 52, No. 2, 1989, p. 406.

Rauch, Jerome S., 'Area Institute Programs and African Studies', The Journal of Negro Education, Vol. 24, No. 4, Autumn, 1955, pp. 409-425.

[Rimmer, Douglas] D. R., 'John Donnelly Fage', The Journal of African History, Vol. 27, No. 2, Special Issue in Honour of J.D. Fage, 1986, pp. 193-201,

Rimmington, Gerald T., 'The Development of Universities in Africa', Comparative Education, Vol. 1, No. 2, March, 1965, pp. 105-112.

Roberts, A. D., 'The Sub-Imperialism of the Baganda', The Journal of African History, Vol. 3, No. 3, 1962, pp. 435-450.

'Reviewed work: The Chronology of Oral Tradition: Quest for a Chimera by David P. Henige', Bulletin of the School of Oriental and African Studies, University of London, Vol. 38, No. 3, 1975, pp. 692-693.

'The Earlier Historiography of Colonial Africa', History in Africa, Vol. 5, 1978, pp. 153-167.

— Chapter 30, 'The British Empire in Tropical Africa: A Review of the Literature to the 1960s', in Wm. Roger Louis (ed.), The Oxford History of the British Empire, vol. V, Historiography, Oxford U.K.: Oxford University Press, 1999, pp. 463-485.

Rodney, Walter, 'African Slavery and Other Forms of Social Oppression on the Upper Guinea Coast in the Context of the Atlantic Slave-Trade', The Journal of African History, Vol. 7, No. 3, 1966, pp. 431-443.

'A Reconsideration of the Mane Invasions of Sierra Leone', The Journal of African History, Vol. 8, No. 2, 1967, pp. 219-246. 
Russell, John Dale, 'Basic Conclusions and Recommendations of the President's Commission on Higher Education', Journal of Educational Sociology, Vol. 22, No. 8, Report of the President's Commission on Higher Education, April, 1949, pp. 493-508.

Ryder, A. F. C., 'A Reconsideration of the Ife-Benin Relationship', The Journal of African History, Vol. 6, No. 1, 1965, pp. 25-37.

Sbrega, John J., 'Determination versus Drift: The Anglo-American Debate over the Trusteeship Issue, 1941-1945', The Pacific Historical Review, Vol. 55, No. 2, May, 1986, pp. 256-280.

Scott, Peter, 'Blueprint or Blue Remembered Hills? The Relevance of the Robbins Report to the Present Reforms of Higher Education', in David Phillips (ed.), Oxford Review of Education, Vol. 14, No. 1, The Legacy of Robbins, 1988, pp. 33-48.

Shaw, Rosalind, 'Reviewed work: An Interim Translation of Manual Alvares S.J., Etiopia Menor e Descripcao Geografica da Provincia da Serra Leoa [c. 1615] ('Ethiopia Minor and a Geographical Account of the Province of Sierra Leone') by P.E.H. Hair', Journal of Religion in Africa, Vol. 24, Fasc. 2, May, 1994, pp. 193-195.

Shelford, Frederic, speech reproduced in, 'The African Society Inaugural Meeting', Journal of the Royal African Society, Vol. 1, No. 1, October, 1901, pp. i-xx. 'Some Notes on the History of the African Society', Journal of the Royal African Society, Vol. 34, No. 136, July 1935, pp. 223-226.

Sinclair, William, 'The African Association of 1788', Journal of the Royal African Society, Vol. 1, No. 1, October, 1901, pp. 145-149.

Skidmore, Thomas E., 'Studying the History of Latin America: A Case of Hemispheric Convergence', Latin American Research Review, Vol. 33, No. 1, 1998, pp. 105127.

Skinner, Elliott P., 'African Studies, 1955-1975: An Afro-American Perspective', $A$ Journal of Opinion, Vol. 6, No. 2/3, Africanist Studies 1955-1975, SummerAutumn, 1976, pp. 57-67.

Stopford-Green, Alice, 'Mary Kingsley', Journal of the Royal African Society, Vol. 1, No. 1, October, 1901, pp. 1-16.

Sutton, Francis X., and David R. Smock, 'The Ford Foundation and African Studies', $A$ Journal of Opinion, Vol. 6, No. 2/3, Africanist Studies 1955-1975, SummerAutumn, 1976, pp. 68-72.

Thompson, Leonard M., 'African History in the United States', African Studies Bulletin, Vol. 10, No. 1, April, 1967, pp. 51-56.

Thornton, John K., 'Traditions, Documents, and the Ife-Benin Relationship', History in Africa, Vol. 15, 1988, pp. 351-362.

'Reviewed work: Transformations in Slavery: A History of Slavery in Africa by Paul Lovejoy', The International Journal of African Historical Studies, Vol. 34, No. 1, 2001, pp. 159-160.

Trevor-Roper, Hugh, 'The Past and Present: History and Sociology', Past and Present, Vol. 42, No. 1, 1969, pp. 3-17.

[Turner, Ralph. L. (Sir)] R. L. T., 'Obituary: Lawrence Roger Lumley, 11th Earl of Scarbrough, K. G., P. C., G. C. S. I., G. C. I. E., G. C. V. O., 27 July 1896-29 June 1969', Bulletin of the School of Oriental and African Studies, University of London, Vol. 32, No. 3, 1969, pp. 686-689. 
Van Dantzig, Albert, and Willem Bosman, 'Willem Bosman's "New and Accurate Description of the Coast of Guinea”: How Accurate Is It?', History in Africa, Vol. 1, 1974, pp. 101-108.

'English Bosman and Dutch Bosman: A Comparison of Texts', History in Africa, Vol. 2, 1975, pp. 185-216.

'English Bosman and Dutch Bosman: A Comparison of Texts, II', History in Africa, Vol. 3, 1976, pp. 91-126.

'English Bosman and Dutch Bosman: A Comparison of Texts: III', History in Africa, Vol. 4, 1977, pp. 247-273.

'English Bosman and Dutch Bosman: A Comparison of Texts: IV', History in Africa, Vol. 5, 1978, pp. 225-256.

'English Bosman and Dutch Bosman: A Comparison of Texts: V', History in Africa, Vol. 6, 1979, pp. 265-285.

'English Bosman and Dutch Bosman. A Comparison of Texts: VI', History in Africa, Vol. 7, 1980, pp. 281-291.

'English Bosman and Dutch Bosman: A Comparison of Texts: VII', History in Africa, Vol. 9, 1982, pp. 285-302.

'English Bosman and Dutch Bosman: A Comparison of Texts: VIII', History in Africa, Vol. 11, 1984, pp. 307-329.

Vansina, Jan, 'Ethnohistory in Africa', Ethnohistory, Vol. 9, No. 2, Spring, 1962, pp. 126-136.

'Historians, are Archaeologists your siblings?' History in Africa, 22, 1995, pp. 369-408.

'Reviewed work: Benin and the Europeans $1485-1897$ by Alan F. C. Ryder', Africa: Journal of the International African Institute, Vol. 40, No. 4, October, 1970, pp. 384-385.

Wallbank, T. Walter, 'Educational Renaissance in British Tropical Africa', The Journal of Negro Education, Vol. 3, No. 1, January, 1934, pp. 105-122.

'Achimota College and Educational Objectives in Africa', The Journal of Negro Education, Vol. 4, No. 2, April, 1935, pp. 230-245.

White, Bob W., 'Talk about School: Education and the Colonial Project in French and British Africa, (1860-1960)', Comparative Education, Vol. 32, No. 1, March, 1996, pp. 9-25.

Wright, Donald R., 'Requiem for the Use of Oral Tradition to Reconstruct the Precolonial History of the Lower Gambia' History in Africa, Vol. 18, 1991, pp. 399-408.

\section{Books}

Addae, Stephen, The Gold Coast and Achimota in the Second World War, Ghana: Sedco Publishing, 2001.

Adams, Captain John, Sketches taken during ten voyages to Africa between the years 1786 and 1800, London: Hurst \& Robinson, 1822.

- Remarks on the country extending from Cape Palmas to the river Congo, London: G. \& W. B. Whittaker, 1823.

Ashby, Eric, African Universities and Western Tradition: The Godkin Lectures at Harvard University 1964, Cambridge, Massachusetts: Harvard University Press, 1964.

— Universities: British, Indian, African: A Study in the Ecology of Higher Education, London: Weidenfeld and Nicolson, 1966. 
Ayandele, E. A., Holy Johnson: Pioneer of African Nationalism, 1836-1917, New York: Humanities Press, 1970. African Historical Studies, London: Frank Cass, 1979.

Baum, Robert M., Shrines of the Slave Trade: Diola Religion and Society in Precolonial Senegambia, New York, Oxford University Press, 1999.

Blake, J. W., European Beginnings in West Africa 1454-1578, London: Longmans Green, 1937.

Europeans in West Africa 1450-1560: Documents to illustrate the nature and scope of Portuguese enterprise in West Africa, the abortive attempt of Castilians to create an empire there, and the early English voyages to Barbary and Guinea, Volume I, London: Hakluyt Society, 1942.

_ Europeans in West Africa 1450-1560: Documents to illustrate the nature and scope of Portuguese enterprise in West Africa, the abortive attempt of Castilians to create an empire there, and the early English voyages to Barbary and Guinea, Volume II, London: Hakluyt Society, 1942.

West Africa Quest for God and Gold 1454-1578, London: Curzon, 1977.

Bosman, William, with an introduction by J.R. Willis, and notes and appendix by J. D. Fage and R. E. Bradbury, A New and Accurate Description of the Coast of Guinea: Divided into the Gold, the Slave, and the Ivory Coasts, (1704), Fourth English edition, London: Frank Cass, 1967.

Brasio, A., Monumenta Missionaria Africana, Africa Ocidental, 2nd ser., 4, Lisbon: Agência Geral do Ultramar: Academia Portuguesa de História, 1968.

Clements, Keith, Faith on the Frontier: A Life of J. H. Oldham, Edinburgh: T. \& T. Clark, 1999.

Crooks, J. J., A History of the Colony of Sierra Leone, Dublin, Browne and Nolan 1903, reprint, London: Cass, 1972.

Crow, Captain Hugh, Memoirs of the Late Capt. Hugh Crow, London: Longman, Rees, Orme, Brown, and Green, 1830, reprint Frank Cass \& Co. Ltd., 1970.

Curtin, Philip D., The Image of Africa: British Ideas and Action, 1780-1850, Madison, Wisconsin: University of Wisconsin Press, 1964.

- Africa Remembered: Narratives by West Africans from the Era of the Slave Trade, Madison, Wisconsin: University of Wisconsin Press, 1967.

_ The Atlantic Slave Trade: A Census, Madison, Wisconsin: University of Wisconsin Press, 1969.

_Economic Change in Pre-Colonial Africa: Senegambia in the Era of the Slave Trade, 2 vols., Madison, Wisconsin: University of Wisconsin Press, 1975.

On the Fringes of History: A Memoir, Athens Ohio: Ohio University Press, 2005.

Dapper, Olfert, (translated by John Ogilby), Africa: Being Accurate Description of the Regions of AEgypt, Barbary, Lybia, and Billendulgerid, the Land of Negroes, Guinee, Athiopia, and the Abyssines, with all the Adjacent Islands, either in the Mediterranean, Atlantick, Southern, or Oriental Sea, Belonging Thereunto, London: Thomas Johnson, 1670.

Dike, K. Onwuka, Trade and Politics in the Niger Delta 1830-1885, Oxford, U.K.: Oxford University Press, 1956.

Du Bois, W.E. Burghardt, The Negro, New York: Henry Holt and Company, 1915.

Duignan, Peter, and L. H. Gann, The United States and Africa: A History, London: Cambridge University Press, 1987.

Fage, J. D., Ghana: A Historical Interpretation, Madison, Wisconsin: University of Wisconsin Press, 1959. 
- On the Nature of African History: an inaugural lecture delivered in the University of Birmingham on the $10^{\text {th }}$ of March 1965, Birmingham, U.K.: University of Birmingham, 1965.

—_ (ed.), Africa Discovers Her Past, London: Oxford University Press, 1970. A Guide to Original Sources for Precolonial Western Africa Published in European Languages: For the Most Part in Book Form, Madison, Wisconsin: University of Wisconsin Press, 1987, second edition 1994.

To Africa and Back, Birmingham, U.K.: University of Birmingham, 2002.

Flattau, Pamela Ebert, (Project Leader), with Jerome Bracken, Richard Van Atta, Ayeh Bandeh-Ahmadi, Rodolfo de la Cruz, Kay Sullivan, 'The National Defense Education Act of 1958: Selected Outcomes', Washington D.C.: Institute For Defense Analyses Science \& Technology Policy Institute, 2006.

Fyfe, Christopher, A Short History of Sierra Leone, London: Longman, 1962,

— A History of Sierra Leone, London: Oxford University Press, 1962.

— Sierra Leone Inheritance, London: Oxford University Press 1964.

- Africanus Horton, 1835-1883, West African Scientist and Patriot, New York: Oxford University Press, 1972.

— (ed.), African Studies Since 1945: A Tribute to Basil Davidson, London: Longman, 1976.

Fyle, C. Magbaily, The History of Sierra Leone: A Concise Introduction, London: Evans Brothers, 1981.

Guerreiro, Fernao, Relaçam anual das cousas que fizeram os Padres da Companhia de Jesus nas partes da Padres daIndi Oriental en emalguas outras...Tirado tudo das Cartas dos mesmos Padres... Lisbon: Pedro Crasbeeck, 1603-11, reprinted by A. Viegas three volumes, Coimbra: Imp. da Universidade, 1930-42.

— (trans. Pierre du Jarric), Histoire des choses les plus mémorables tant ez Indes Orientales, que autres pais de la descouverte des Portugais...et principalement de ce que les Religieux de la Compagnie de Jésus y ont faict.... Bordeaux: S. Millanges, 1608-14.

Hall, Robert B., Area Studies, with Special Reference to their implications for Research in the Social Sciences, Social Science Research Council Pamphlet 3, New York: Social Science Research Council, 1949.

Hair, P. E. H., (trans. and ed.), Francisco de Lemos Coelho, Description of the Coast of Guinea (1684), Liverpool, U.K.: Dept. of History, University of Liverpool, 1985. Africa Encountered: European Contacts and Evidence 1450-1700, Brookfield, Vermont., USA: Variorum, 1997.

Hair, P. E. H., Adam Jones and Robin Law (eds.), Barbot on Guinea: The Writings of Jean Barbot on West Africa, 1678-1712, 2 vols., London: Hakluyt Society, 1992.

Hallett, Robin (ed.), Records of the African Association, Edinburgh: Nelson, 1964.

Hamilton, R. A., (ed.), with a foreword by C. H. Philips, History and Archaeology in Africa: Report of a Conference held in July 1953 at the School of Oriental \& African Studies, London: School of Oriental and African Studies, University of London, 1955.

Harms, R., J. Miller, D. Newbury and M. Wagner (eds.), Paths Toward the Past: African Historical Essays in Honour of Jan Vansina, Atlanta, Georgia: African Studies Association Press, 1994.

Henige, David, The Chronology of Oral Tradition: Quest for a Chimera, Oxford, U.K.: Clarendon Press, 1974. Oral Historiography, London: Longman, 1982. 
— In Search of Columbus: The Sources for the First Voyage, Tucson, Arizona: The University of Arizona Press, 1991.

_ Historical Evidence and Argument, Madison, Wisconsin: University of Wisconsin Press, 2005.

Holden, Edith, Blyden of Liberia: An Account of the Life and Labors of Edward Wiimot Blyden, LL.D., As Recorded in Letters and in Print, New York: Vantage Press, 1966.

Horton, Robin, The Gods as Guests: An Aspect of Kalabari Religious Life, Third in the series of special Nigeria Magazine publications, Lagos: Nigeria Magazine, 1960.

— Patterns of Thought in Africa and the West: Essays on Magic, Religion, and Science, Cambridge U.K.: Cambridge University Press, 1993.

Horton, Robin, and Ruth Finnegan (eds.), Modes of Thought: Essays on Thinking in Western and Non-Western Societies, London: Faber and Faber, 1973.

Hunwick, John, and Nancy Cawler (eds.), The Cloth of Many Coloured Silks: Papers on History and Society Ghanian and Islamic in Honor of Ivor Wilks, Evanston, Illinous: Northwestern University Press, 1996.

Inikori, Joseph E. (ed.), Forced Migration: The Impact of the Export Slave Trade on African Societies, New York: 1982.

- Africans and the Industrial Revolution in England: A Study in International Trade and Economic Development. Cambridge U.K.: Cambridge University Press, 2002.

Jones, Adam, Raw, Medium, Well-Done: A Critical Review of Editorial and QuasiEditorial Work on Pre-1885 European Sources for Sub-Saharan Africa, 19601986, Madison, Wisconsin: University of Wisconsin Press, 1987.

— (trans. and ed.), West Africa in the Mid-Seventeenth Century: An Anonymous Dutch Manuscript, Atlanta, Georgia: African Studies Association Press, 1995. (ed.), Olfert Dapper's Description of Benin (1688), Madison, Wisconsin: University of Wisconsin Press, 1998.

Jones, D. H. (ed.), History and Archaeology in Africa: Second Conference held in July 1957 at the School of Oriental and African Studies, London: School of Oriental and African Studies, University of London, 1959.

Jones, G. I., The Trading States of the Oil Rivers: A Study of Political Development in Eastern Nigeria, London: Oxford University Press, 1963.

July, Robert W., A History of the African People, Prospect Heights, Illinois: Waveland Press, 1992.

_ An African Voice: The Role of Humanities in African Independence, Durham, North Carolina: Duke University Press, 1987.

Kingsley, Mary, Travels in West Africa, Congo Français, Corisco and Cameroons London: Macmillan \& Co. Ltd., 1897.

West African Studies, London: Macmillan \& Co. Ltd., 1899.

- The Story of West Africa, The Story of the Empire Series, London: Horace Marshall, 1900.

Koelle, S. W., Outlines of a Grammar of the Vei Language, London: Church Missionary House, 1849.

- Polyglotta Africana, London: Church Missionary House, 1854.

Kup, A. P., A History of Sierra Leone, 1400-1787, Cambridge U.K.: Cambridge University Press, 1961.

Sierra Leone: A Concise History, New York: St. Martin, 1975.

Louis, Wm. Roger (ed.), The Oxford History of the British Empire, vol. V, Historiography, Oxford U.K.: Oxford University Press, 1999. 
Lovejoy, Paul, Transformation in Slavery: A History of Slavery in Africa, Cambridge U.K.: Cambridge University Press, 1983, Second edition 2000. (ed.), Africans in Bondage: Studies in Slavery and the Slave Trade: Essays in Honor of Philip D. Curtin on the Occasion of the Twenty-fifth Anniversary of African Studies at the University of Wisconsin, Wisconsin, 1986.

Lugard, F. D. (Sir), The Dual Mandate in British Tropical Africa, Edinburgh: William Blackwood and Sons, 1922.

Luke, Harry Charles Joseph [Sir], A Bibliography of Sierra Leone; Preceded by an Essay on the Origin, Character, and Peoples of the Colony and Protectorate, Oxford U.K.: Clarendon press, 1910, reprint London: Oxford University Press, 1925, reprint of 1925 edition, New York: Negro Universities Press, 1969.

Lynch, R., Edward Wilmot Blyden: Pan-Negro Patriot, London: Oxford University Press, 1967.

— (ed.), Black Spokesman: Selected Published Writings of Edward Wilmot Blyden, London: Frank Cass, 1971.

MacQueen, James, A Geographical Survey of Africa, Its Rivers, Lakes, Mountains, Productions, States, Population, \&c. With a Map on an Entirely New Construction To Which is Prefixed a Letter to Lord John Russell Regarding the Slave Trade and the Improvement of Africa, London: B. Fellowes, 1840, Facsimile reprint of first edition, London: Cass, 1969.

Mauny, R. (ed.), Pereira, Duarte, Pacheco, Esmeraldo de situ orbis, (1507), French translation Côte occidentale d' Afrique, Bissau: Centro de studio de Guiné portuguesa, 1956.

Maxwell, I. C. M., Universities in Partnership: The Inter-University Council and the Growth of Higher Education in Developing Countries 1946-70, Edinburgh: Scottish Academic Press Ltd, 1980.

McKay, Vernon, Africa In World Politics, New York: Harper \& Row, 1963.

Monod, T., A. Teixeira da Mota, and R. Mauny, (eds.), Fernandes, V., Description de la Côte Occidentale d'Afrique, (1508), Bissau: Centro de estudios da Guiné portuguesa, 1951.

Monod, T., R. Mauny and G. Duval, (eds.), Gomes, D., De prima inventione Gujnee, (1448), French translation De la première découverte de la Guinée, Bissau: Centro de studio de Guiné portuguesa, 1959.

Nicol, Davidson (ed.), Africanus Horton: The Dawn of Nationalism in Modern Africa: Extracts from the Political, Educational and Scientific Writings of J.A.B. Horton M.D., 1835-1883, London: Longman, 1969.

Northrup, David, Trade Without Rulers: Pre-Colonial Economic Development in SouthEastern Nigeria, Oxford, U.K.: Clarendon Press, 1978.

Oliver, Roland (ed.), The Dawn of African History, London: Oxford University Press, 1961.

— (ed.), The Middle Age of African History, London: Oxford University Press, 1967. In the Realms of Gold: Pioneering in African History, London: Frank Cass, 1997.

Peres, D. (ed.), Cadamosto, Viagens de Luis de Cadamosto e de Pedro de Sintra, (1463), Lisbon: Academia Portuguesa da História, 1948.

— (ed.), De Lemos Coelho, F., Duas descrições seiscentistas de Guiné, (1669, 1684), Lisbon: Academia Portuguesa de História 1953.

Peterson, John Eric, Province of Freedom: A History of Sierra Leone, 1787-1870, London, Faber and Faber, 1969.

Phillips, Clifton J., Protestant America and the Pagan World: The First Half Century of the American Board of Commissioners for Foreign Missions, 1810- 1860, with a 
foreword by John Fairbank, Cambridge, Massachusetts: East Asian Research Center, Harvard University, 1969.

Phillips, Cyril. H., The School of Oriental \& African Studies, University of London 1917-1967, London: School of Oriental \& African Studies, University of London, 1967.

Roberts, A. D. (ed.), Cambridge History of Africa, Volume 7, 1905 to 1940, Cambridge, U.K.: Cambridge University Press, 1986.

Rodney, Walter, A History of the Upper Guinea Coast, 1545-1800, Oxford, U.K.: Oxford University Press, 1970.

— How Europe Underdeveloped Africa, London: Bogle-L'ouverture Publications, 1972.

Ryder, A. F. C., Benin and the Europeans, 1485-1897, London: Longmans, 1969.

Scanlon, David G., (ed.), Traditions of African Education, New York: Bureau of Publications Teachers College, Columbia University, 1964.

Schlenker, C. F., A Collection of Temne Traditions, Fables and Proverbs, London: Christian Missionary Society, 1861.

— An English Temne Dictionary, London, Christian Missionary Society, 1882.

Schön, J. F., A Grammer of the Mende Language, London: Society for Promoting Christian Knowledge, 1882.

Schön, J. F., and. Crowther, S. A., Journals, London: Society for Promoting Christian Knowledge, 1842.

Sibthorpe, A. B. C., The History of Sierra Leone, with an introduction by Robert W. July, 1868, fourth edition, London: Frank Cass, 1970.

Silveira, L. (ed.), Alvares d'Almada, A., Tratado breve dos rios de Guiné, (1594), Lisbon, 1946.

Sumner, A. T., A Handbook of the Temne Language, Freetown, Sierra Leone: Government Printing Office, 1917.

- A Handbook of the Sherbro Language, London: Crown Agents for the Colonies for the Government of Sierra Leone, 1921.

Trevor-Roper, Hugh, The Rise of Christian Europe, London: Thames and Hudson, 1965.

Vansina, Jan, De La Tradition Orale: Essai de Méthode Historique, Tervuren: Musee Royal de l'Afrique Central, 1961.

L L'evolution du royaume rwanda des origines á 1900, Brussels: Académie Royale des Sciences d'Outre-mer, 1962.

_ Geschiedenis van de Kuba van ongeveer 1500 tot 1904, Tervuren: Musée Royal de l'Afrique centrale, 1963. (Vansina's unaltered published Ph.D. text).

— Le royaume Kuba, Tervuren: Annales du Muśee Royal de l'Afrique Centrale, Sciences Humaines, 1964.

_ Oral Tradition: A Study in Historical Methodology (Trans by H.M. Wright). London: Routledge and Kegan Paul, 1965.

- Kingdoms of the Savanna, Madison, Wisconsin: University of Wisconsin Press, 1966.

— The Children of Woot: A History of the Kuba Peoples, Madison, Wisconsin: University of Wisconsin Press, 1978.

_ Oral Tradition as History, Madison, Wisconsin: University of Wisconsin Press, 1985.

_ Living with Africa, Madison, Wisconsin: The University of Wisconsin Press, 1994. 
How Societies Are Born: Governance in West Central Africa Before 1600, Charlottesville, Virginia: University of Virginia Press, 2004.

Vansina, Jan, R. Mauny, and L.V. Thomas (eds.), The Historian in Tropical Africa: Studies Presented and Discussed at the Fourth International African Seminar at the University of Dakar, Senegal 1961, London: Oxford University Press, 1964.

Wallbank, T. Walter., India in the New Era, Chicago: Scott Foresman and Co., 1951.

West, Richard, Back to Africa: A History of Sierra Leone and Liberia, New York: Holt, Rinehart and Winston, 1970.

Williams, Geoffrey J., A Bibliography of Sierra Leone, 1925-1967, New York Africana Publishing Corp., 1971.

\section{Websites}

Achimota School, http://www.ac2010.org/about_achimota.html, last accessed 3 December 2007.

Achimota School, 'Sir Frederick Gordon Guggisberg', http://www.ac2010.org/guggisberg_biography.html, last accessed 3 December 2007.

African Studies Association, 'Melville J. Herskovits Award Winners', http://www.africanstudies.org/?page=herskovitz_award_winners, last accessed 29 October 2008.

Aim 25, Archives in London and the M25 area, 'School of Oriental and African Studies Archives', http://www.aim25.ac.uk/cgi-bin/search2?coll_id=2951\&inst_id=19, last accessed 21 August 2007.

Aim 25, Archives in London and the M25 area, Institute of Commonwealth Studies, 'Crowder, Michael (1934-1988)', http://www.aim25.ac.uk/cgibin/search2?coll_id=4931\&inst_id=16, last accessed 13 May 2008.

Carnegie Corporation of New York, http://www.carnegie.org/sub/about/mission.html, accessed 14 October 2008.

Church Missionary Society Britain, 'A Brief History of CMS', http://www.cmsuk.org/Whoweare/History/tabid/181/Default.aspx, last accessed 12 September 2007.

Fletcher School, Tufts University, Multilaterals Project, 'Covenant of the League of Nations, Article 22 the, signed on 28 June 1919',

http://fletcher.tufts.edu/multi/www/league-covenant.html, last accessed 10 November 2007.

Government of Canada, Canada Research Chairs, Chairholders, 'Paul E. Lovejoy', http://www.chairs.gc.ca/web/chairholders/viewprofile_e.asp?id=779, last accessed 18 November 2008.

History Compass, 'David Henige', http://www.blackwellcompass.com/subject/history/article_biog?article_id=hico_articles_bpl490, last accessed 3 November 2008.

Institute of International Studies, Faculty of Social Sciences, Charles University, 'Documents of American History II, M2010, 1950s: National Defense Education Act of 1958', http://tucnak.fsv.cuni.cz/ calda/Documents/1950s/Education_58.html, last accessed 17 October 2008. 
Liverpool Medical History Society, 'Obituary Professor Paul E. H. Hair (1926-2001)', Medical Historian, Number 12, 2001, pp. 53-54, www.lmi.org.uk/medical_society/12/12Obituary.pdf, last accessed 13 May 2008.

MUNDAS, online guide to Missionary Societies in the United Kingdom, School of Oriental and African Studies, University of London, 'London Missionary Society', http://www.mundus.ac.uk/cats/4/251.htm, last accessed 27 August 2007.

National University of Lesotho, 'Historical Note', http://www.nul.ls/about/history.htm, last accessed 19 August 2007.

Oxford Dictionary of National Biography, P. J. L. Frankl, 'Werner, Alice (1859-1935)', Oxford University Press, 2004; online edition, May 2006, http://www.oxforddnb.com/view/article/38117, last accessed 8 January 2008.

Oxford Dictionary of National Biography, Kathleen Bliss and Andrew Porter, 'Oldham, Joseph Houldsworth (1874-1969)', Oxford University Press, 2004; online edition, May 2007, http://www.oxforddnb.com/view/article/35301, last accessed 16 November 2008.

Rutgers, The State University of New Jersey, African Studies Association Awards, 'Melville J. Herskovits Award Winners'

http://www.rci.rutgers.edu/ callasa/asa_herskovitzawardwinners.html, last accessed 1 December 2008.

Sierra Leone Grammar School Alumni in the United Kingdom, C. Magbaily Fyle, 'The Grammar School and Education in Sierra Leone, 1845-1942', http://www.regentonians.org/templates/slgs.asp?articleid=2\&zoneid=1, last accessed 10 October 2007.

Sierra Leone Web, 'Bibliography', http://www.sierra-leone.org/bibliography.html, last accessed 1 October 2007.

Sierra Leone Web, 'Heroes', http://www.sierra-leone.org/heroes3.html, accessed 25 October 2007.

United Nations, Official Documents System of the United Nations, 'The Declaration on Granting Independence to Colonial Countries and Peoples', http://daccessdds.un.org/doc/RESOLUTION/GEN/NR0/152/88/IMG/NR015288.p df?OpenElement, last accessed 10 April 2007.

University of Hull, 'Professor David Richardson', http://www.hull.ac.uk/history/Staff/Academic/David_Richardson.html, last accessed 18 November 2008.

University of Hull, Wilberforce Institute for the Study of Slavery and Emancipation, 'Professor Paul E. Lovejoy', http://www.hull.ac.uk/wise/People/Honoraryfellows/Lovejoy/index.html, last accessed 18 November 2008.

University of Hull, Wilberforce Institute for the study of Slavery and Emancipation, http://www.hull.ac.uk/wise/index.html, last accessed 18 November 2008.

University of Leipzig, 'Employees, Dr. Adam Jones, Professor of History and Culture in Africa', http://translate.google.co.nz/translate?hl=en\&sl=de\&u=http://www.unileipzig.de $/ \sim$ afrika $/ \&$ sa $=X \& o i=$ translate\&resnum $=1 \& \mathrm{ct}=$ result $\&$ prev $=/ \mathrm{search} \% 3 \mathrm{Fq}$ $\% 3 \mathrm{DInstitut} \% 2 \mathrm{Bf} \% 25 \mathrm{C} 3 \% 25 \mathrm{BCr} \% 2 \mathrm{BAfrikanistik} \% 26 \mathrm{hl} \% 3 \mathrm{Den} \% 26 \mathrm{sa} \% 3 \mathrm{DG}$, last accessed 13 May 2008.

University of Wisconsin, 'African Studies Programme', http://africa.wisc.edu/, last accessed 1 November 2008.

University of Wisconsin, 'African Languages and Literature Department', http://african.lss.wisc.edu/languages/why_page.htm, last accessed 31 October 2008. 
Voyages: The Trans-Atlantic Slave Trade Database, 'Estimates', http://www.slavevoyages.org/tast/assessment/estimates.faces, last accessed 28 November 2008.

York University, 'Paul E Lovejoy, Short Curriculum Vitae', http://www.yorku.ca/uhistory/faculty/cv/lovejoy.htm, last accessed 18 November 2008 .

\section{Personal Correspondence from African Historians}

Associate Professor Janet Ewald, Duke University, 6 November 2008.

Professor Ruth Finnegan, The Open University, 30 May 2008.

Dr. David Henige, University of Wisconsin-Madison, 21 May and 20 August 2008.

Professor Adam Jones, University of Leipzig, 22 and 23 November 2008.

Professor Robin Law, University of Stirling, 25 August 2008.

Professor David Northrup, Boston College, 23 August 2008.

Professor John K. Thornton, Boston University, 24 August 2008. 